\title{
EVOLUTION AND ENVIRONMENT OF THE EASTERN LINEAR POTTERY CULTURE: A CASE STUDY IN THE SITE OF POLGÁR-PIÓCÁSI-DÜLŐ
}

\author{
EMESE GYÖNGYVÉR NAGY-MAŁGORZATA KACZANOWSKA-JANUSZ K. KOZŁOWSKI- \\ MAGDALENA MOSKAL-DEL HOYO-MARIA LITYŃSKA-ZAJĄC
}

E. Gy. Nagy: Déri Museum, Déri tér 1, H-4026 Debrecen, Hungary. E-mail: nagy.emesegy@gmail.com M. Kaczanowska: Institute of Archaeology, Jagiellonian University, ul. Gołebia 11, PL-31007 Kraków, Poland. E-mail:malgorzatakacz@wp.pl

J. K. Kozłowski: Institute of Archaeology, Jagiellonian University, ul. Gołebia 11, PL-31007 Kraków, Poland. E-mail: janusz.kozlowski@uj.edu.pl

M. Moskal-del Hoyo: W. Szafer Institute of Botany, Polish Academy of Sciences, Lubicz 46, PL-31-512 Kraków, Poland. E-mail:m.moskal@botany.pl

M. Lityńska-Zając: Institute of Archaeology and Ethnology, Polish Academy of Sciences, ul. Sławkowska 17, PL-31016 Kraków, Poland. E-mail: marialitynska@gazeta.pl

\begin{abstract}
A salvage excavation preceding a major investment project was conducted in 2006-2007, during which associated settlement features of a Middle Neolithic, Eastern Linear Pottery Culture (Alföld Linearbandkeramik - ALBK) were uncovered in an area called Piócási-düló on the eastern outskirts of Polgár. The features of the ALBK settlement date from two periods. The cluster of multi-functional pits yielding a rich assortment of finds, the handful of post-holes and an unusual ritual well found in the southern part of the investigated area formed one unit from the earliest phase of the Middle Neolithic (ALBK I). The settlement's other occupation can be assigned to the late phase of the Middle Neolithic (ALBK IV). Five houseplans representing the remains of timber-framed buildings outlined a distinct area with three multi-functional pits. Associated with the above features were 8 burials.

The preliminary archaeobotanical results from Polgár-Piócási-dülő are based on the plant material found within the sediments of 11 archaeological structures, which mainly represent pits and a welI. It can be stated that the natural environment offered habitats in which oak trees dominated in the local vegetation, forming floodplain forests and wooded steppes. They also provided food in the form of fruits and formed an optimal habitat for domestic animals. Arable fields were probably also established in the vicinity of the settlements, suggested by findings of macroscopic plant remains that represented cultivated species.

In both settlement phases lithic production activities are manifested both by the local on-site lithic production and - most importantly - by the presence of imported, mainly mesolocal, raw materials that point to contacts with deposit areas, or off-site preliminary working of obsidian and limnoquartzites. The kit of harvesting tools and a large number of grinding stones - especially in the younger phase - for the preparation of plant food suggest a major role of plant cultivation.
\end{abstract}

Keywords: Eastern Linear Pottery Culture, Polgár island, Middle Neolithic settlement, lithic analyses, anthracology

\section{INTRODUCTION}

A salvage excavation preceding a major investment project was conducted in 2006-2007, during which associated settlement features of a Middle Neolithic settlement, as well as the features of other archaeological periods were uncovered in an area called Piócási-dülő on the eastern outskirts of Polgár (Fig. 1). ${ }^{1}$

The site lies in the area known in the archaeological literature as Polgár island, which has been intensively investigated during the past few decades. ${ }^{2}$ Consistent patterns can be noted in the location of the fairly densely spaced archaeological sites from $5500 \mathrm{BC}$ to the early medieval period ( $13^{\text {th }}$ century) in the area whose boundaries could be precisely determined based on its hydrology, terrain and other ecological factors. There are two prehistoric sites in the region whose investigation, begun in the 1950s, has been keenly followed by Hungarian and European 

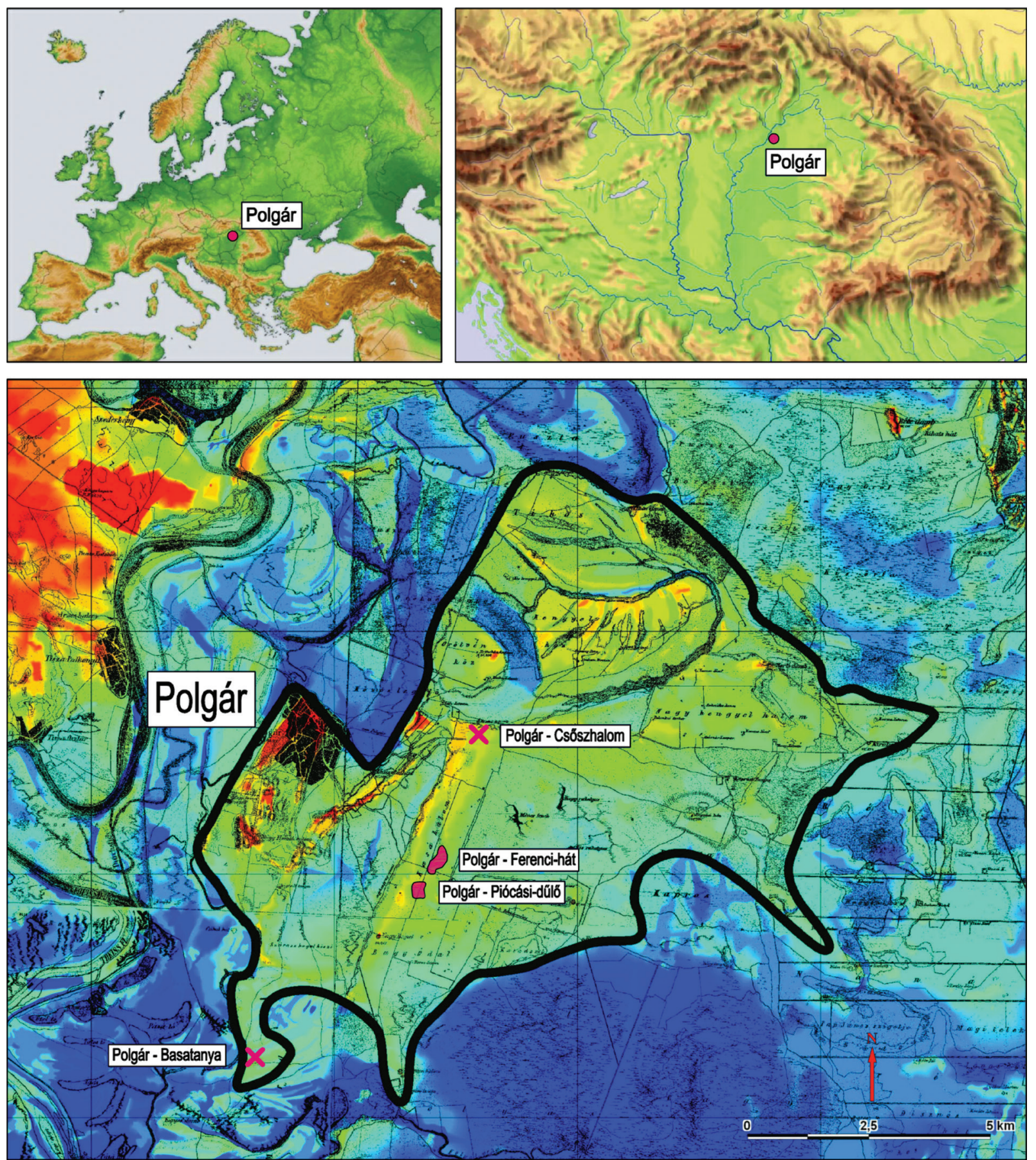

Fig. 1. The geographical location of Polgár-Piócási-dülő

prehistoric research. Both sites occupy a prominent place in prehistoric studies. One is Polgár-Basatanya in the southern part of Polgár island, where an Early and Middle Copper Age cemetery was uncovered, ${ }^{3}$ The other is the Late Neolithic tell settlement at Polgár-Csőszhalom in the region's north-eastern part. ${ }^{4}$ 
The slightly prominent buff where the region's largest Middle Neolithic settlement has been identified lies half-way between the two internationally renowned sites. ${ }^{5}$ The excavations at Polgár-Ferenci-hát brought to light the remains of an extensive settlement of the Eastern Linear Pottery Culture (or Alföld Linearbandkeramik - ALBK) and shed light on the settlement's elaborate layout, made up of a central settlement area enclosed by a ditch and a more loosely occupied extensive peripheral area. ${ }^{6}$ The burnt daub fragments and the profusion of vessels adorned with incised patterns recovered from the densely spaced archaeological features in the settlement centre indicated that this part of the settlement had functioned as a ceremonial area, the setting of both sacral activities and other everyday ritual actions. A relatively high number of ALBK features were uncovered in the settlement part lying beyond the enclosure. The typical timber-framed buildings and the associated multi-functional pit complexes reflected the area's division into household-based units. The use of these domestic spaces was complemented by an intricate system of small burial places with one or more graves. Several interesting phenomena could be noted within the grave clusters such as bodies deposited in refuse pits, headless bodies and burials with an array of unusual grave goods (for example, some burials contained obsidian cores, while in another, large Spondylus bracelets accompanied the burial of a child). ${ }^{7}$ The density of settlement features declined in the areas lying farther from the settlement's centre. The boundary of the site could not be clearly identified.

This "fluid" boundary created a special relation with the site at Piócási-dülö, which lies no more than a few hundred metres south of the Ferenci-hát settlement, in the southern corner of the same buff. The spatial relation between the two sites could not be conclusively clarified owing to the modern road and railway line running between the two. The most compelling argument for the connectedness of the two sites is their chronology: both sites yielded finds of the early (ALBK I) and late (ALBK IV) phase of the Middle Neolithic, although the overwhelming majority of the settlement features could be assigned to the late phase (Esztár and Tiszadob groups, Bükk Culture). At the Ferenczi-hát settlement, the greater part of the occupied area was covered with the settlement features of the late phase, although features of the early phase could also be documented in a relatively well-definable area. The three superimposed layers of the central tell-like settlement part ringed by the enclosure represent the occupation of both periods. ${ }^{8}$ The lowermost layer can be definitely correlated with the ALBK I period (earlier labelled Szatmár II). This is overlain by a humus layer yielding sporadic finds of the ALBK II-III period, indicating a temporal continuity, while the uppermost layer represents the occupation deposit of the late phase with a high concentration of settlement features and artefactual material. The two main occupation periods in the settlement's life are thus clearly separated in terms of their relative chronology. At the same time, there is indirect evidence for genetic relation between the two occupations, indicated by both spatial overlaps and spatial discreteness relative to each other, the intense traces of burning in both periods and the presence of pits containing a rich inventory of lithic finds from both periods.

While there was no comparable stratified central settlement part at the Piócási-dülő site, the settlement features of the early occupation period are similarly restricted to spatially discrete areas that are surrounded by the features of the late phase. Only in the case of a few pits did we observe a superposition. The density of the settlement features observed in the settlement's central part declined visibly towards the Ferenci-hát site (activity pits with open spaces around them at the settlement's edge), suggesting that the Piócási-dülő site represented a separate settlement which nevertheless shared numerous similarities with the Ferenci-hát settlement regarding both its chronological position and its other traits. The relationship between the two can best be described as one between a central settlement and its satellite. The Ferenci-hát site was an extensive settlement with a "tell-like" core ringed by an enclosure, ${ }^{9}$ which was surrounded by satellite settlements, ${ }^{10}$ one of which was the Piócási-düló site.

The Piócási-dủlő site lies on the south-eastern outskirts of Polgár (Fig. 2). The area's one-time geomorphological features can still be seen, despite the various modern installations (railway, motorway, industrial park, shopping centre, petrol station) owing to the proximity of the town. ${ }^{11}$ The barely prominent ridges are enclosed by

${ }^{5}$ RACZKY-ANDERS 2009.

${ }^{6}$ RACZKY-ANDERS 2012; WhitTLE et al. 2013.

${ }^{7}$ RACZKY 2004.

${ }^{8}$ RACZKY-ANDERS 2009, 43-45.

${ }^{9}$ As the forerunner of the later Tisza Culture, the Szakálhát Culture of the ALBK 4 phase marked by a number of phenomena that became the hallmark of the later tell cultures. These are sometimes labelled "incipient tells" (MAKKAY 1982, 108.) The lowermost occu- pation level of the Csőszhalom tell settlement was defined by the pits dated tothe ALBK IV period (RACZKY et al. 1994).

${ }^{10}$ Intensive fieldwork in the micro-region known as the Polgár island during the past few decades led to the identification of several Middle Neolithic settlements, enabling the study of the relations between them (FüZESI 2007; RACZKY-ANDERS 2009).

${ }^{11}$ SÜMEGI 2003. 


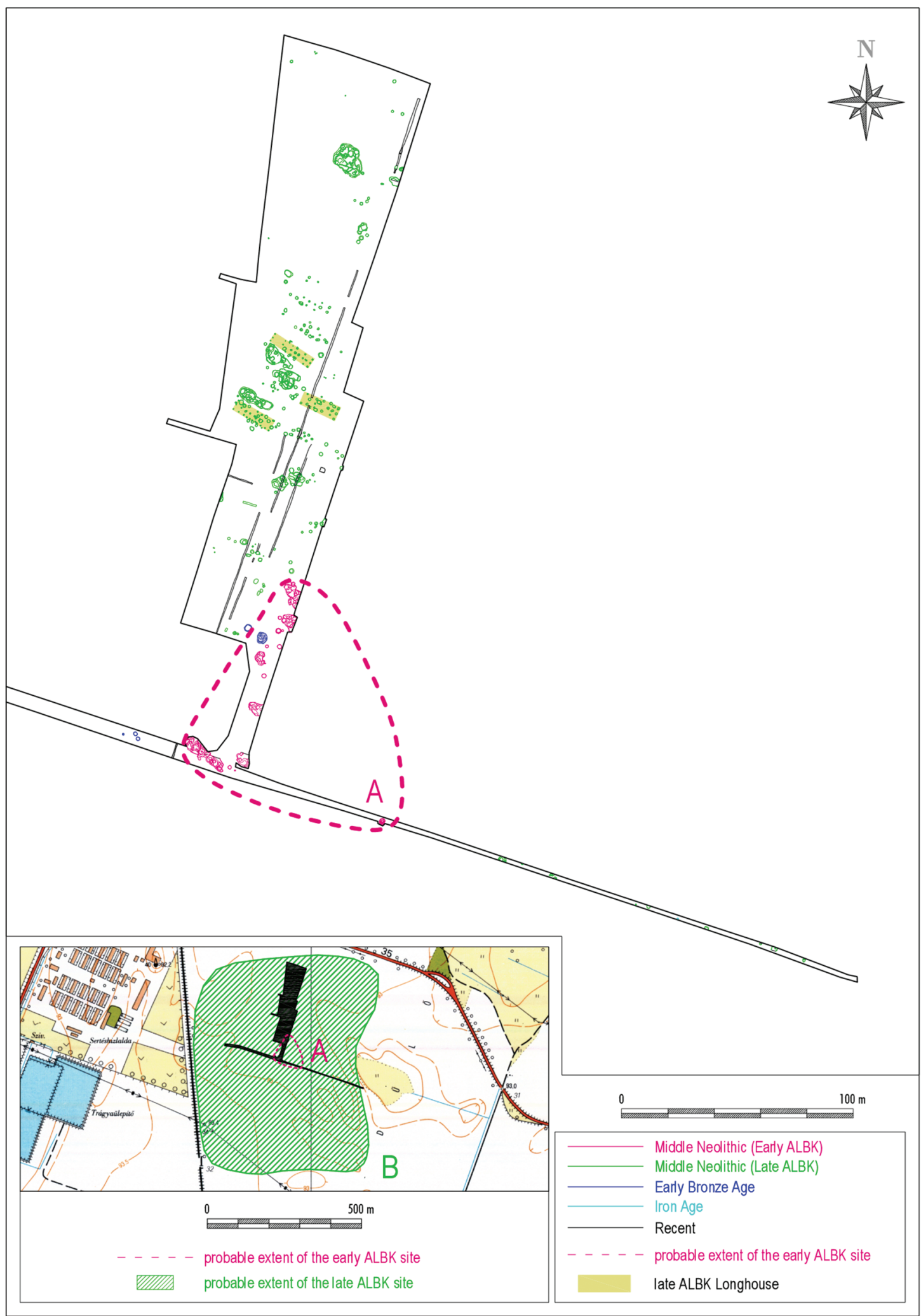

Fig. 2. The excavated area of Polgár-Piócási-dủlő 
the channels of one-time watercourses. Although appearing as perfectly level land from afar, the traces and remnants of the earlier hummocks, waterlogged soils and vegetation can still be distinguished from the form and soil level of the tongues projecting from the ridges.

In terms of the broader geographic setting, the area is part of the Borsod floodplain of the Middle Tisza region. The landscape was predominantly moulded by the shifting channels of the palaeo-Tisza and its countless side-branches. Owing to the stabilising role of the floodplain vegetation, wind played a secondary role in sculpting the land. The yellow, loessy soil flanking the river and the stream channels resembled a hard, plateau-like formation, which provided a more favourable and more stable foundation for human occupation during the past ten thousand years of the Holocene than the dissected, dune-covered landscapes shaped by the wind such as the Nyírség for example.

The presence of an ALBK settlement could be identified during the preliminary surface surveys. ${ }^{12} \mathrm{O}$ wing to intensive cultivation and other factors, the site's exact size and its internal layout could only be determined to some extent. The excavation trenches conforming to the investor's planned construction area yielded important new details. We found that the western boundary of the ALBK settlement could be more or less accurately determined in the area investigated with the excavation trenches, despite the fact that scatters of surface finds could found some 60-80 m farther away. Two more intensively occupied areas could be distinguished in the excavated area. The central and peripheral units of the prehistoric community's use of space alternated with each other, conforming to the potentials of the landscape.

We identified various settlement features of an ALBK settlement in the roughly one and a half hectares large excavated area, as well as a handful of features from other archaeological periods (Table 1). The western part of the investigated area was devoid of features on the testimony of the north-south long trench and the west-east trench traversing it. The archaeological features were concentrated in the virtually contiguous areas. The remains of the timber-framed buildings and the associated multi-functional large pits reflected a consistent spatial patterning and represented the relative centres of the prehistoric settlement. Their location and the archaeological features identified in the west-east trench suggested that the central part of the ALBK settlement had continued for some

Table 1. Polgár-Piócási-dülő. Summary of the excavated archaeological features

\begin{tabular}{|l|c|c|c|c|}
\hline Type of object & Middle Neolithic & Early Bronze Age & Iron Age & Recent \\
\hline Pit & 153 & 5 & 1 & 1 \\
\hline Post hole & 99 & - & - & - \\
\hline ALBK house (longhouse) & 2 & - & - & - \\
\hline Complementary building & 1 & - & - & - \\
\hline Well & 7 & - & - & - \\
\hline Grave & 8 & - & - & - \\
\hline Dog skeleton & 2 & - & - & - \\
\hline Ditch & - & - & 1 & 2 \\
\hline Total & 272 & 5 & 2 & 2 \\
\hline
\end{tabular}

80-120 m eastward. The peripheral features (open-air workshop pits, wells, rows of posts) apparently lay in the area east of the investigated settlement part, and similar features lay north and south of the opened trenches, although with a contrary tendency. In the south, we found large pit complexes rich in finds. The intensively occupied settlement part had extended for at least another $40-50 \mathrm{~m}$, conforming to the terrain conditions. In contrast, we found that the archaeological features became sparser towards the north. The peripheral workshop pits and the large open areas most likely mark the settlement's boundary. The uniqueness of this boundary area is that it coincides with the southern periphery and boundary of the large central ALBK settlement at Ferenci-hát. The study of the precise nature of the relation between the two settlements is virtually impossible because this area cannot be investigated owing to the modern road and railway installations covering the area.

${ }^{12}$ Dani-Nagy 2008. 


\section{ENVIRONMENTAL CONDITIONS}

Polgár-Piócási-dülő is located in the Borsod Plain in the Middle Tisza Floodplain. ${ }^{13}$ The settlement occupies a small elevation and during the Neolithic this area was probably situated close to the former bed of the Tisza river. ${ }^{14}$ The area of the archaeological site forms part of the loess-covered lag-surface, which developed on the alluvium of the Tisza river at the end of the Pleistocene ( $c a .15,000 \mathrm{BP})$ and the beginning of the Holocene periods. ${ }^{15}$ The Neolithic occupation can be correlated to the Atlantic period in the European Holocene Blytt-Sernander subdivision, ${ }^{16}$ which has previously been considered much warmer and wetter than the one existing at the present time. ${ }^{17}$ However, recent studies have suggested that in the Great Hungarian Plain, climatic conditions could become warmer and drier after $8300 \mathrm{cal}$. BP. ${ }^{18}$ During the Neolithic, many settlements in this region were located along the Tisza river and its tributaries, which with its diverse habitats, the ideal soil conditions for cultivation and the permanent access to water must have provided an excellent environment for different subsistence strategies. ${ }^{19}$

This is a lowland region with moderately continental climate and an average annual temperature of $9.5-11{ }^{\circ} \mathrm{C}$. The average annual precipitation is between 500 and $600 \mathrm{~mm} .{ }^{20}$ The main zonal vegetation is steppe forest, which developed due to an at least one month long drought period during the summer. ${ }^{21}$ This formation is represented by continental and sub-Mediterranean forest-steppes with different oak species as major components. ${ }^{22}$ In the Tisza river region, the natural woodland vegetation is only found in the form of patches of forest communities. ${ }^{23}$ Along the valley of the Tisza river, the riparian forests developed, which include willow-poplar alluvial forests and alluvial oak-ash-elm forests. ${ }^{24}$

\section{ARCHAEOBOTANY}

Macroscopic plant remains found at archaeological sites provide significant palaeoethnographic and palaeoecological information since they increase the knowledge about plant resources used by people in the past, contribute to the history of local flora and are indicative of the relationship between people and their environment. The plant macro-remains represent cultivated and wild plants. The former offer evidence of ancient diet and may reveal how crop husbandry was practiced in the past, while the latter correspond to intentionally gathered plants such as wild fruits and those that appeared accidentally in the settlements such as weeds. ${ }^{25}$ Remains of wood are frequently found among wild plants, and are preserved in the form of charcoal. This material offers evidence on different uses of wood, a very important material employed for construction, preparation of tools and other kinds of objects. Their taxonomic identification permits one to establish the criteria of wood selection and indicates the diverse strategies of forest management. In anthracology, charcoal found in such a context is called "concentrated charcoal". In contrast, charcoal remains of firewood that was collected over a longer period of time are classified as "dispersed charcoal". This type of assemblage is usually representative of the environment since it reflects the woody flora of past forest formations relatively well. This assumption does not only concerns the qualitative data, but also general quantitative relationships between different taxa, in terms of which the indication of dominant or subordinate species is a key factor. ${ }^{26}$

The macroscopic plant material came from soil samples collected during the archaeological excavations. About 380 litres of sediments were floated and water-sieved with the help of meshes with diameters of 0.2 and

${ }^{13}$ MAGYARI 2011, fig. 5.

${ }^{14}$ SÜMEGi et al. 2005; WhitTLE et al. 2013.

15 SÜMEGI et al. 2005; SÜMEGI 2013.

${ }^{16}$ ROBERTS 1998.

17 JÁRAI-KOMLÓDI 1968; JÁRAI-KOMLÓDI 2003.

${ }^{18}$ MAGYARI et al. 2010.

${ }^{19}$ GARDNER 2005; GILlings 2007; RACZKY et al. 2012; GyUlai 2013

${ }^{20}$ PÉCSI-SÁRFALVI 1964; PÉCSI et al. 1989.

${ }^{21}$ ZÓLYOMI-FEKETE 1994; DONIŢA-KARAMYŠEVA 2004; Molnár et al. 2012.
22 DONIŢA-KARAMYŠEVA 2004; BÖLÖNI et al. 2011.

${ }^{23}$ SÜMEGI-Molnár 2007; Molnár et al. 2012.

24 BÖLÖNI et al. 2008; BÖLÖNI et al. 2011. 2005, 23-24

${ }^{25}$ PEARSALL 2000, 1-3; LityŃSKA-ZAJĄC-WASYLIKOWA

${ }^{26}$ Chabal 1988, 193-196, 214; Chabal 1992, 215-220; Chabal 1997, 58-61; Badal 1992, 170-187; HeinZ-ThiÉBault 1998, 57; THÉRY-PARISOT 2001, 26-32; NTINOU 2002, 18-23; ASOUTIAustin 2005, 3-4; CARRIÓN 2005, 31-35; LITYŃSKA-ZAJĄC-WASYLIKOWA 2005, 275, 279; MOSKAL-DEL HoYo 2013. 
$1.0 \mathrm{~mm}$. This work began in the field in Polgár, but it had to continue in the laboratory of the W. Szafer Institute of Botany of the Polish Academy of Sciences due to the high clay content in the sediments that hampered their dispersion in water. Afterwards, the sediments were soaked in boiling water and left for 24 hours. This procedure permitted a better recovery of plant remains. Fruits, seeds, charcoal and other different vegetative parts of plants were found. A few samples of daub with plant imprints were also analyzed. For the taxonomical identifications of plants, a stereomicroscope with 2.5 to 50x magnification was used. Fruits and seeds were identified on the basis of their morphological characteristics and by comparison with present-day reference collections from the Archaeobotanical Laboratory of the Institute of Archaeology and Ethnology of the Polish Academy of Sciences and the Department of Palaeobotany of the W. Szafer Institute of Botany of the Polish Academy of Sciences. Botanical analyses were also based on the study of the specialized literature. ${ }^{27}$ For the analysis of wood anatomy, a reflected light microscope with higher magnifications of 100, 200 and 500x was employed. Each charcoal fragment was broken along the three anatomical sections of wood, namely transverse, longitudinal radial and longitudinal tangential. Taxonomical identifications were made by comparing the unknown specimens with modern wood collections and by examining the specialized literature. ${ }^{28}$ The rank of identification (species, genera, family, etc.) depends on the size, the anatomical characteristics of the wood, and the state of preservation of the charcoal fragments. ${ }^{29}$ However, the identification of species in Central Europe is mainly determined by the existence of only one species in the local flora. ${ }^{30}$ The only taxon identified to the species level was Pinus sylvestris (Scots pine), but this was based on ecological requirements and present-day distribution of Pinus species in lowland areas, ${ }^{31}$ since the anatomical characteristics of this taxon, including the presence of fenestriform pits, only indicate that a specimen represents the subgenus Pinus. ${ }^{32}$

The preliminary results from Polgár-Piócási-dülő are based on the plant material found within the sediments of 11 archaeological structures, which mainly represent pits, but there was also one structure identified as a well (feature 132) (Table 2). In these samples, the plant material appeared together with fragments of pottery and chipped stone artefacts, uncharred animal and fish bones along with mollusc remnants. The latter group was especially abundant in pit 9, while the faunal remains were more frequent in features 65 and 132. Therefore, it is possible that they were associated to a waste context. Taking into consideration the volume of the sediment that was floated, there is a rather low number of specimens found in this settlement. However, the scarceness of plant remains despite the employment of flotation of rather large quantities of soil samples is commonly observed at Neolithic settlements in Hungary. This could imply that plant cultivation was still on a modest scale, ${ }^{33}$ but it can also be related to depositional processes, the character of the archaeological features or the modest chance to find carbonized plants. The macroscopic plant remains were preserved as charred and uncharred specimens. In archaeobotany, it is commonly assumed that only the charred remains are related to the archaeological context, while uncharred ones are usually considered a younger admixture. This observation especially concerns the archaeological sites situated in dry deposits, meaning that they were not waterlogged. However, it can be more difficult to estimate the chronology of plants coming from wells or other structures that could reach the level of groundwater. ${ }^{34}$ The uncharred material came from wild herbaceous plants and the needles of Pinus sylvestris (Table 2). These kinds of remains are usually not taken into consideration during the interpretation of archaeobotanical samples, but it is interesting that all of the uncharred species were also documented in charred material. Plant remnants were generally well preserved, with the exceptions of cereal grains (caryopsis, Table 2). The charcoals were also in a good state of preservation, although non-identifiable fragments and those identified only as broad-leaved plants also occurred.

Among charred plants and plant imprints found in pieces of daub at Polgár-Piócási-dülő, the remains of cultivated and wild plants were documented (Table 2). The cereals were mainly preserved as fragments of caryopsis, and although their morphology in many cases may resemble ancient wheat species, such as emmer wheat (Triticum dicoccon) and einkorn wheat (Triticum monococcum) (Fig. 3.1), it was more appropriate to include them in the group of undetermined Cerealia. The only specimen unearthed in a better state of preservation may be classified as emmer wheat (Triticum dicoccon). Other cultivated plants were represented by barley (Hordeum vulgare) and lentil

\footnotetext{
${ }^{27}$ KOWAL 1953; DÖRTER 1968; KowAL-RUdNICKA-STERNOWA 1969; KULPA 1974; RYMKIEWICZ 1979; FALKOWSKI 1982; CAPPERS et al. 2006; CAPPERS et al. 2009.

${ }^{28}$ ESAu 1973; SchweIngruber 1982; SchweIngRuber 1990; HEJNOWICZ 2002.

${ }^{29}$ SCHWEINGRUBER 1982
}

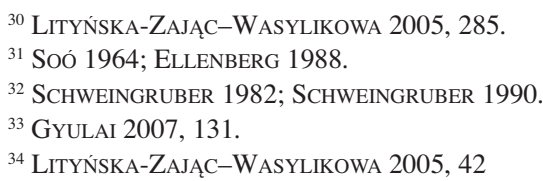


(Lens culinaris). The former was found in the form of a triplet impressed in daub, while the latter appeared as a charred seed (Table 2). It is possible that other seeds identified as Fabaceae could represent this leguminous plant. On the basis of the archaebotanical analysis, it is possible to confirm that cultivated species formed part of the diet of the Neolithic inhabitants of the settlement, but it is difficult to describe ancient crop husbandry. In the Carpathian Basin, the evidence of agrarian practices was detected in the settlements of the first Neolithic groups, which represented the Körös-Starčevo Culture. In general, this region played an important role in the spread of domesticated plants from the areas of the Fertile Crescent to other parts of Central Europe. ${ }^{35}$ In the Carpathian Basin, the most frequent cereal species cultivated in the Early Neolithic were hulled emmer and einkorn wheat as well as hulled and naked barley. There was also evidence for the use of other cultivated plants, including cereals (e.g. spelt wheat Triticum spelta, common wheat Triticum aestivum, common millet Panicum miliaceum) and leguminous plants such as lentil and pea (Pisum sativum). ${ }^{36}$ In the Middle Neolithic, the same spectrum of species was documented and it seemed that ancient hulled wheat together with barley were still dominating crops. ${ }^{37}$ In the area of Polgár, at sites dated to the Middle Neolithic, especially in Polgár-Ferenci-hát, a dominance of barley was documented. This cereal was found as six-rowed (Hordeum vulgare ssp. hexastichum) as well as two-rowed naked barley (Hordeum vulgare ssp. distichum Zoh. var. nudum). ${ }^{38}$ Also, hulled wheat species, such as emmer, einkorn and spelt (Triticum aestivum ssp. spelta) were among the most frequently found cereals, while other species were sporadically found. The most interesting findings were the infrequent occurences of millet (Panicum miliaceum), rye (Secale cereale) and freethreshing naked wheat (Triticum parvicoccum). ${ }^{39}$

Hulled wheat species were the most frequent cereals cultivated in the area of the Balkans and in Southeast Europe, where the oldest European Neolithic cultures appeared. ${ }^{40}$ Emmer and einkorn wheats were also among the oldest cultivated plants in other regions in which the Neolithic Linear Pottery culture developed. ${ }^{41}$ Both aforementioned wheat species grew most likely on the same fields since they exhibit similar habitat requirements. On the other hand, although barley requires similar environmental conditions, it was probably sown in different fields than wheat as its grains ripen during a different time period. ${ }^{42}$ Among eight species of herbaceous plants, seeds of white goosefoot (Chenopodium type album) were predominant and were also more ubiquitous since they appeared in three pits (Fig. 3.2). The rest of the taxa were found in a singular pit and only a few specimens were present. The taxonomic list included maple leaved goosefoot (Chenopodium hybridum), barnyard grass (Echinochloa crus-galli), black-bindweed (Fallopia convolvulus), common knotgrass (Polygonum aviculare), redshank (Polygonum persicaria, Polygonum minus), and common sorrel (Rumex acetosa) (Table 2; Fig. 3.3-6). All these wild herbaceous plants are nowadays typical field and ruderal plants, associated with anthropogenic vegetation. They are mostly annual plants. However, it is very difficult to confirm that they mainly represent weeds since they were not found in contexts directly associated with cereal remains since no storage pits were discovered. On the other hand, archaeobotanical studies of wild plants found in storage structures containing cereal grains from other Neolithic settlements clearly demonstrated that these weeds grew in the cereal fields. This especially concerns white goosefoot, barnyard, black-bindweed and different Polygonum species. ${ }^{43}$ Furthermore, Chenopodium album, Echinochloa crus-galli and Fallopia convolvulus are nowadays typically related to the cultivation of root-crops, but as demonstrated by the archaeobotanical studies they probably grew first in cereal fields and this could be linked with different techniques of field preparation in the Neolithic. This garden-type cultivation consisted of cereals that were planted by hand, in small groups that subsequently needed hoeing and weeding. ${ }^{44}$ These procedures resemble the ones used for root-crops. The remains of Fallopia convolvulus and Echinochloa crus-galli were found in the PolgárFerenci-hát site, but the latter was very sporadic. ${ }^{45}$

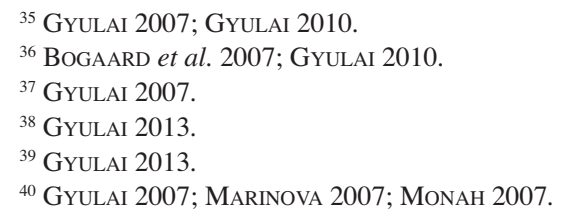

${ }^{41}$ BienieK 2002; BienieK 2007; Hajnalová 2007; JACOMET 2007; KOHLER-SCHNEIDER 2007; LITYŃSKA-ZAJĄC 2007; LiTYŃSKA-ZAJĄC et al. 2008; KREUZ 2007; KREUZ 2010/2012.

${ }^{42}$ LITYŃSKA-ZAJĄC-WASYLIKOWA 2005

${ }^{43}$ LITYŃSKA-ZAJĄC 2005, 147-154.

44 BogaARd 2004; BogAard 2005; LiTYŃSKA-ZAJĄC 2005, 262; KREUZ-SCHÄFER 2011.

${ }^{45}$ GyUlai 2013. 
Table 2. The results of the analysis of macroscopis plant remains from Polgár-Piócási-dülő. Explanations: ch - charred, uch - uncharred.

\begin{tabular}{|c|c|c|c|c|c|c|c|c|c|c|c|c|c|}
\hline \multirow{4}{*}{ Taxa } & \multirow{4}{*}{$\begin{array}{c}\text { state of } \\
\text { preservation }\end{array}$} & \multirow{4}{*}{$\begin{array}{l}\text { type of } \\
\text { remains }\end{array}$} & \multicolumn{11}{|c|}{ Feature } \\
\hline & & & 9 & 30 & 46 & 59 & 65 & 71 & 79 & 87 & 132 & 141 & 148 \\
\hline & & & \multicolumn{11}{|c|}{ Stratigraphic unit } \\
\hline & & & 13 & 36 & 57 & 73 & 96 & 106 & 118 & 127 & 233 & 230 & 222 \\
\hline Hordeum vulgare & imprint & triplet & & & & & & & & 1 & & & \\
\hline Triticum cf. dicoccon & $\mathrm{ch}$ & caryopis & 1 & & & & & & & & & & \\
\hline Cerealia indet. & $\mathrm{ch}$ & caryopis & 42 & 1 & & & & 1 & & 1 & & & \\
\hline Lens culinaris & $\mathrm{ch}$ & seed & & & & & & 1 & & & & & \\
\hline \multirow{2}{*}{ Chenopodium t. album } & $\mathrm{ch}$ & \multirow{2}{*}{ seed } & 11 & & & & & 2 & & 120 & & & \\
\hline & uch & & & 1 & & & & & & & & & \\
\hline Chenopodium hybridum & $\mathrm{ch}$ & seed & 2 & & & & & & & & & & \\
\hline Echinochloa crus-galli & $\mathrm{ch}$ & caryopis & 1 & & & & & & & & & & \\
\hline Fallopia convolvulus & $\mathrm{ch}$ & fruit & 1 & & & & & & & & & & \\
\hline \multirow{2}{*}{ Polygonum aviculare } & $\mathrm{ch}$ & \multirow{2}{*}{ fruit } & 3 & & & & & & & & & & \\
\hline & uch & & & & & & 1 & 1 & & & 1 & 1 & \\
\hline Polygonum persicaria & $\mathrm{ch}$ & fruit & 1 & & & & & & & & & & \\
\hline Polygonyum minus & $\mathrm{ch}$ & fruit & 1 & & & & & & & & & & \\
\hline Rumex acetosa & $\mathrm{ch}$ & fruit & & 1 & & & & & & & & & \\
\hline \multirow{2}{*}{ Chenopodium sp. } & $\mathrm{ch}$ & \multirow{2}{*}{ seed } & & 1 & & & & & & & & & \\
\hline & uch & & & & & & 1 & & & & & & \\
\hline Fabaceae indet. & $\mathrm{ch}$ & seed & 1 & & & & & 1 & & & & & \\
\hline Polygonaceae & $\mathrm{ch}$ & fruit & 1 & & & & & & & & & & \\
\hline Pinus sylvestris & uch & neddle & & & & & & & & & 208 & & \\
\hline \multicolumn{3}{|c|}{ total } & 65 & 4 & & & 2 & 6 & & 122 & 209 & 1 & \\
\hline Pinus t. sylvestris & $\mathrm{ch}$ & charcoal & 17 & & & & & & & & & & \\
\hline Fraxinus sp. & $\mathrm{ch}$ & charcoal & 3 & & & & 1 & & & 37 & 4 & & 1 \\
\hline Prunus sp. & $\mathrm{ch}$ & charcoal & 18 & & & & & & & & 1 & & \\
\hline Quercus sp. & $\mathrm{ch}$ & charcoal & 115 & 4 & 40 & 23 & 115 & 124 & 40 & 37 & 176 & 1 & 13 \\
\hline Ulmus sp. & $\mathrm{ch}$ & charcoal & 21 & 1 & & 7 & 26 & 1 & & 4 & 1 & & 16 \\
\hline Maloideae & $\mathrm{ch}$ & charcoal & 5 & & & & 22 & & & & & & \\
\hline angiospermeae & $\mathrm{ch}$ & charcoal & 28 & & & & 5 & 2 & & 2 & 4 & 1 & 3 \\
\hline monocotyledonae & $\mathrm{ch}$ & charcoal & 23 & 4 & & & 1 & & & & & & \\
\hline \multicolumn{3}{|c|}{ total } & 230 & 9 & 40 & 30 & 170 & 127 & 40 & 80 & 186 & 2 & 33 \\
\hline
\end{tabular}

In Polgár-Piócási-dülő, white goosefoot was the most abundant species. This plant was commonly found in other settlements dated to the early stages of the Neolithic. ${ }^{46}$ In the Middle Neolithic in Slovakia, large quantities of seeds of Chenopodium type album were found in waste contexts as a result of cleaning cereals. ${ }^{47}$ Therefore, it is unclear if in the Polgár area this plant was an unwanted weed, it formed part of the ruderal vegetation or it was

46 Behre 2008; BienieK 2007; Hajnalová 2007; JACOMET 2007; KOHLER-SCHNEIDER 2007; KREUZ 2007; LITYŃSKA-ZAJĄC 2007; GYULAI 2010.
${ }^{47}$ Hajnalová 2007, 301. 

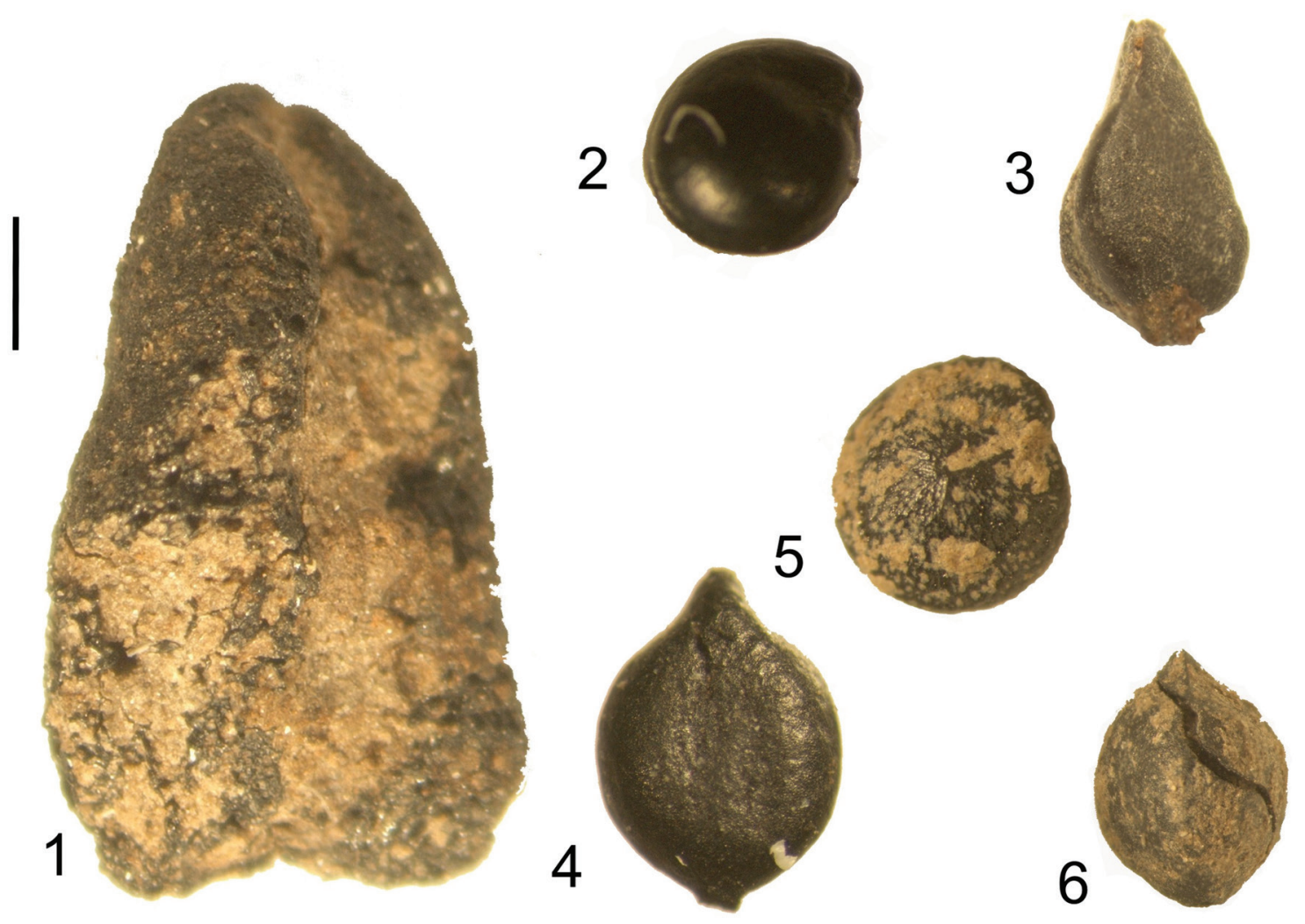

Fig. 3. Selected plant remains from Polgár-Piócási-dűlő. 1: Cerealia indet.; 2: Chenopodium t. album; 3: Polygonum aviculare; 4: Polygonum persicaria; 5: Chenopodium hybridum; 6: Rumex acetosa. Scale bar: $1 \mathrm{~mm}$. (Photos M. Lityńska-Zając and M. Moskal-del Hoyo)

consumed since ethnographic examples demonstrated that Chenopodium album could also be utilized as food. Its seeds give flour and leaves along with young shoots can be eaten without processing. ${ }^{48}$ According to Gyulai ${ }^{49}$ a high frequency of Chenopodium album in the Polgár-Ferenci-hát site, may suggest that this species could be used as "cereal replacement" during the Middle Neolithic. Nevertheless, a high frequency of Chenopodium type album is not surprising in the Neolithic plant assemblage since in the Upper Tisza floodplains different Chenopodium and Polygonum species appear in great abundance in natural mudflat communities. ${ }^{50}$ Due to this observation, these plants were excluded as indicators of the anthropogenic disturbances of natural vegetation when the human impact on landscapes during the Neolithic period in the north-eastern part of the Great Hungarian Plain was evaluated. ${ }^{51}$

In addition, even though a direct association between cultivated species and wild herbaceous plants cannot be observed in the plant assemblage from Polgár-Piócási-dülö, the ecological requirements of wild plants could indicate the diversity of their habitats, and therefore they indirectly show the environments that were exploited by people. ${ }^{52}$ This kind of analysis may show that in the proximity of the settlements, mainly rich and moderately humid soils developed, since the wild plants in general prefer rich and moderately rich soils with higher moisture content. Polygonum aviculare, Polygonum persicaria, Polygonum minus and Rumex acetosa are species that search for soil humidity. ${ }^{53}$ However, Rumex acetosa in the area of the Upper Tisza river floodplains may grow not only in wet but

\footnotetext{
${ }^{48}$ LiTYŃSKA-ZAJĄC 2005, 87.

${ }^{49}$ GyUlai 2013, 891

${ }^{50}$ MAgYari et al. 2012, Table 1.
}

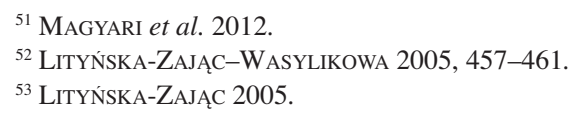


also in dry meadows. ${ }^{54}$ In the Polgár-Ferenci-hát site Polygonum aviculare, Polygonum minus and Rumex acetosa were documented. The latter is considered a plant that mainly grows on wet meadows. ${ }^{55}$

Remains of wood were found only in the form of pieces of charcoal that represent 6 taxa belonging to coniferous and broad-leaved trees. The first group was represented by Pinus sylvestris, while the latter included four taxa identified to genera (Fraxinus, Quercus, Prunus and Ulmus) and one belonging to the Maloideae subfamily. The remains of oak (Quercus sp.) are clearly predominant and this taxon was also the most ubiquitous since it appeared in all archaeological features with macroscopic plant remains (Table 2). Another frequent and quite ubiquitous taxon was elm (Ulmus sp.), which was found in eight archaeological features. Ash (Fraxinus sp.). appeared in four structures, while fruit trees representing the Rosaceae family (Prunus sp. and Maloideae) were found in the sediments of two features. Pinus sylvestris appeared only in feature 9, but it was recorded in different areas from which soil samples were gathered. In anthracology, it is usually easier to find the taxa that prevailed in local woodlands in charcoal assemblages that consist of firewood. ${ }^{56}$ In Polgár-Piócási-dülö, oak was the most abundant taxon and this may suggest that it was the most widespread tree in the area of the Neolithic settlement. On the other hand, trees of this genus were commonly employed as construction material during the Neolithic. ${ }^{57}$ Therefore, the dominance of oak in the charcoal assemblage may indicate that it was selected for timber and its remnants were later utilized as fuelwood. Nevertheless, the importance of oak trees in the area of Polgár in the Neolithic period was confirmed by the anthracological studies of other Middle and Late Neolithic settlements such as Polgár-Ferenci-hát, Polgár-Csőszhalom and Polgár 6 or other regions of the eastern part of the Great Hungarian Plain. ${ }^{58}$ In all of these settlements, other important trees identified in the charcoal samples were Ulmus sp., Fraxinus sp. and Cornus sp. The charcoal assemblage from Polgár-Ferenci-hát is of special interest since this settlement is located in close proximity to Polgár-Piócási-dülő (Fig. 1) and is also dated to the Alföld Linear Pottery culture. In this site, there were only about 350 charcoal fragments found despite the large quantity of sediments that was water-sieved. The list of the main taxa is similar to the one found at Polgár-Piócási-dülö, since Quercus sp., Ulmus sp. and Fraxinus sp. were the most frequent taxa. Besides, remains of dogwood or Cornelian cherry identified to genus level (Cornus sp.), as well as hazel (Corylus avellana), alder buckthorn (Frangula alnus), Prunus sp., Populus sp. or Salix sp. and Pinus sylvestris appeared. ${ }^{59}$

The predominance of Quercus accompanied by frequent Ulmus and Fraxinus in all charcoal assemblages from Polgár-Piócási-dülő suggests that mixed deciduous forests could develop in the vicinity of this settlement. Unfortunately, based on the anatomical characteristic of these trees it is impossible to identify the species. In the case of oak, all of the charcoal fragments belonged to deciduous oak of the subgenus Quercus. ${ }^{60}$ In the Great Hungarian Plain, this genus could be represented by three species: $Q$. robur, $Q$. petraea and $Q$. pubescens. However, nowadays in the area of the Tisza river, $Q$. robur prevails. ${ }^{61}$ Elm and ash could also be identified to genus level, currently Ulmus minor, U. laevis, Fraxinus excelsior and F. angustifolia ssp. pannonica are among the most typical species of the region. ${ }^{62}$ The aforementioned elm and ash trees are usually found on moist, rich and deep soils, in which they form part of different riparian forests. ${ }^{63}$ The natural conditions of these sites, located on the highest parts of the region and in proximity to the Tisza river, could indicate that the closest areas were probably covered by higher floodplain forests and steppe oak woods. In this region, both forest formations belong to the natural vegetation and they are composed of different species of oak, elm and ash trees. In the floodplain areas, mainly oak woodlands with $Q$. robur, $U$. laevis and $U$. minor occur, ${ }^{64}$ while in loess-mantled surfaces, different oak species such as $Q$. robur, $Q$. petraea, $Q$. pubescens, and $Q$. cerris are commonly accompanied by $U$. minor ${ }^{65}$ Interestingly, the analysis of the relative abundance of arboreal taxa present in different palynological records from the Great Hungarian Plain has demonstrated that in the middle Holocene wooded steppe developed. ${ }^{66}$ The existence of naturally semi-open parts in the landscape with mixed-oak forest steppes was also previously suggested for the Atlantic pe-

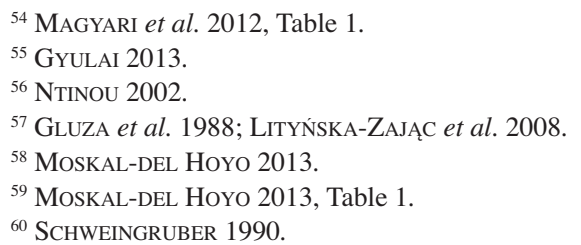

${ }^{61}$ BoHN-NeUHÄUSL 2004; DoniţA-KaRAMYŠEVA 2004; BÖLÖNI et al. 2008; MoLNÁR et al. 2012.

${ }^{62}$ BoHN-NeuHäusL 2004.

${ }^{63}$ Soó 1966; Bohn-Neuhäusl 2004; Seneta-DolaTOWSKI 2004; BÖLÖNI et al. 2008.

${ }^{64}$ BARTHA et al. 1995.

${ }^{65}$ MolnÁr et al. 2012.

${ }^{66}$ MAGYARI et al. 2010. 
riod, and was also observed in other pollen deposits from the lowlands, including Csaroda-Nyíres-tó, ${ }^{67}$ Ecsegfalva 23/Kiri-tó, ${ }^{68}$ Bátorliget, ${ }^{69}$ and from the mountainous regions, including Sirok-Nyírjes-tó ${ }^{70}$ Kis-Mohos-tó, ${ }^{71}$ and Nagymohos. ${ }^{72}$ Overall, the anthracological data are in accordance with the natural potential vegetation and are corroborated by palynological studies.

In summary, it can be stated that the natural environment offered habitats in which oak trees dominated in the local vegetation, forming floodplain forests and wooded steppes. These surroundings offered sufficient wood that could be utilized for different purposes. They also provided food in the form of fruits (Quercus, Prunus and Maloideae) and formed an optimal habitat for domestic animals. Arable fields were probably also established in the vicinity of the settlements, since the area was abundant in fertile soils. This may be suggested by the findings of macroscopic plant remains that represented cultivated species, but it can also be inferred from the analysis of wild herbaceous plant remains. Moreover, this plant material may indicate the exploitation of more humid habitats probably developed near the ancient river-bed.

\section{GENERAL TRAITS OF THE EASTERN LINEAR POTTERY CULTURE SETTLEMENT AT POLGÁR-PIÓCÁSI-DŰLŐ}

The features of the ALBK settlement date from two periods. The cluster of multi-functional pits yielding a rich assortment of finds, the handful of post-holes and an unusual ritual well found in the southern part of the investigated area formed one unit from the earliest phase of the Middle Neolithic (ALBK I) (Fig. 4). We took samples for radiocarbon measurements from two pits beside the eastern trench wall (Feature 132: 5475 (68.2\%) 5375 cal BC; Feature 182: $5370(68.2 \%) 5230 \mathrm{cal} \mathrm{BC})^{73}$ (Figs 5-6). One interesting trait of these two pits was that they also contained finds from the settlement's late occupation phase. ${ }^{74}$ These pits fell into the boundary zone between the two occupations, and there is nothing surprising about the fact that the settlement's later occupants dug their pits into the earlier, infilled features of the site's earlier inhabitants. The superimposed settlement features reflect a discontinuity in the settlement's occupation. However, given that the area occupied during the early period is spatially discrete from the late occupation and that archaeological imprints of contact can only be noted in the boundary zone between the two occupations, we can hardly claim that a link of memory had not been forged between the communities of the two periods.

The settlement's other occupation can be assigned to the late phase of the Middle Neolithic (ALBK IV) (Figs 7, 11, 12). In view of its distinctive ceramic decorative style, this period can be securely determined even from the existing relative chronological framework. ${ }^{75}$ The settlement's most densely occupied area was the central part during the late period. Three houseplans representing the remains of timber-framed buildings outlined a distinct area with three multi-functional pits. Immediately to their north, we found the remains of two other timber-framed buildings and several smaller pits.

Associated with the above features were a few burials, which expressed the community's ritual beliefs. ${ }^{76}$ Some members of the community played a role in the settlement's life even after their death. The key to the selection of the individuals and their symbolic presence lies in the period's ritual memory. ${ }^{77}$ The eight graves contained the burials of five adults, two children and an infant, all dating from the late period. The adults were laid on their left side

\footnotetext{
${ }^{67}$ Harrington, 1995, SÜMEgi, 1999, cited in: JuHÁsZ 2005; MAGYARI et al. 2008.

${ }^{68}$ WILLIS 2007.

${ }^{69}$ WILLIS et al. 1995.

${ }^{70}$ GARDNER 2002; GARDNER 2005.

${ }^{71}$ WILLIS et al. 1998

${ }^{72}$ MAgYari et al. 2001; MAGYARI et al. 2012

${ }^{73}$ The measurements were obtained with the Obresoc project and with the help of Laboratoire de Mesure du Carbone 14, Saclay (Artemis), France.

${ }^{74}$ The two pits were situated under the wall of the trench opened according to the investor's specifications, and thus the superposition of the pits dated to the two periods could only be noted along a small section of the trench wall's profile. This was one of the reasons
}

why samples from these pits were submitted for radiocarbon analysis. The results confirmed that the uncovered pit sections had been filled in during the early (ALBK I) phase, while the one dug into it was considerably later (ALBK IV). The greater part of the latter pit was situated outside the investigated area and could not be excavated.

${ }^{75}$ In the Alföld (Great Hungarian Plain), the late phase of the Middle Neolithic (ALBK IV) can be most easily distinguished on the basis of the distinctive ceramic styles of the different regional groups (Esztár and Tiszadob groups, Bükk and Szakálhát Cultures) (KALICZ-MAKKAY 1977).

${ }^{76}$ The beliefs of prehistoric communities are perhaps best reflected in burial customs (ZALAI-GAÁL 1988).

${ }^{77}$ ASSMANN 1992. 


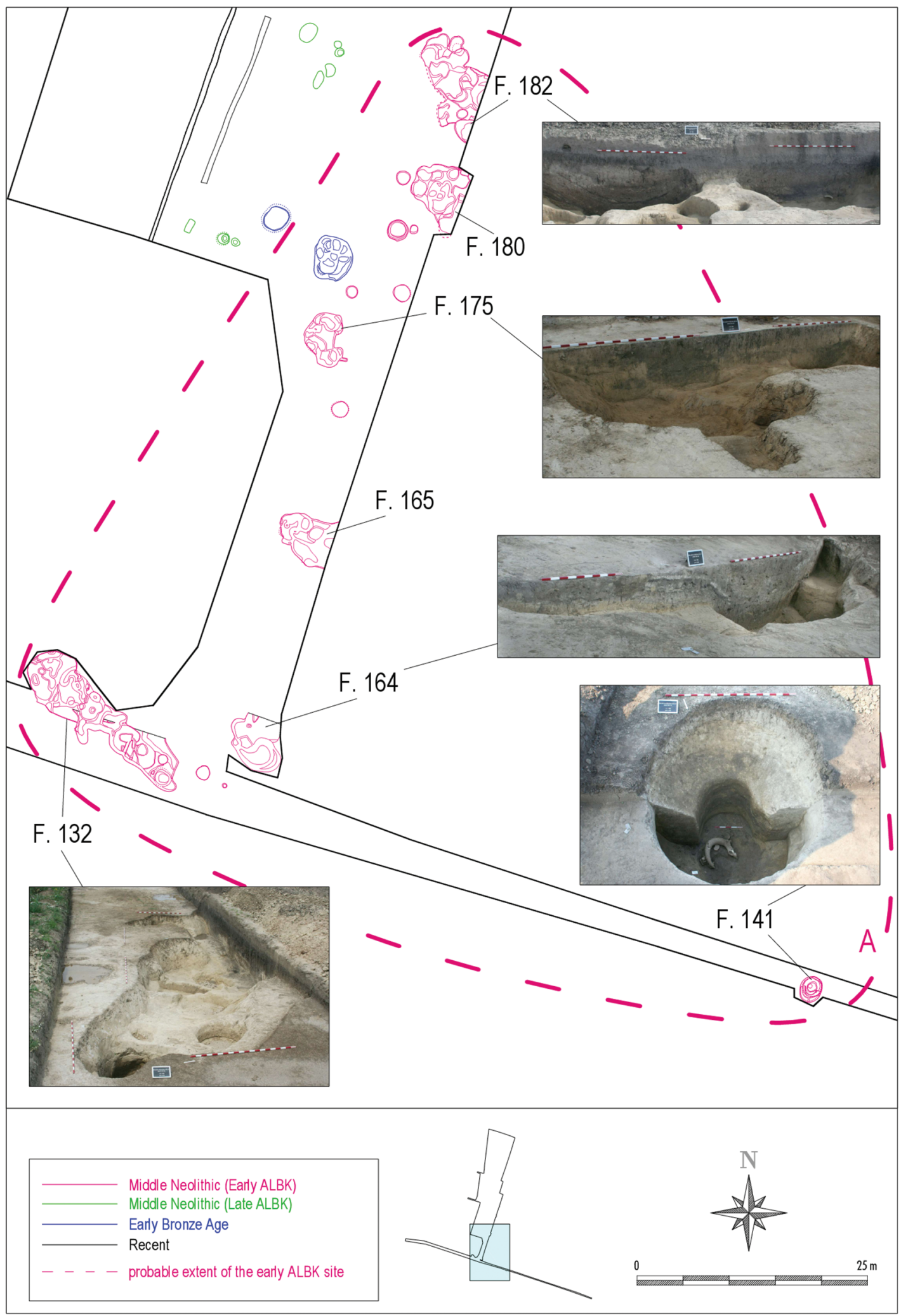

Fig. 4. Polgár-Piócási-dülő. Selected archaeological features of the early ALBK occupation 


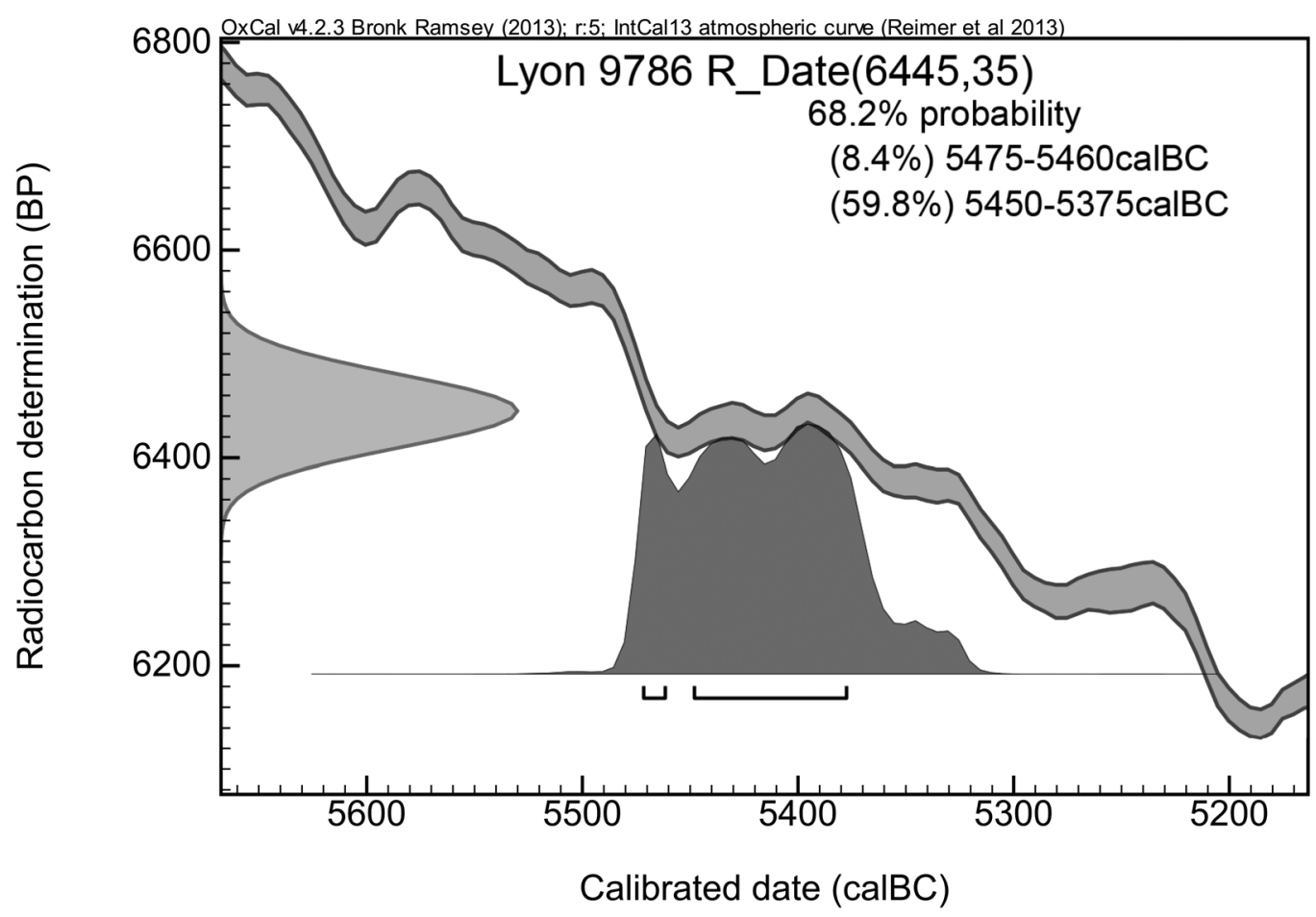

Fig. 5. Polgár-Piócási-dűlő. The absolute time intervals

of the ALBK I estimated from one calibrated radiocarbon date taken from Feature 132

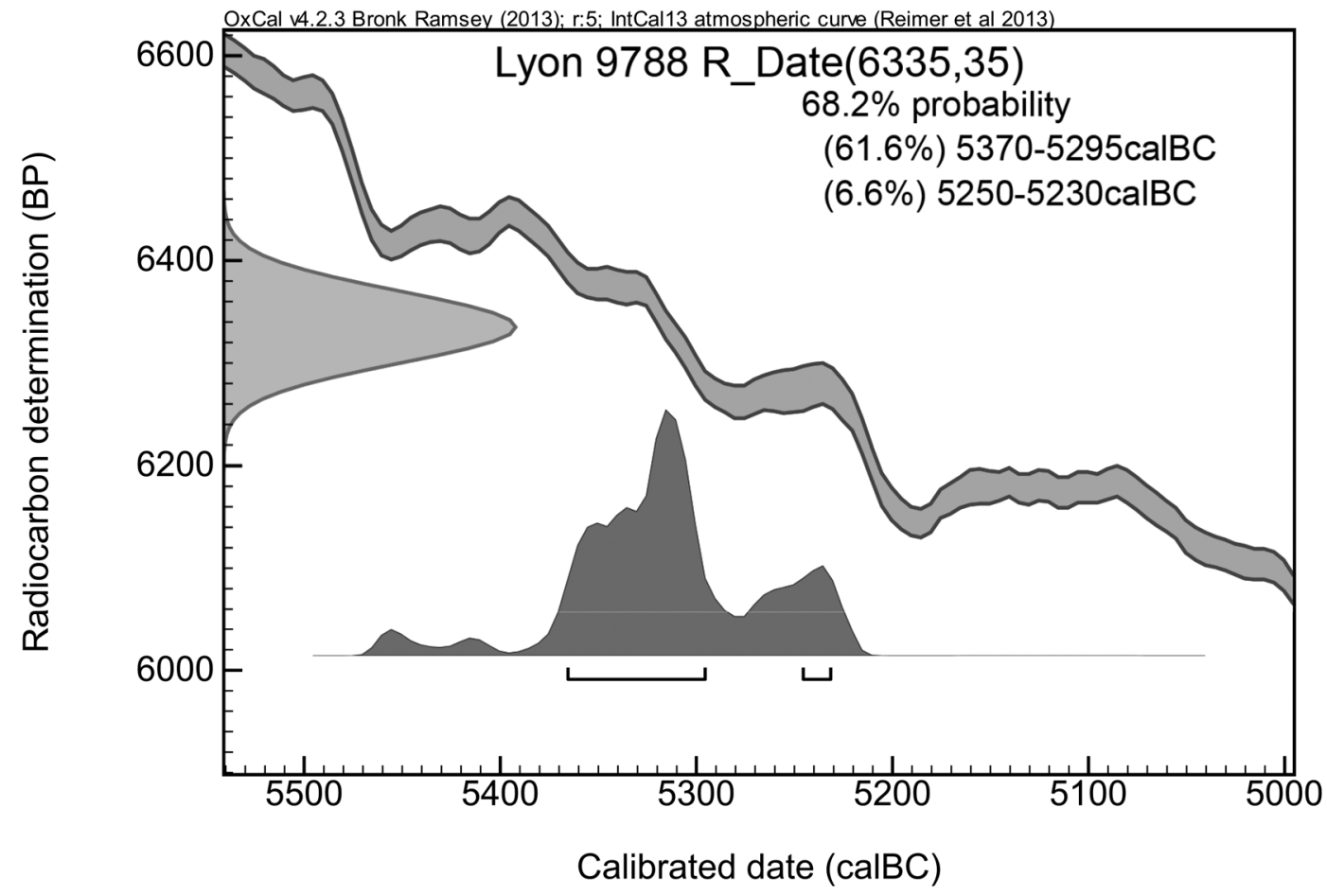

Fig. 6. Polgár-Piócási-dűlő. The absolute time intervals

of the ALBK I estimated from one calibrated radiocarbon date taken from Feature 182 


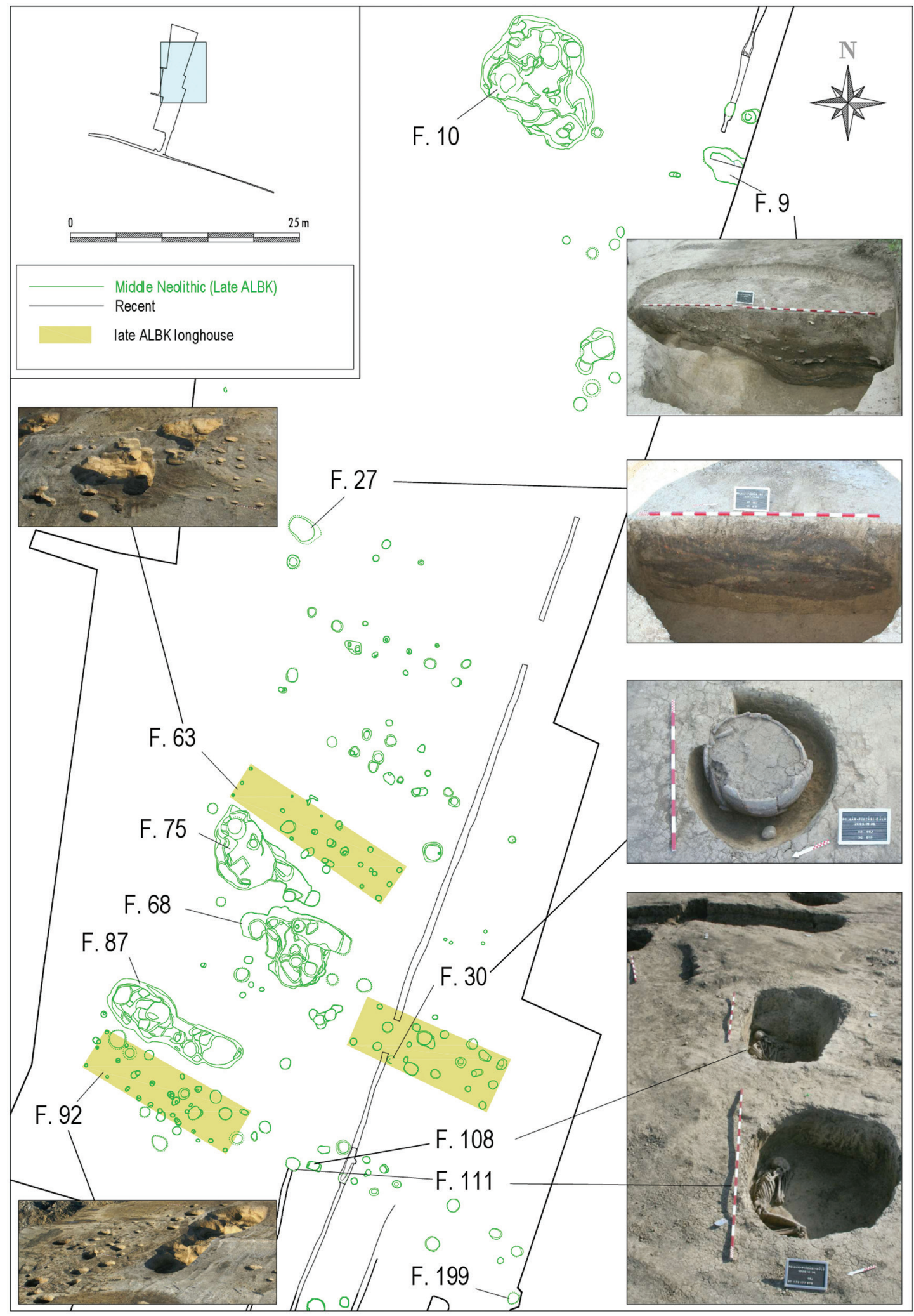

Fig. 7. Polgár-Piócási-dűlő. Selected archaeological features of the late ALBK occupation 


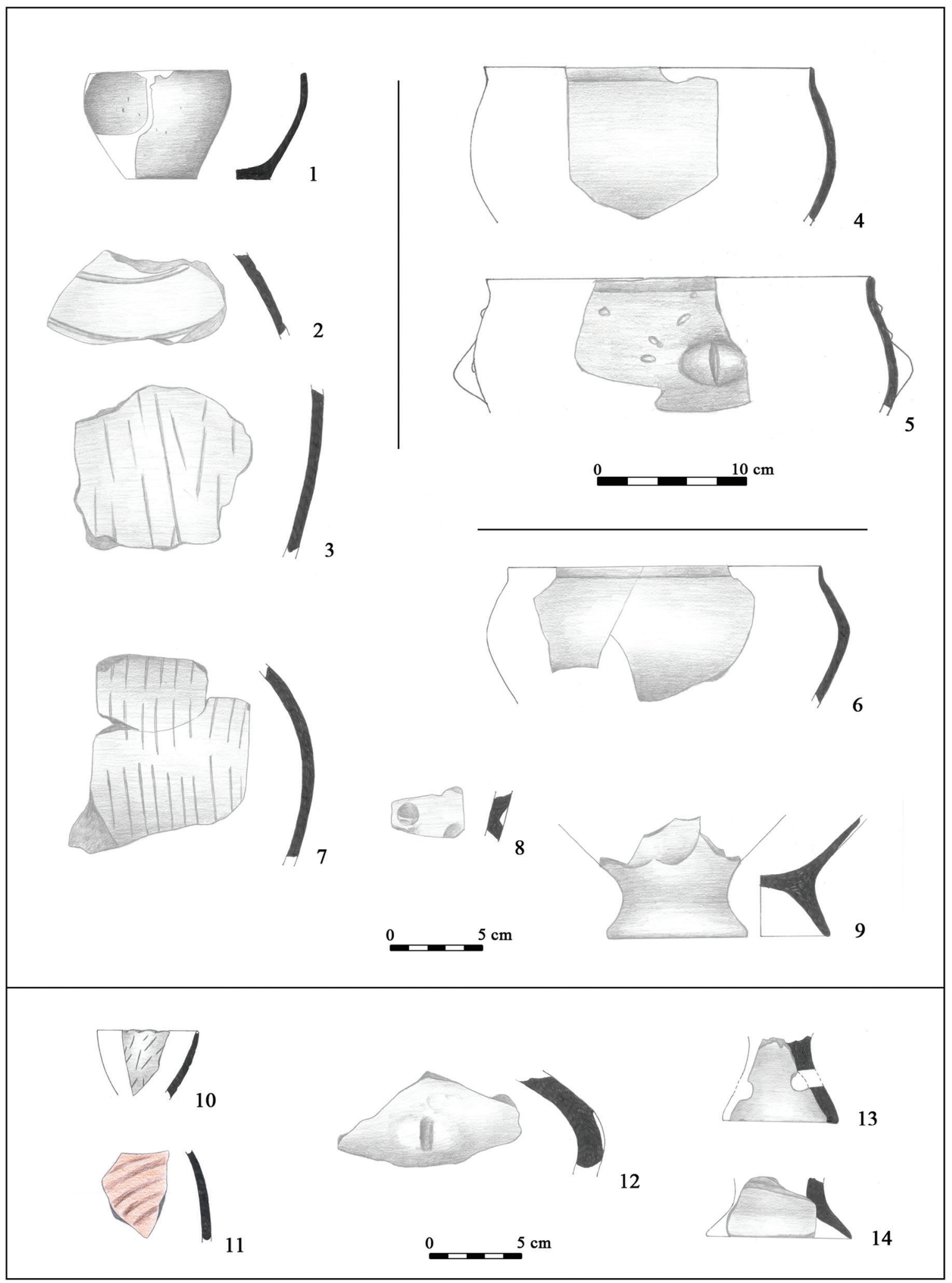

Fig. 8. Polgár-Piócási-dülő. Selection of the characteristic vessel types of the early ALBK occupation. 1-9: Feature 132; 10-14: Feature 141 


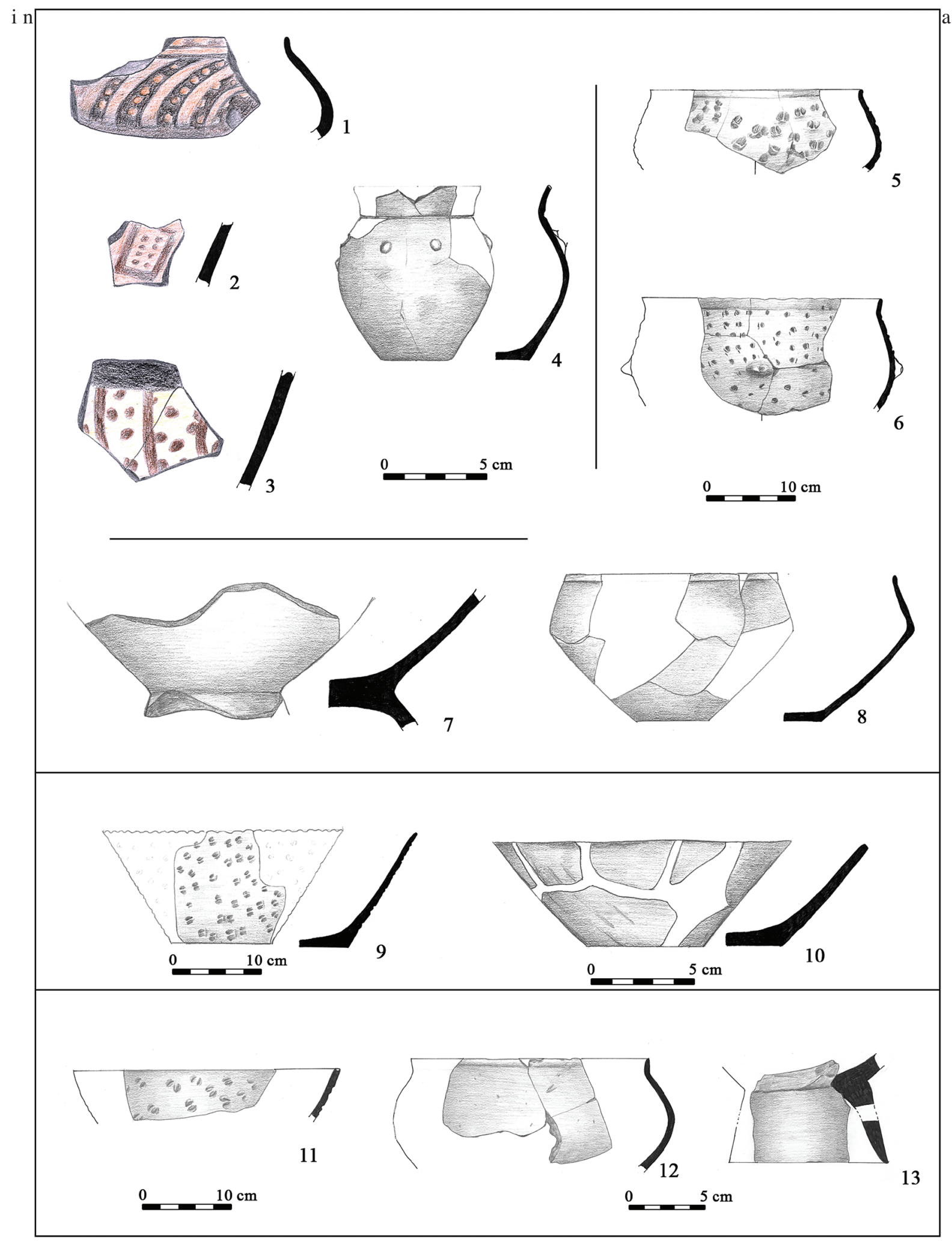

Fig. 9. Polgár-Piócási-dűlő. Selection of the characteristic vessel types of the early ALBK occupation. 1-8: Feature 164; 9-10: Feature 165; 11-13: Feature 175 


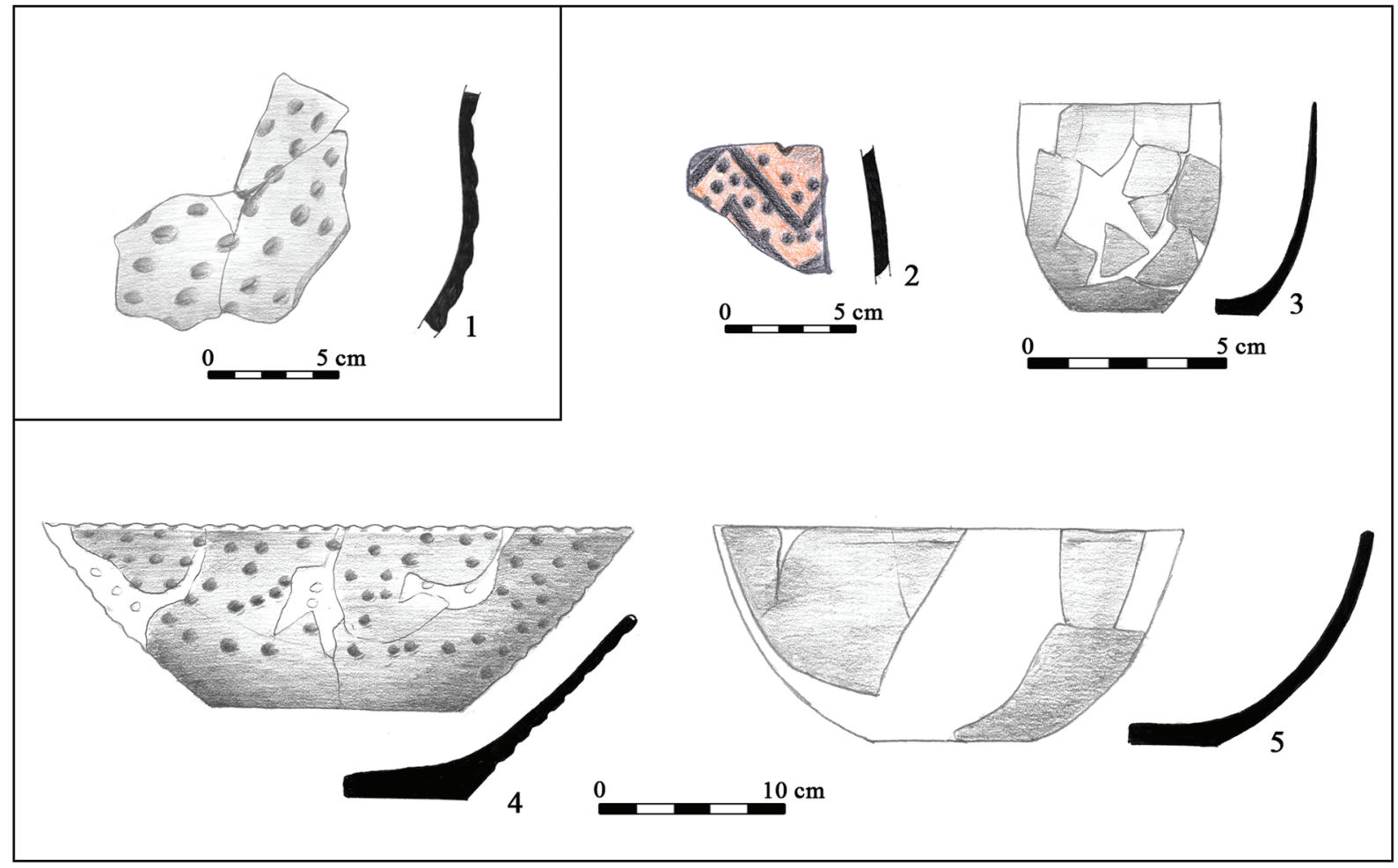

Fig. 10. Polgár-Piócási-dủlő. Selection of characteristic vessel types of the early ALBK occupation. 1: Feature 180; 2-5: Feature 182

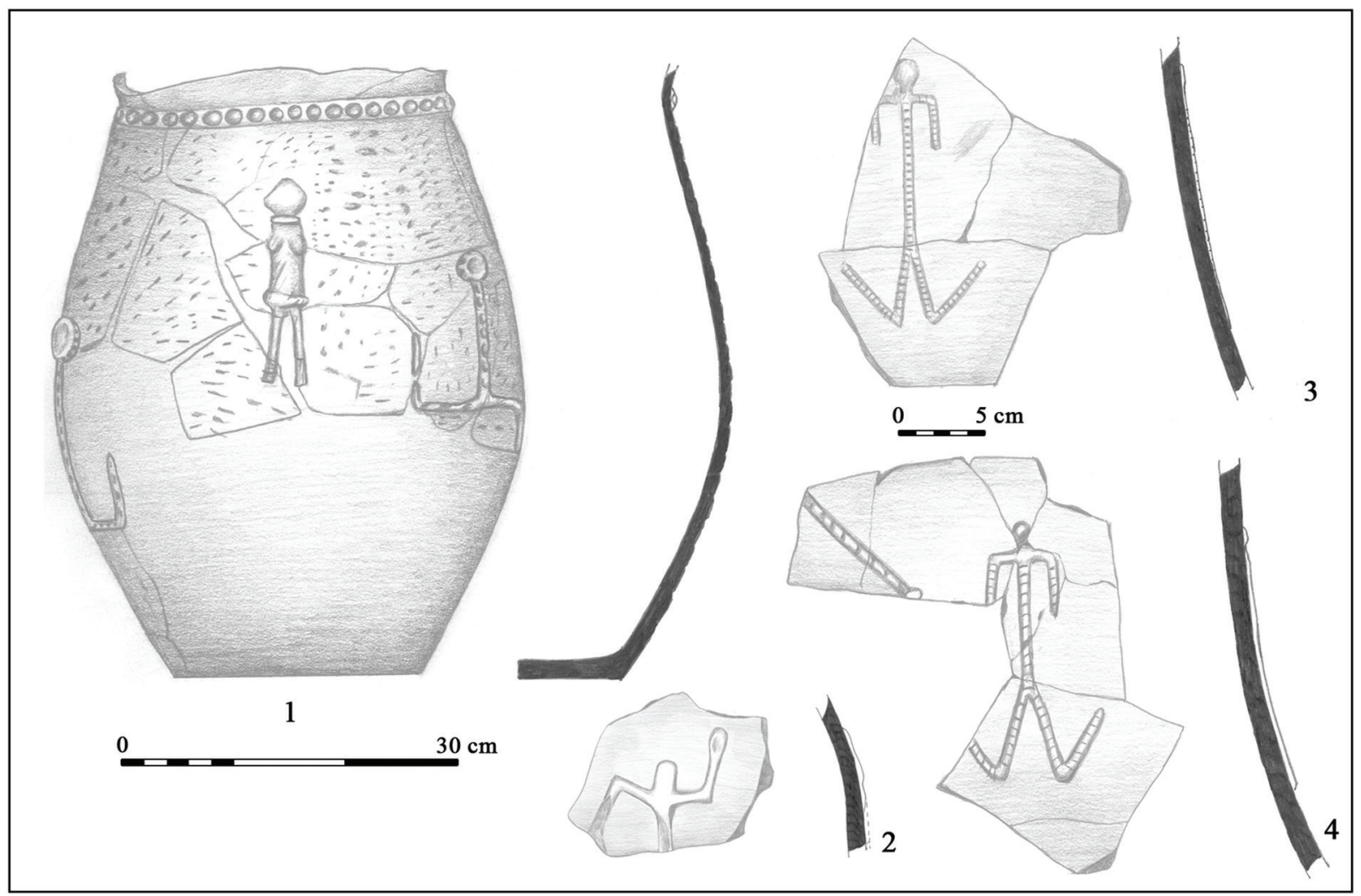

Fig. 11. Polgár-Piócási-dủlő. Storage jars with anthropomorphic decoration. 1: Feature 27; 2: Feature 87; 3-4: Feature 180 Acta Archaeologica Academiae Scientiarum Hungaricae 65, 2014 


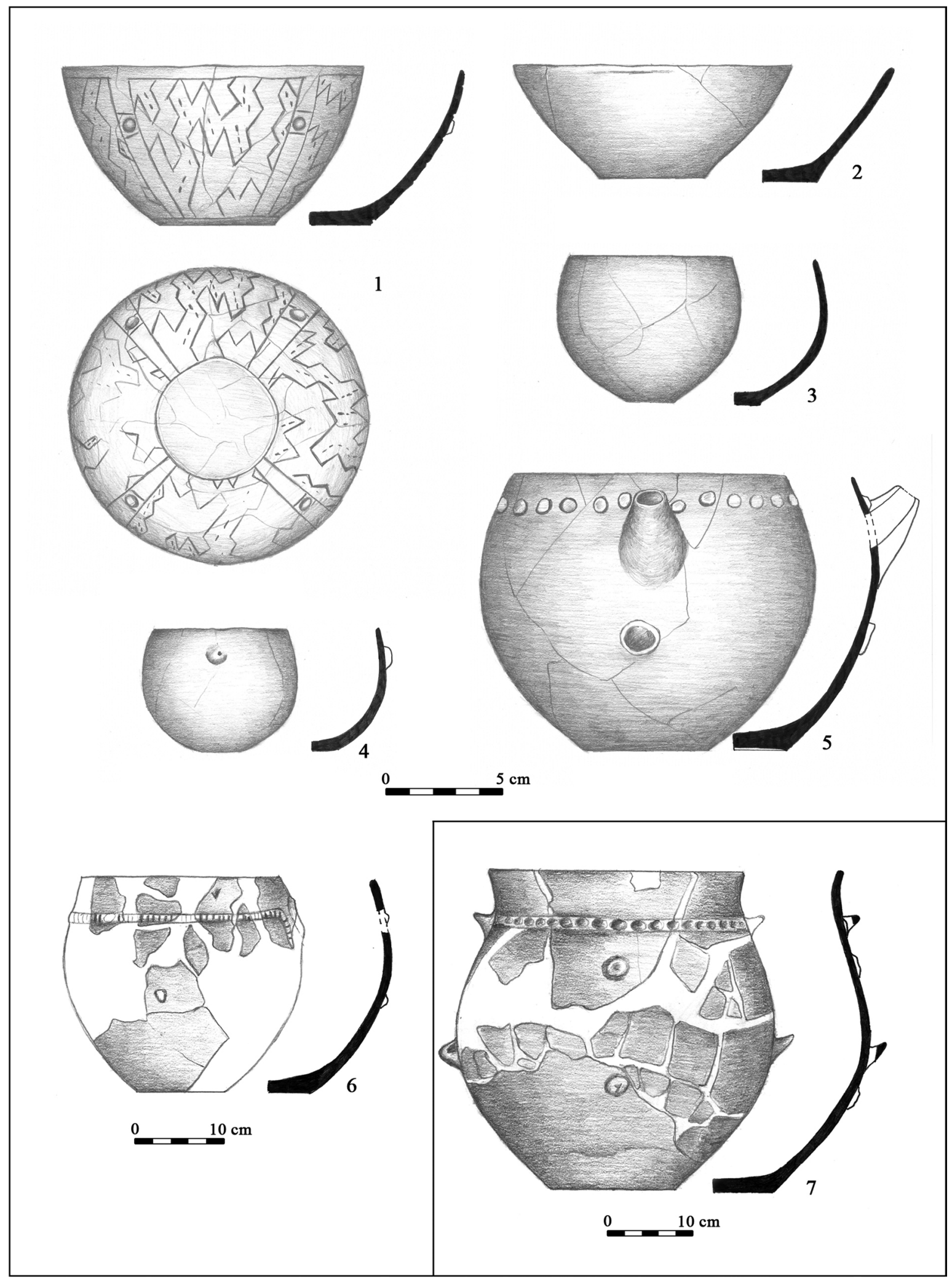

Fig. 12. Polgár-Piócási-dülö. Selection of the characteristic vessel types of the late ALBK occupation. 1-6: Feature 9; 7: Feature 10 
strongly crouched position; one burial contained a small vessel (Feature 32), and the remains of red ochre were identified in two other burials (Features 17 and 108). Four of the adult burials had been deposited in regular grave pits, while the fifth was found on the floor of a round pit. Since the formalised placement of the body could be noted in this case too, it can be regarded as a regular burial despite its unusual location.

The system of timber-framed houses with multiple rooms (Features 63 and 92) and the associated longpits (Features 68, 75 and 87) (Figs 13.1, 2, 8, 9) conforms to the general architectural traits and the settlement layouts of the ALBK period. ${ }^{78}$ The $18-20 \mathrm{~m}$ long and 5-6 m wide houses with a pitched roof were the settings of various domestic and economic activities whose diversity is attested through the rich assortment of finds recovered from the fill of the associated pits.

The so-called multi-functional pits preserve the imprints of two main activity types. They were principally used for extracting the clay necessary for pottery production and house plastering. Later, they were infilled with refuse. The slow, stratified infilling suggests the community's formalised activity (structured deposition). ${ }^{79}$ The pottery sherds placed on the burnt daub fragments were returned to whence they originated. Some of the vessels appear to have been intentionally broken, at least judging from the pieces representing fragments of the same vessel in the case of a few storage jars. Similarly, we may assume the deliberate burning of the house in some cases. ${ }^{80}$ One of the period's oft-encountered phenomenons is a potent belief in the power of fire as a medium of transformation. The firing of clay vessels, the fire burning in the domestic hearth, the deliberate destruction by fire of houses that were no longer fit for habitation and the cremation of certain deceased are reflections of the occupants' belief in the awe-inspiring power of fire. ${ }^{81}$ These phenomena formed an integral whole in the ritual practices and beliefs permeating daily activities. Thus, the process of the infilling of the large longpits on ALBK settlements should not be conceptualised as the casual discardment of refuse, but rather as a form of deliberate storage activity interfused with ritual elements.

The rich assortment of finds recovered from the fill of these enormous settlement pits is one of the primary sources of household archaeology studies. ${ }^{82}$ Patterns in household activities can be fairly well reconstructed from the comparative analysis of reliable statistics on the pottery fragments as well as on lithic and bone implements and animal bones. For example, cereal storage and grinding, various kitchen and craft activities can be accurately quantified, and as economic and social units, they can be satisfactorily identified for the purposes of modern analytical studies. ${ }^{83}$

Some interesting peripheral features could be noted to the north and north-east of the above-described central part of the ALBK settlement. ${ }^{84}$ The few larger pits found scattered over increasingly larger areas devoid of any other features preserve the imprints of certain unusual activities. One of the pits (Feature 9) in the northern part of the excavation trench contained a fairly thick layer of riverine mussels (Fig. 12.2-6). The shafts for obtaining water on the floor of the pits and other features suggest that intensive work activities such as leather working, tool production, drying, storage and the like were performed in the sparsely occupied areas bordering on the central habitation area, even though no buildings with a more massive roof structure were discovered in this area. East of the above pit, we found another pit with a remarkable fill (Feature 8). Lying among the burnt daub fragments and other refuse was an assemblage made up of an intact and a broken quern stone, a broken pounder, and intact and unworked animal bones. The presence of the deposit made up predominantly of cattle bones, the apparent raw material of the implements to be manufactured, among the refuse of the settlement indicates the sudden closure and abandonment of a bone tool manufacturing workshop.

Another pit with a rich fill mixed with traces of burning (Feature 10) (Fig. 12.7) uncovered in this peripheral area yielded two intact vessels, which again seems to confirm our assumption that the area was used for various craft activities that were concluded and discontinued for some reason. We did not find any indication of this rapid

\footnotetext{
${ }^{78}$ The basic units of the LBK Culture can be quite accurately determined. There is ample literature on this subject, see, e.g., LÜNING 1991; DOMBORÓCZKI 1997.

${ }^{79}$ Chapman 2012; Kalla 2013.

${ }^{80}$ ChapMan 1999; Kalla 2013.

${ }^{81}$ SZEVERÉNYI 2013.

${ }^{82}$ Household archaeology has gained prominence in prehistoric studies during the past years and a conference focusing on this
}

theme was held in Százhalombatta in 2011. The papers read at this conference appeared as Volume VII of $\operatorname{M} \Omega M O \Sigma$, published in Ősrégészeti Levelek / Prehistoric Newsletter 13 (2011) [2013].

${ }^{83}$ These are currently in progress (e.g. the classification of the daub fragments and the pottery).

${ }^{84}$ These pits are good examples of the pre-conceived use of space (LÜNING 1991; KALLA 2013). 


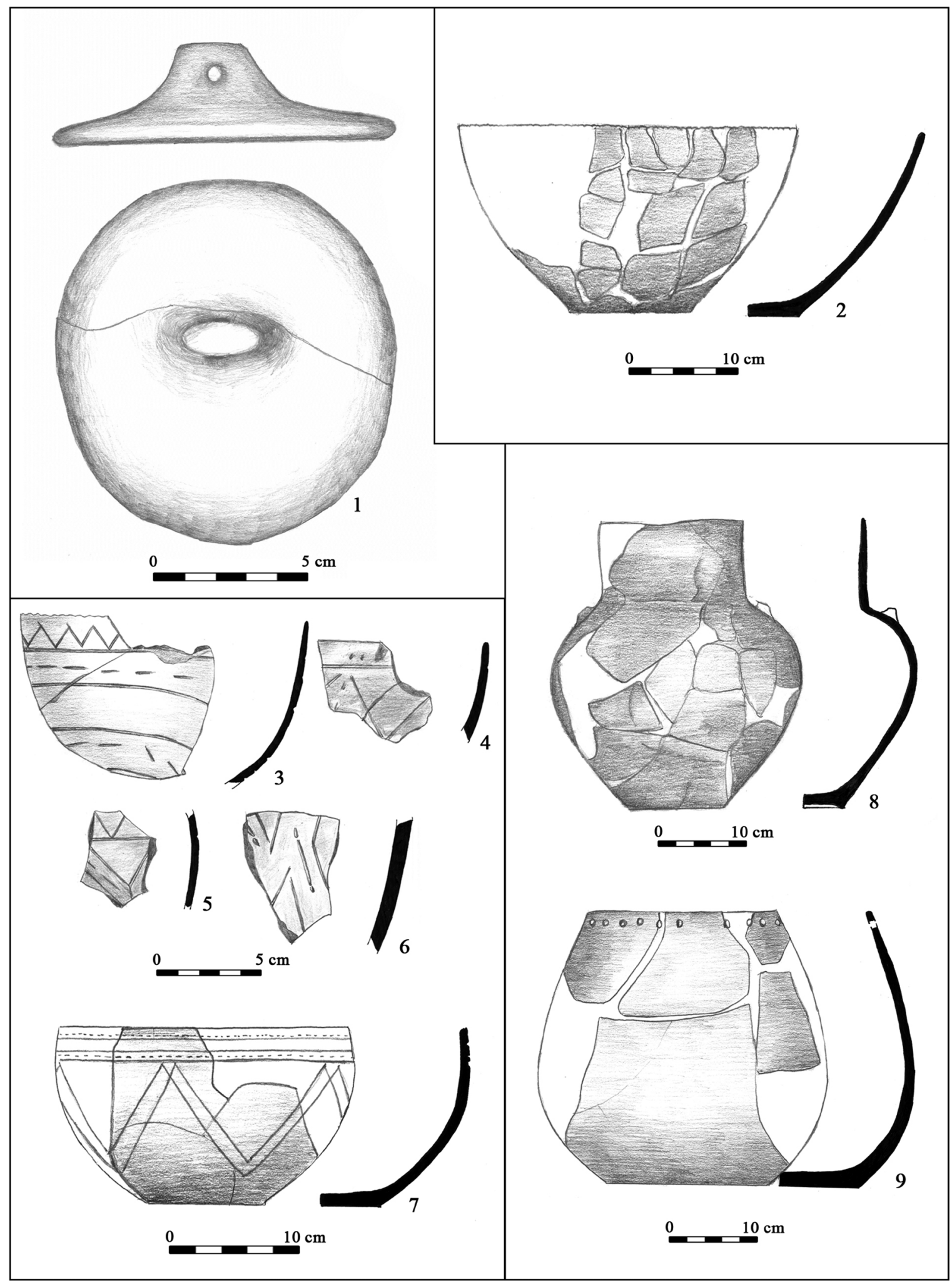

Fig. 13. Polgár-Piócási-dülö. Selection of the characteristic vessel types of the late ALBK occupation. 1: Feature 68; 2: Feature 75; 3-7: Feature 199; 8-9: Feature 87 
conclusion in the settlement's central area, suggesting that it can be attributed to some internal structural reorganisation rather than to an external threat.

The longpits with a fill rich in finds (Figs 8-10) can also be found in the early period, even though we did not find any traces of timber-framed buildings. However, the volume of the burnt daub fragments in some of the pits exceeded by far the amount of similar daub fragments recovered from the longpits flanking the houses of the late period. The rich inventory of chipped stone implements recovered from the pits of the early period was very striking. It seems to us that the range of domestic activities around the houses was no less intensive during this period. There is only indirect evidence for the presence of post-framed buildings during this period because we did not find any direct traces of such structures in the investigated area. However, the rich fill of the densely space longpits and the large amount of burnt daub with twig imprints indicate the one-time existence of houses with wattle-and-daub walls built around a framework of upright timbers during this period. The broken vessels, including several jars used for storing cereals, too would suggest the existence of roofed buildings. ${ }^{85}$ In sum, we may say that the use of space during the early period was as complex and as varied as during the settlement's late period. The site's occupants had a multi-facetted economic, social and spiritual life in both occupation periods.

\section{THE UNUSUAL FEATURES OF THE EASTERN LINEAR POTTERY CULTURE SETTLEMENT}

We found several unusual archaeological features from both the early and the late occupation that were rare and uncommon in the life of the ALBK settlement.

One of the most remarkable features of the entire site was Feature 141, a ritual well (Figs 4 and 8.10-14). ${ }^{86}$ The cylindrical well lay in the south-eastern part of the intensively occupied area during the settlement's early period; it was filled with clay after its use. Some time after the infilling of the well, a smaller, likewise cylindrical shaft was dug down to the level of the water table. This was also filled up with clay preserving the material remnants of some ritual activity (perhaps a sacrificial ceremony). The two phases of infilling could be clearly distinguished: the first infilling was slower, with a lengthier duration, indicated by the compact fill containing little settlement refuse, while the second was a more looser fill without any indication of a long duration of infilling. The later shaft was probably backfilled artificially, perhaps during a day, with the material remnants of the ritual activity that was perhaps associated with the water concealed deep in the ground. Burnt animal bones and pottery fragments mixed with black ash lay on the floor once covered with water of the new well shaft. Above them was a layer of earth mixed with burnt debris among which lay pottery fragments and animal bones, and an aurochs horn core. The first infilling cannot have lasted for long either because the homogeneity of the layer at the bottom of the well and the small number of finds would suggest that the danger posed by an open well on the settlement called for its rapid backfilling. This procedure can be conceptualised as series of everyday rites. ${ }^{87}$ The second shaft can clearly be interpreted as part of a sacral ritual performed to ensure access to the floor of the one-time well as part of a sacrificial ceremony (the animal bones and the aurochs horn core would suggest an animal sacrifice). It would appear that this technically rather risky venture (the walls of the narrow shaft in the previous infilled earth could collapse at any moment) was an indispensable part of the sacral ritual.

The three broken storage jars bearing a figural decoration on their exterior (a structured deposit) (Fig. 11) from the settlement's late occupation period are of particular importance. ${ }^{88}$ Several large storage jars were recovered from the longpits flanking the timber-framed houses. In general, we found a strikingly high number of intact and broken quern stones, which together with the many storage jars for cereals (over eight such vessels) were a reflection of a process involving intensive cereal cultivation - storage - bread making. The perhaps most characteristic relic of this process was found in Feature 30 (Fig. 7) containing a large, intact storage jar dug into the floor of the house and a pounder placed beside it. The fragments of the other storage jars were deposited together, in the fill of refuse pits, indicating that the storage jars that were no longer used had been deliberately broken, imbued with new qualities and placed in the pits (rite of passage). ${ }^{89}$ Three fragments bore depictions of stick figures in relief (Fig. 11).

\footnotetext{
${ }^{85}$ ChAPMAN 2012.

${ }^{86}$ The well was analysed and interpreted as a ritual pit by Zsigmond Hajdú in his doctoral dissertation (HAJDÚ 2007).

${ }^{87}$ Some scholars draw a sharp distinction between sacral and everyday forms in their analysis of ritual processes (TURNER 2002).

${ }^{88}$ CHAPMAN 2012.

${ }^{89}$ VAN GENNEP 2007.
} 
One fragment was decorated with a scene of five human figures: four stick figures dancing around a realistically portrayed female figure. This symmetric composition undoubtedly refers to a symbolic activity (perhaps a fertility dance) expressing the period's ritual thought (Fig. 11).

Several other archaeological phenomena could be cited which have well-distinguishable, individual traits. These include the broken storage jars, and the intact vessels and human skull fragments found in the large refuse pits.

The overwhelming majority of the settlement features and the various phenomena observed on the Piócásidülö settlement are consistent with the general traits of the cultural elements that are peculiar to the ALBK.

\section{LITHIC ASSEMBLAGES}

The site of Polgár-Piócási-dűlő yielded 272 chipped stone artefacts which were found in the features representing the Eastern Linear Pottery Culture (ALBK). The majority of artefacts (207 specimens) occurred in the pits dated to the early phase (Szatmár II or ALBK I), namely in features 132, 141, 165, 180, and 182. Features from the late phase of ALBK yielded only 65 artefacts.

\subsection{Raw materials}

The most important raw material in all the major tool categories in the early phase is obsidian, which accounts for $94.6 \%$ of all artefacts. Limnoquartzites are next in importance $-3.8 \%$; quartzites and radiolarites are represented by single specimens (Table 3). Transcarpathian raw materials were absent.

\subsection{The structure of major technological groups}

In the early phase the dominant group is flakes (38.6\%). The second group constitutes of blades with relatively high index (28.0\%), and tools (16.9\%) made exclusively of obsidian. For other groups see Table 3. This quantitative structure indicates a limited on-site production; blanks were partly produced off-site.

\subsubsection{Cores}

The features of the early phase contained 14 cores (and two fragments) while the later features yielded only 5 cores. Most cores from the early phase are obsidian specimens (14 specimens), and only two are from limnoquartzite. In features dated to the later phase the proportion of limnoquartzite is relatively higher ( 3 specimens) than that of obsidian ( 2 specimens). All the specimens represent an advanced stage of reduction, whereas initial cores do not occur. The presence of a fairly large, unworked obsidian concretion $(80 \times 48 \times 18 \mathrm{~mm})$ in one of the early fea-

Table 3. Polgár-Piócási-dűlő. Early phase: raw material in the major technological groups

\begin{tabular}{|l|c|c|c|c|c|c|c|c|c|}
\hline \multicolumn{1}{|c|}{ Raw material } & Core & Flake & Blade & Chips & $\begin{array}{c}\text { Splintered } \\
\text { pieces }\end{array}$ & Tool & Splinter & N & \% \\
\hline Obsidian & $14+1^{*}$ & 75 & 54 & 11 & 3 & 35 & 3 & 196 & 94,6 \\
\hline Limnoquarzites & 2 & 4 & 2 & & & & & 8 & 3,8 \\
\hline Burnt & & 1 & & & & & & 1 & 0,4 \\
\hline Radiolarite & & & 1 & & & & & 1 & 0,4 \\
\hline Quartzite & & & 1 & & & & & 1 & 0,4 \\
\hline Total & $16+1$ & 80 & 58 & 11 & 3 & 35 & 3 & 207 & \\
\hline$\%$ & 8,2 & 38,6 & 28,0 & 5,3 & 1,4 & 16,9 & 1,4 & & \\
\hline
\end{tabular}

*nodule 

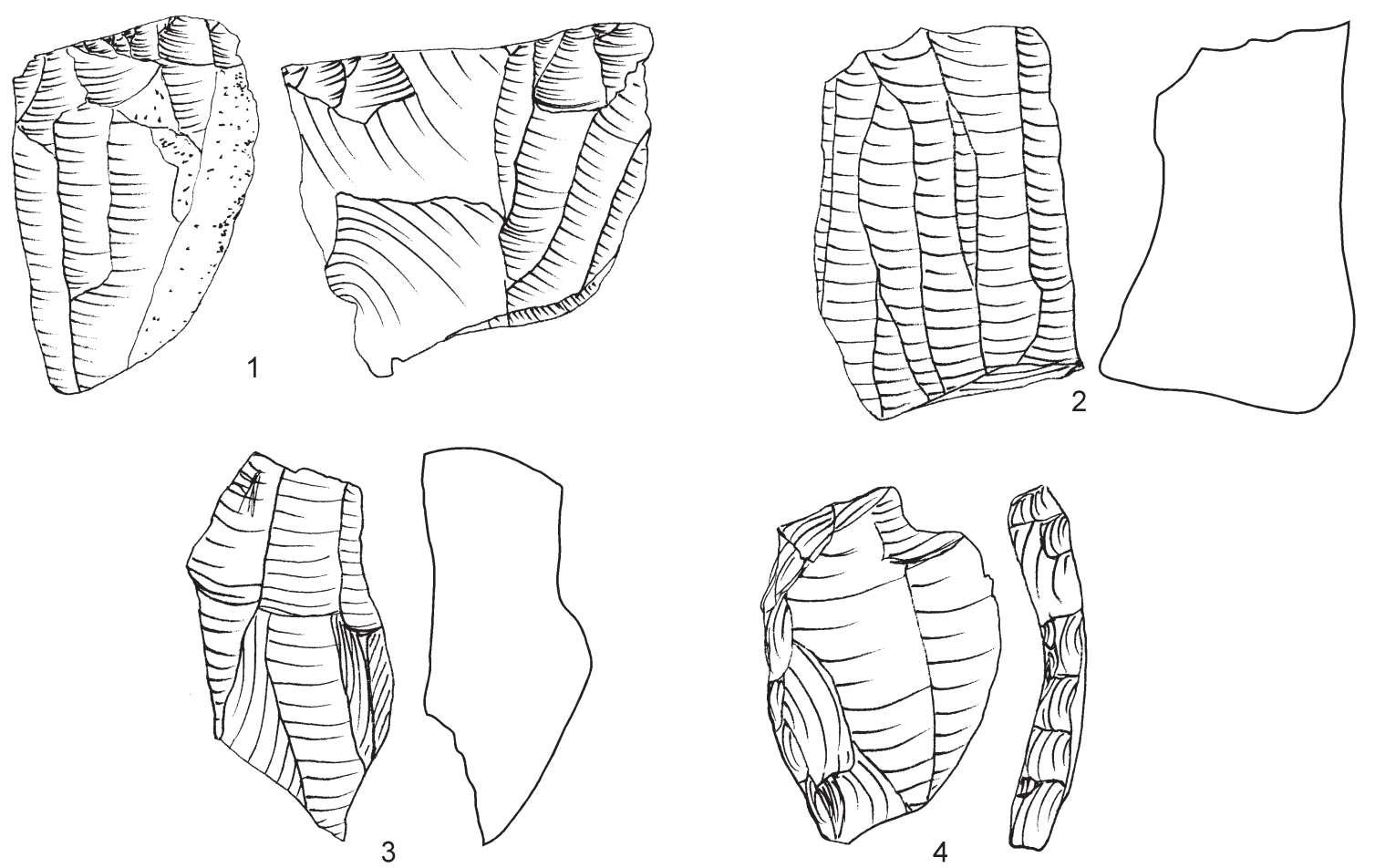

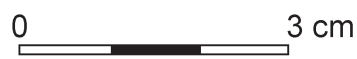
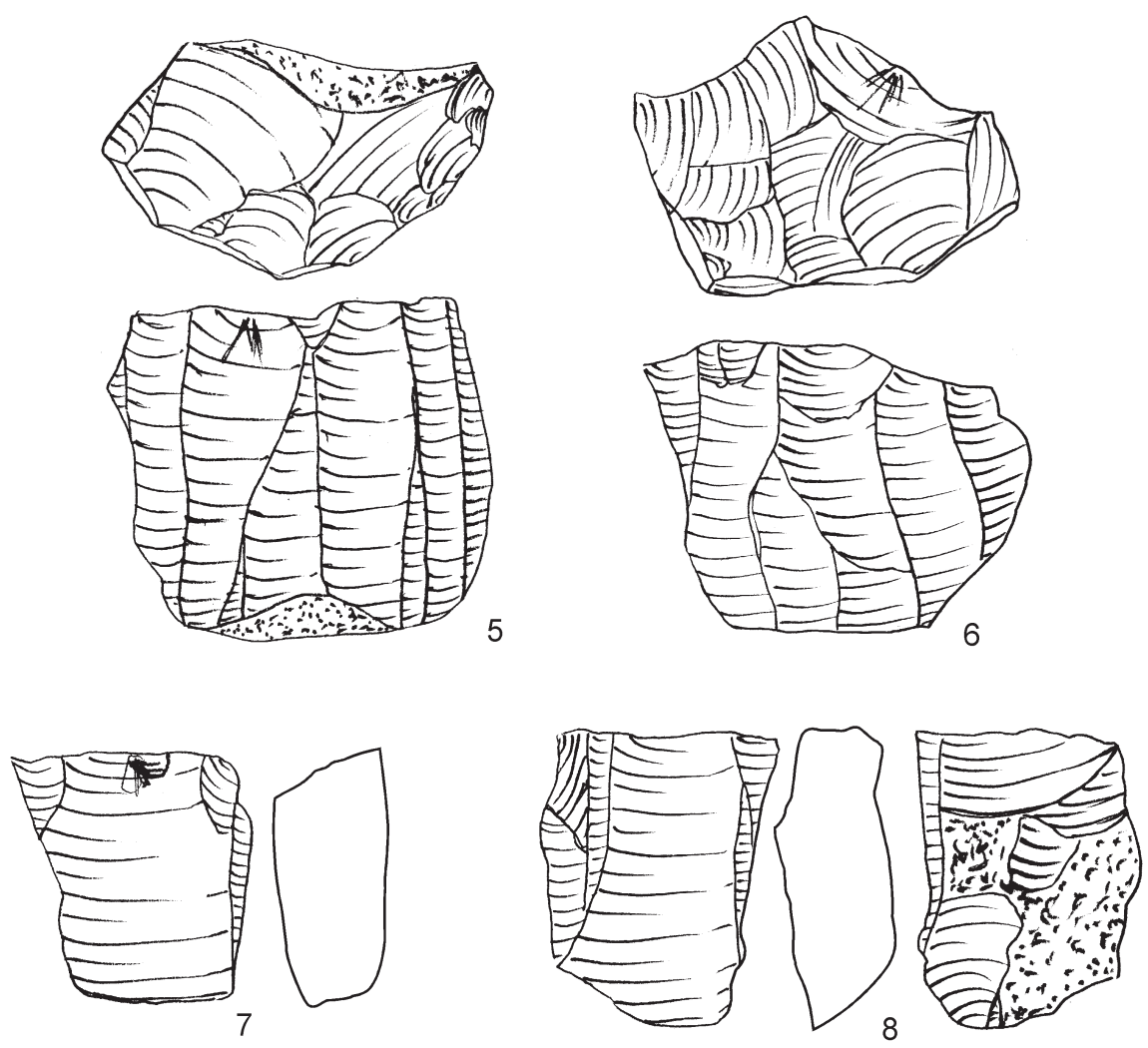

Fig. 14. Polgár-Piócási-dűlő. 1-8: cores from the early phase 


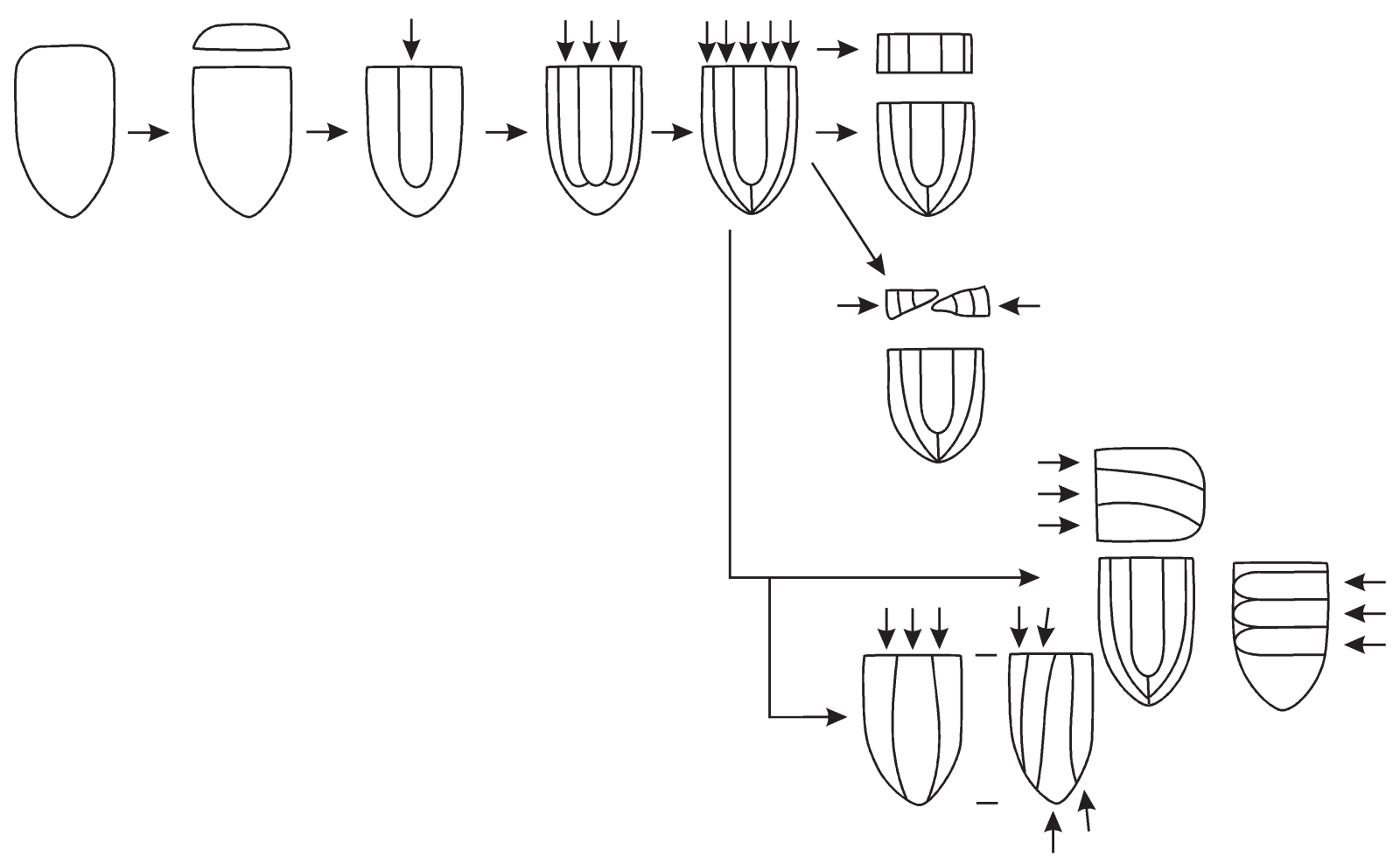

Fig. 15. Polgár-Piócási-dülő. Core reduction sequences

tures indicates that, besides cores, unworked nodules of raw material were also brought to the settlement. It is likely that at least some stages of the initial preparation were carried out in another, unexplored zone of the settlement.

In the early phase concretions were worked without preparation, using the cortical blade technique. Thick, cortical flakes were sometimes detached and the flaking surface was located on the narrower facet (Fig. 14.1). As reduction was continued the flaking surface was extended onto lateral sides (Fig. 14.2). In the case of cores from limnoquartzite the mode of reduction was similar (Fig. 14.3). The core reduction sequence is provided in Figure 15. When a core angle had to be corrected by detaching a tablet (Fig. 14.4) or trimming flakes from the platform edge, the core was shortened (Fig. 14.5, 6). As a rule reduction of single-platform blade cores was continued until the core was no longer productive (Fig. 14.7, 8). Less often, in order to fully exhaust an obsidian concretion the change-of-orientation of cores was used (3 specimens); the flaking surface was located on the core back (Fig. 16.1, 2) or on the platform (Fig. 16.3). Sometimes, the 180 degree change-of-orientation was used, the new platform was located in the proximal part of the core, and the flaking face on the core side. Such specimens, as a result, resemble double-platform cores (Fig. 16.4, 5). One core had a kind of a trimming edge on the core side (Fig. 16.6).

Chunks of limnoquartzite were, sometimes, bifacially reduced to become subdiscoidal cores (Fig. 16.7). Possibly, some of such cores were macrotools shaped by thick, bifacial retouch.

The late phase features yielded only 5 cores (including a fragment). The mode of core reduction - in case of both obsidian and limnoquartzite specimens - is similar to that used in the early phase, but the cores are smaller (Fig. 17.1-3). All the cores are almost cylindrical, with carefully prepared platforms and rounded flaking faces. One residual core, was transformed into a sub-discoidal specimen (Fig. 17.4). 

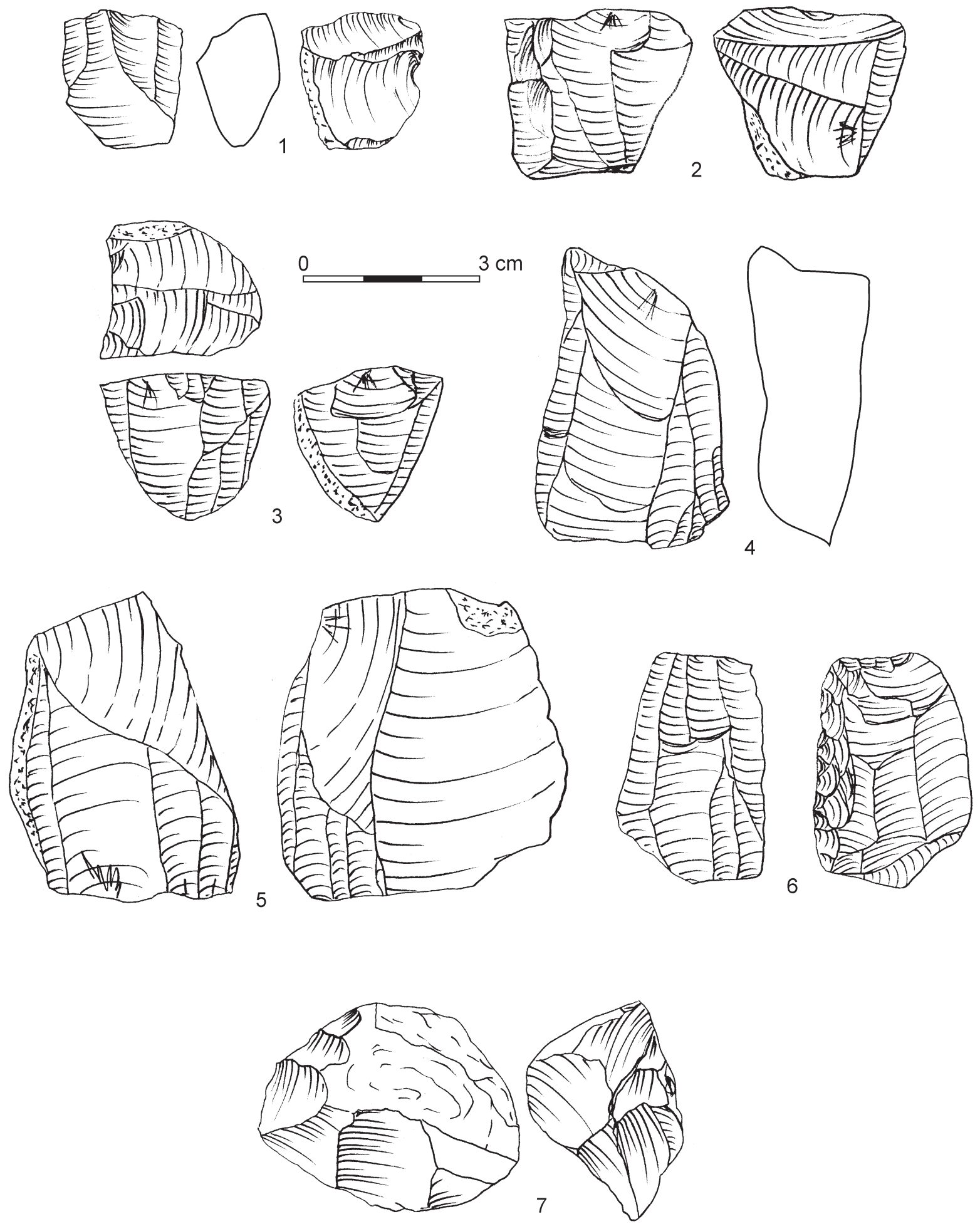

Fig. 16. Polgár-Piócási-dűlő. 1-7: cores from the early phase 

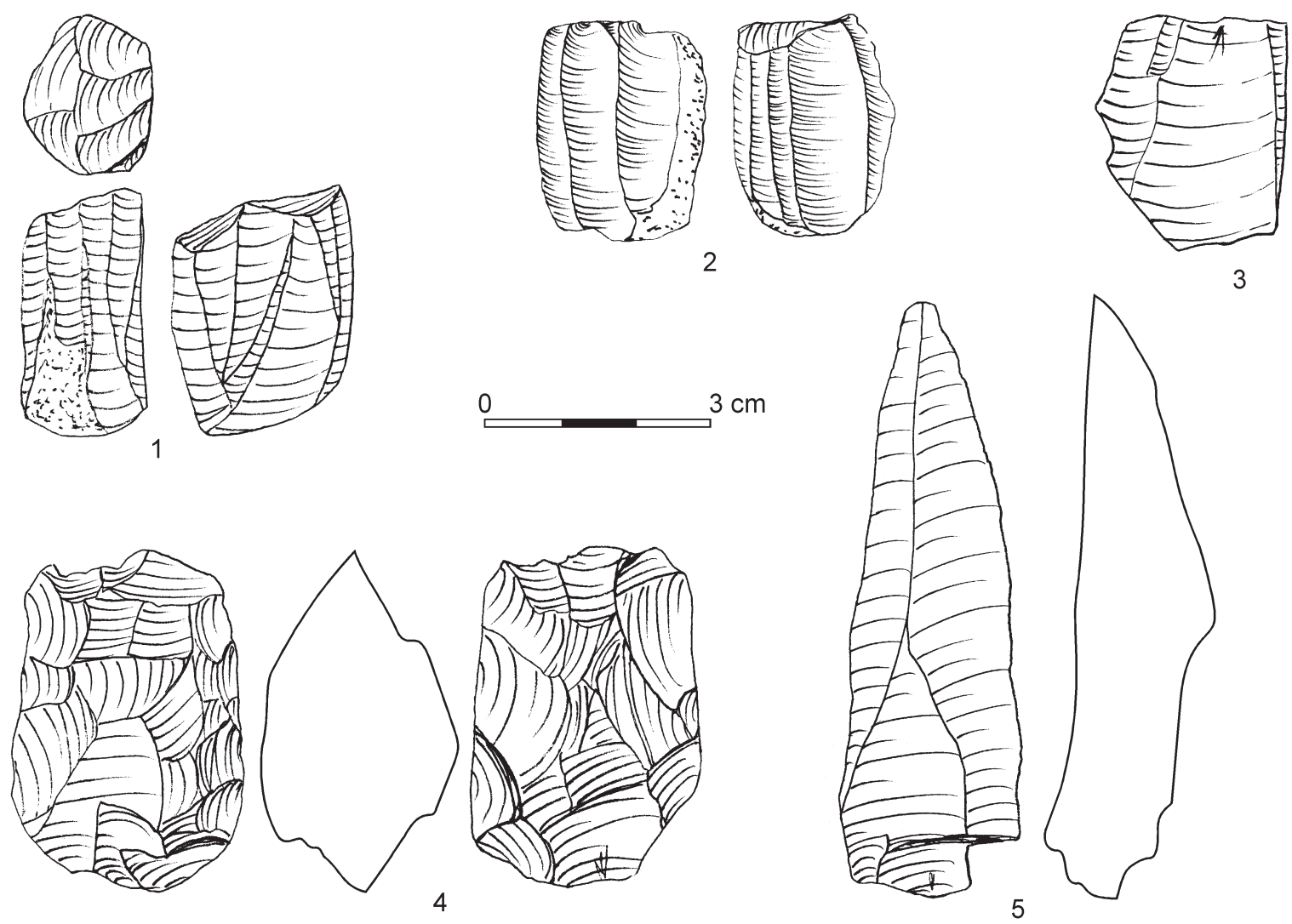

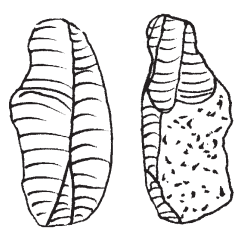

6

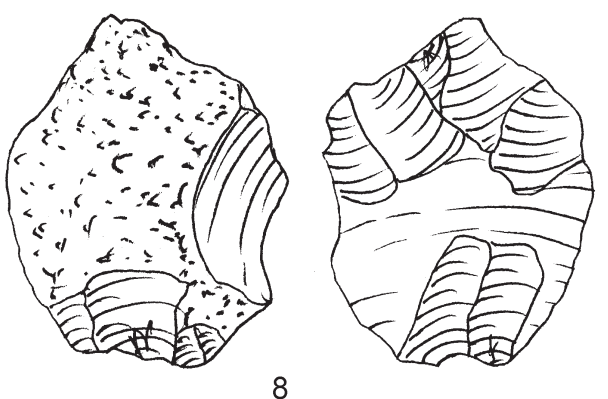

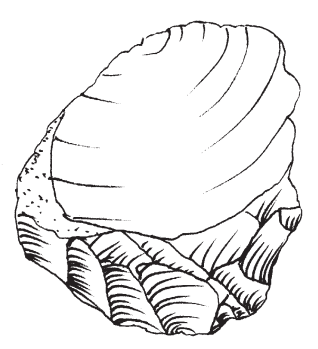

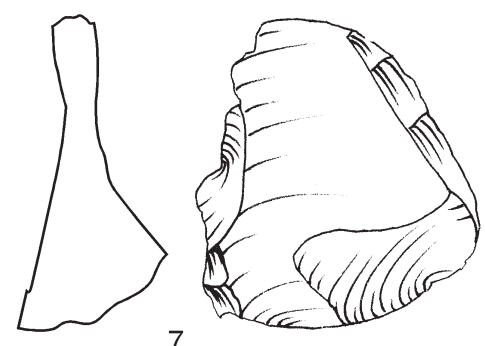

Fig. 17. Polgár-Piócási-dűlő. 1-4: cores from late phase features; 5: blade from late phase feature; 6-8: splintered pieces from the early phase; 9 : splintered piece from a late phase feature 


\subsubsection{Flakes}

The features of the early phase yielded 80 flakes which is $38.6 \%$ of the total inventory of this periode. The proportion of obsidian in this group of finds is $93.7 \%$, which corresponds to the average ratio of this type of raw material in the early phase of the Eastern Linear Pottery Culture.

The flake groups consist of both small specimens shorter than $18 \mathrm{~mm}$ in length, and larger flakes longer than $83 \mathrm{~mm}$. Flake width varies between 15 and $67 \mathrm{~mm}$, and thickness ranges from 2 to $23 \mathrm{~mm}$. The most numerous group consists of flakes that are 21 to $32 \mathrm{~mm}$ long and 19 to $30 \mathrm{~mm}$ wide. Broader specimens between 34 and 38 $\mathrm{mm}$ are fairly numerous. They may be associated with platform preparation.

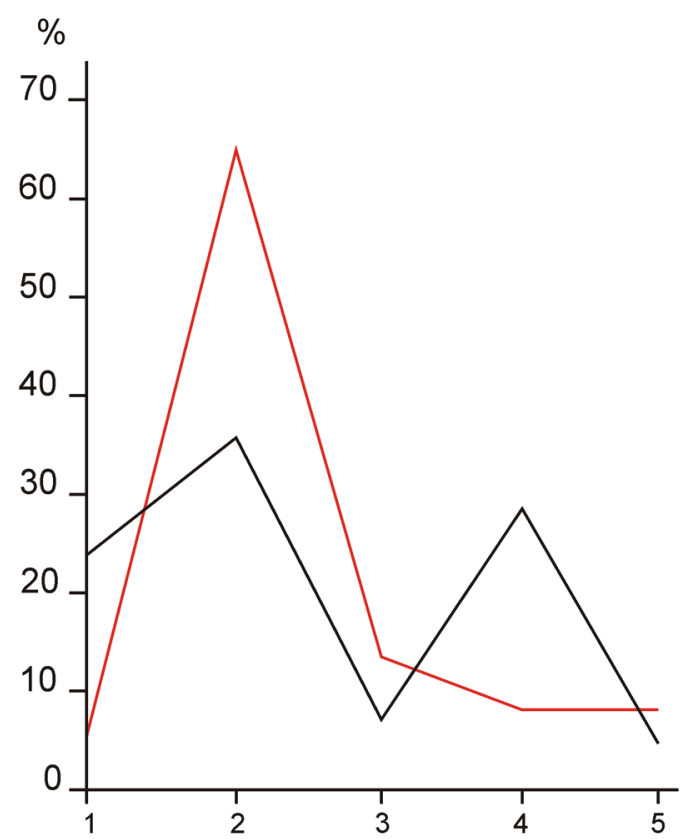

Fig. 18. Polgár-Piócási-dülö. Butts of flakes (black) and blades (red) in the early phase. 1: unprepared butts; 2 : formed by single blow; 3 : facetted; 4 : linear/punctiform; 5 : other

Flakes come from preliminary stages of core reduction (cortical flakes $-9 \%$, lateral cortex $-10 \%$ ) and from change-of-orientation (specimens with opposite scars $-6 \%$ and with perpendicular scars $-16 \%$ ). Analysis of dorsal patterns indicates a minor role of preliminary lateral preparation and retrimming (except for the shaping and rejuvenation of the platform). Moreover, 3 tablets and 6 flakes from centripetal platform preparation were registered. The relatively small proportion of specimens with blade dorsal scars ( 3 i.e. 3.7\%) suggests that although the use of preparation and retrimming was minor, considerable skill of knappers and good cleavage of the raw material allowed to continue blade production until a core was fully exhausted. Flakes with single-blow butts predominate $(35.7 \%)$ and flakes with unprepared butts are also fairly frequent $(23.8 \%)$. There are occasional flakes with facetted or dihedral butts (7.1 and $4.7 \%$ respectively). Relatively large is the group of flakes with punctiform (11.9\%) and linear butts (19.4\%) (Fig. 18).

Three small, thin splinters from obsidian can also be ascribed to the flake group that testifies to the acquaintance with the splintered technique.

Features dated to the late phase yielded 20 flakes; 7 were from limnoquartzite, and so, this type was more frequent in the late than in the early phase. Only 3 flakes (all of obsidian) are cortical. Flake length varies between 20 and $64 \mathrm{~mm}$, width between 14 and $55 \mathrm{~mm}$, and thickness between 2 and $26 \mathrm{~mm}$. These parameters do not differ from those in the early phase. The majority of flakes have single-blow butts. Unprepared or facetted butts do not occur. 


\subsubsection{Blades}

Fifty-eight blades were recovered from features dated to the early phase, 54 of which, i.e. $93.2 \%$, are obsidian specimens. Thus, the proportion of obsidian in this phase is similar to the average obsidian ratio at the site. Most specimens have been preserved as fragments. Only 15 blades, i.e. $26 \%$ are intact.

A high proportion of fragmented blades is often registered at Neolithic sites where blades were, probably, intentionally broken in order to obtain a straight profile. Usually, the thinnest, hinged distal part was broken off and, because of this, proximal and proximal-mesial parts occur most frequently in assemblages. The inventory of the early phase at Polgár-Piócási-dülő is consistent with this structure.

Blade length varies between 23 and $60 \mathrm{~mm}$, the most numerous group being those of $43-50 \mathrm{~mm}$. Width ranges from 6 to $27 \mathrm{~mm}$; specimens between 12 and $17 \mathrm{~mm}$ predominate (50\%) (Fig. 19).

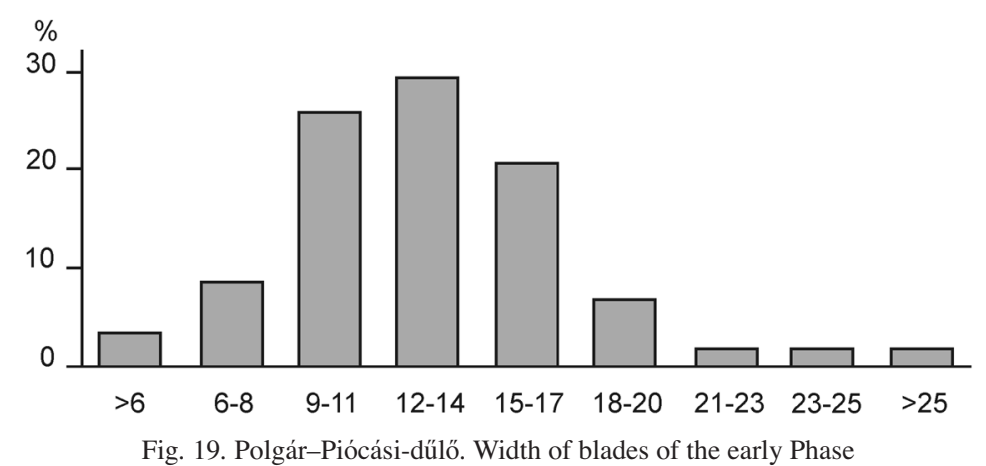

As a rule, blades were detached from single-platform cores or cores with the platform rejuvenated by detaching a tablet. As much as $64.8 \%$ are blades with a single-blow butt. Blades with a prepared butt are less frequent (13.5\%). Two blades were detached from cores with an unprepared platform (2 specimens i.e. 5.4\%) (Fig. 18).

Late phase features yielded 21 blades. Only one blade was made from limnoquartzite; its measurable parametres differ from those of obsidian blades (its length is $78 \mathrm{~mm}$, its width $21 \mathrm{~mm}$ - (Fig. 17.5); the butt is single-blow. The remaining blades are 18 to $36 \mathrm{~mm}$ long, 6 to $19 \mathrm{~mm}$ wide, and 1 to $5 \mathrm{~mm}$ thick. The majority of obsidian blades are equipped with single-blow ( 8 specimens), or facetted butts ( 7 specimens). One blade has a dihedral, and one has a punctiform butt. Cortical blades are absent; three specimens have lateral cortex. All the specimens show the same unidirectional dorsal pattern; scars are all from blades, regular, with parallel edges.

The comparison of blades from the two periods shows that blades from the early phase are larger and were more often detached from single-platform cores or cores with platforms rejuvenated by detaching a tablet. In the remaining features the proportion of obsidian blades with facetted butts is higher and, moreover, the values of length are more compact, similar to the length of cores. This was due either to an increasing standardization of blade production or to changes in the organization of production which meant that initial production stages took place beyond the investigated area.

\subsubsection{Splintered pieces}

Three obsidian splintered pieces were discovered in the features dated to early phase. One was made on a tablet (Fig. 17.7) and two bipolar specimens were shaped on cortical flakes (Fig. 17.6, 8).

Late phase features provided only one quadripolar splintered piece from a chunk of limnoquartzite (Fig. 17.9). 


\subsubsection{Chips}

Eleven obsidian chips were discovered in features dated to the early phase, including 8 from feature 132 . 25 very small chips $(2-5 \mathrm{~mm})$ were identified during the wet sieving of the filling of feature 132 . These chips are not included in the tables because the fillings of other features were not wet sieved. The smallest chips (2-3 mm) were debris of tool production and/or rejuvenation. One microburin shaped by a flat transversal scar was obtained by wet sieving. Retouch of the lateral notch seems rather fresh. The absence of microburin technique in Neolithic assemblages in the Great Hungarian Plain and fresh retouch suggest the rather accidental character of this artifact.

Five chips were found in features associated with the late phase (including 4 specomens found during wet sieving). Three of them are obsidian chips and 2 from limnoquartzite. Chips obtained during wet sieving are very small and resulted from tool retouch and/or rejuvenation.

\subsubsection{Retouched tools}

A total of 50 specimens were recovered: 35 specimens from the early phase features and 15 specimens from the late phase features. In the early phase blanks for the production of retouched tools were between 19-69 $\mathrm{mm}$ long; there were 10 specimens longer than $45 \mathrm{~mm}$. The lengths of tools brought to light from the late phase features varies between 12 and $60 \mathrm{~mm}$, but only one tool was longer than $45 \mathrm{~mm}$.

\subsubsection{Tools from the early phase}

In the early phase, the raw material used for tool production was exclusively obsidian. The most numerous group consists of retouched flakes (11 specimens), followed by blades with lateral retouch (10). Less numerous were end-scrapers (4), denticulated-notched tools (4), truncations (3), and side-scrapers (2). Only one functional tool was found, which was a sickle insert combined with an end-scraper.

Flakes (11)

All specimens (with the exception of one specimen made from radiolarite) were made from obsidian.

In terms of the location of retouch the following groups were distinguished:

- 5 specimens with unilateral retouch: two fragments with continuous semi-steep retouch (Fig. 20.1, 2), and three intact specimens with partial unilateral, irregular, fine retouch (Fig. 20.3-5);

- 2 specimens still in the initial reduction stage with partial distal retouch: semi-steep (Fig. 20.6) or steep (Fig. 20.7);

- a cortical flake with steep distal retouch (Fig. 20.9), which could be a Palaeolithic intrusion;

- a fragment of a large flake with lateral retouch modified into a splintered piece (Fig. 20.8);

- 2 specimens with inverse retouch: one has a distal concave retouch, the other one a lateral simple retouch (Fig. 21.1, 2).

Blades with lateral retouch (10)

All these blades were made from obsidian:

- 3 macroblades with discontinuous fine retouch on both lateral sides (Fig. 21.3-5);

- a fragment of a macroblade with continuous semi steep retouch (Fig. 21.6);

- a blade-flake with partial, alternate, irregular retouch (Fig. 21.7);

- 3 fragments of mediolithic blades with bilateral retouch (Fig. 21.8-10);

- a fragment of a mediolithic blade with continuous unilateral semi steep retouch (Fig. 21.11);

- a mediolithic blade with partial unilateral inverse retouch (Fig. 22.1).

End-scrapers (4)

The following types were represented:

- a specimen on a large, obsidian blade with a convex, steep front (Fig. 22.2); 

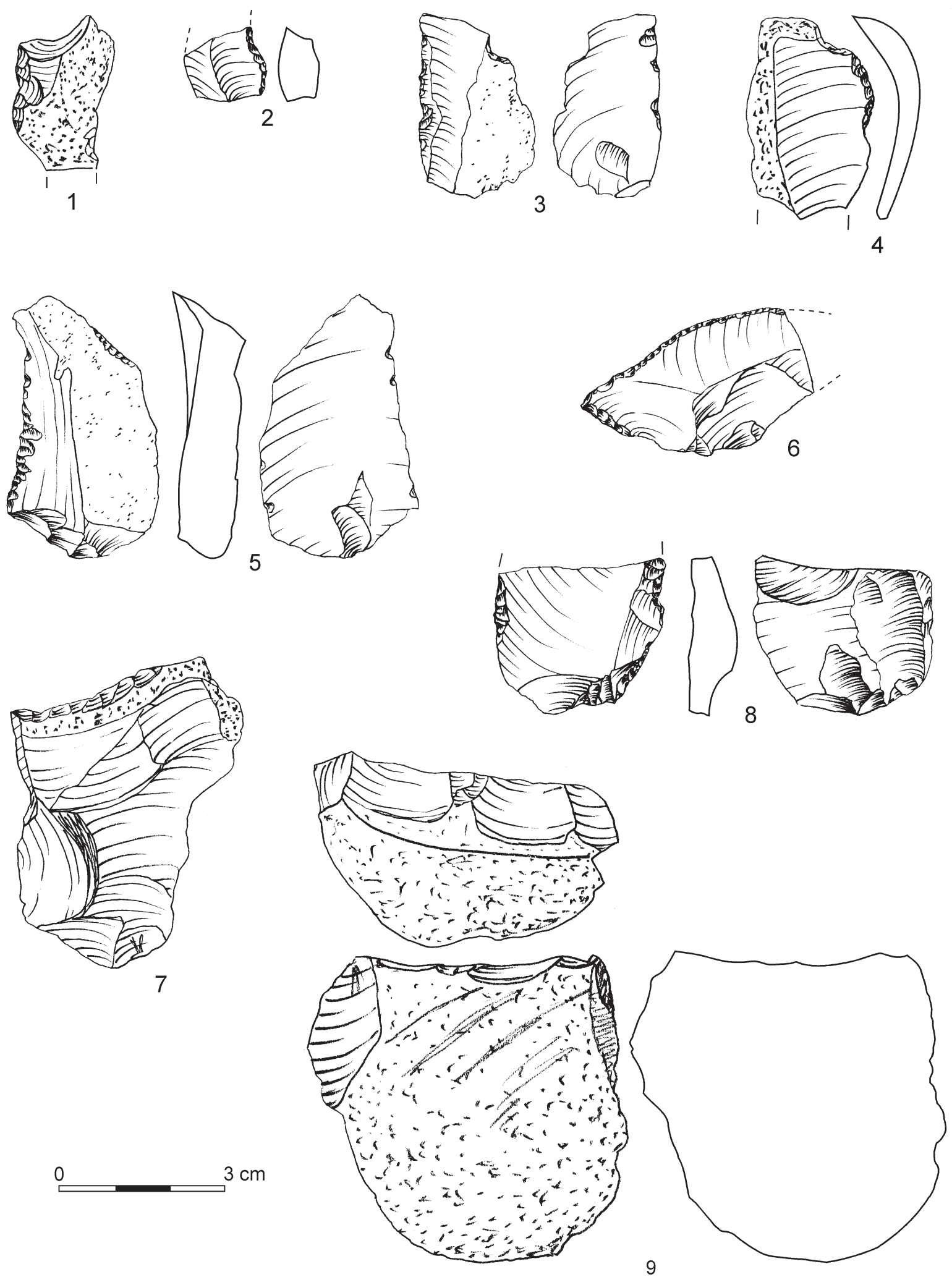

Fig. 20. Polgár-Piócási-dülő. 1-9: retouched flakes from the early phase 

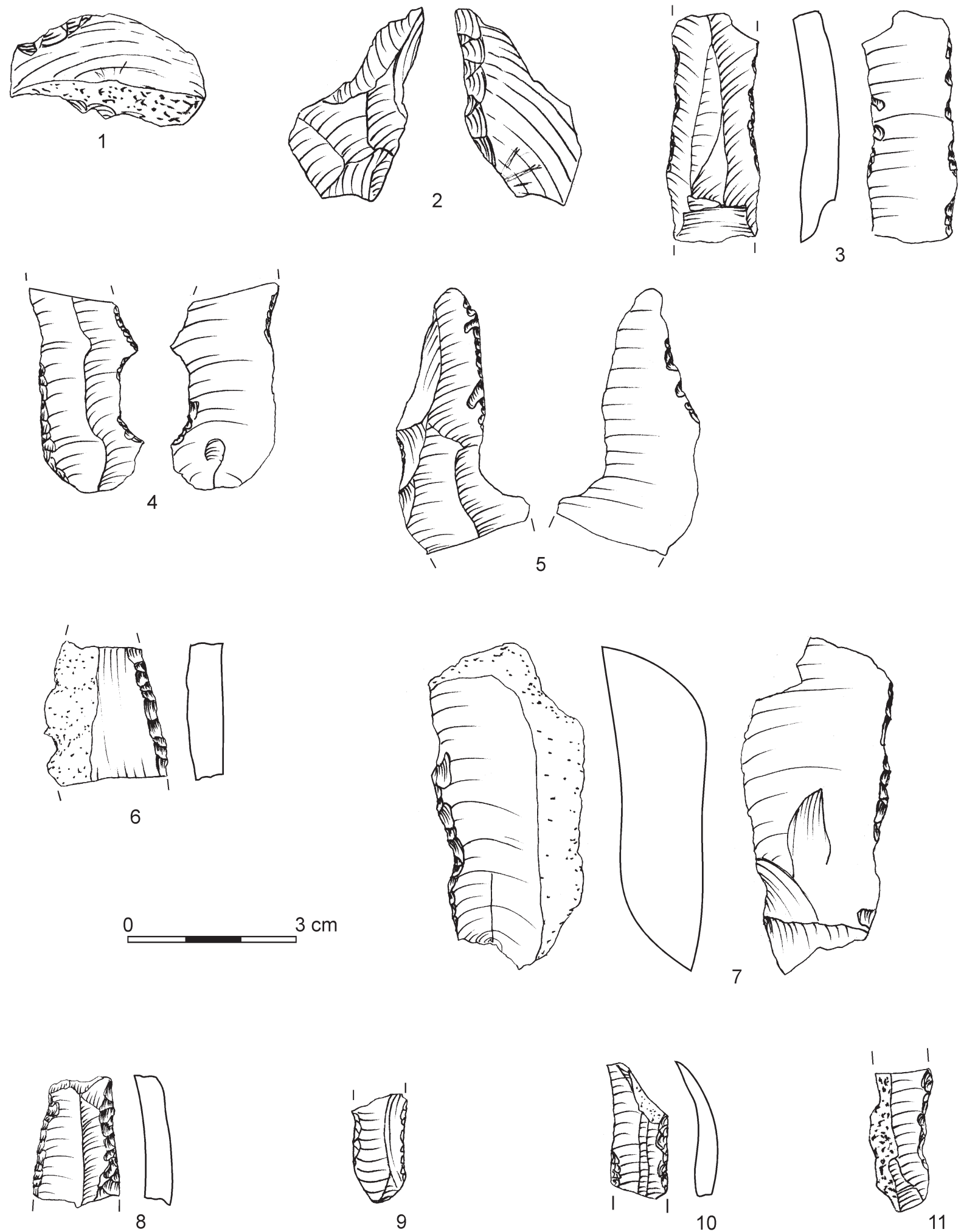

Fig. 21. Polgár-Piócási-dűlő. 1-2: retouched flakes from the early phase; 3-11: retouched blades from the early phase 

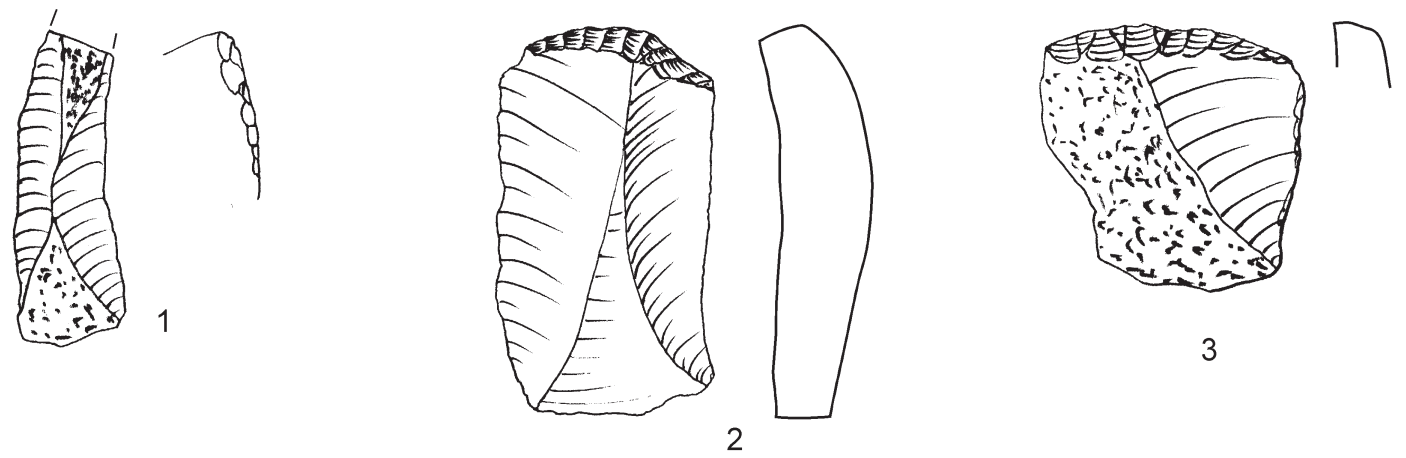

3
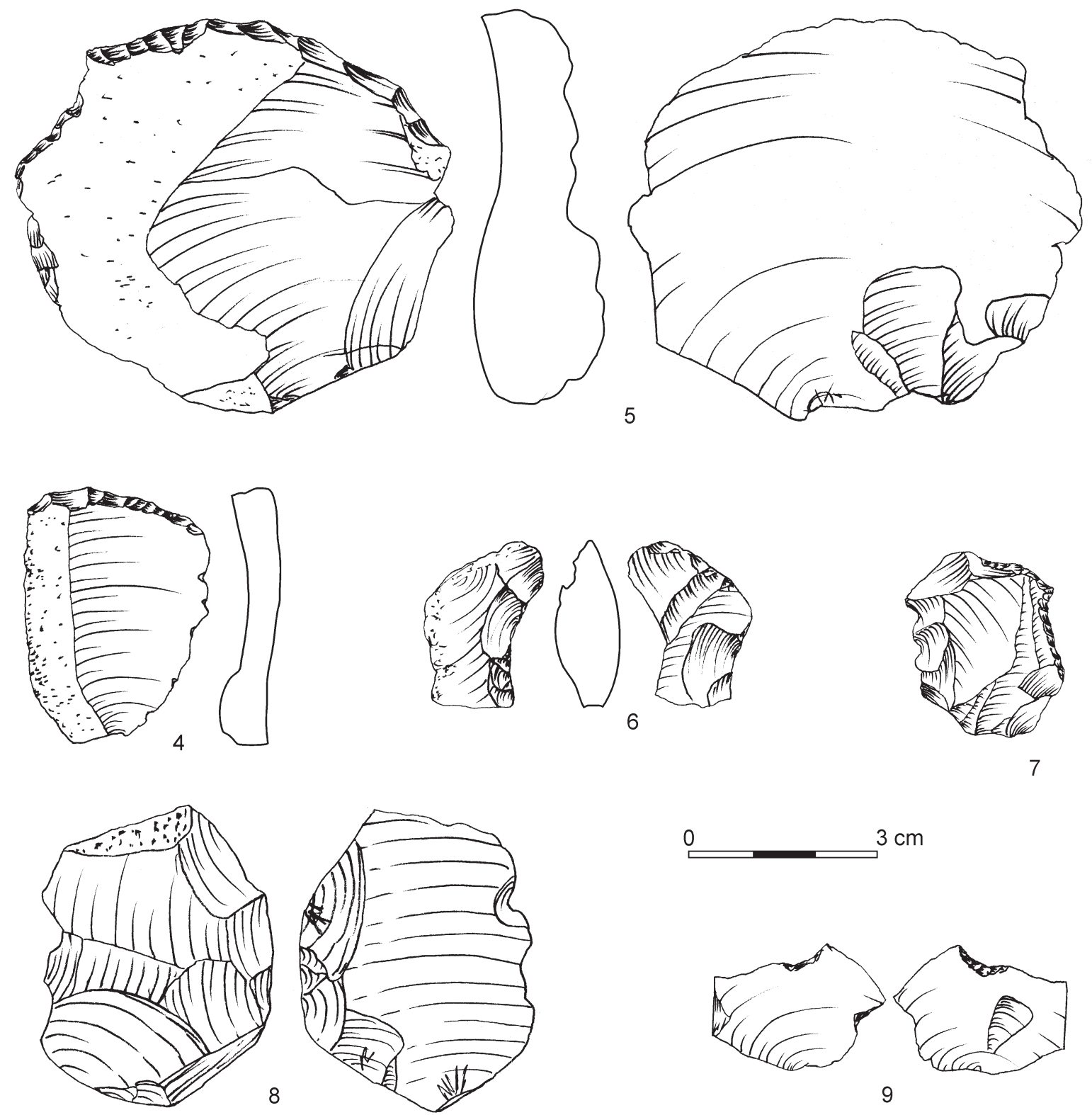

0 $3 \mathrm{~cm}$

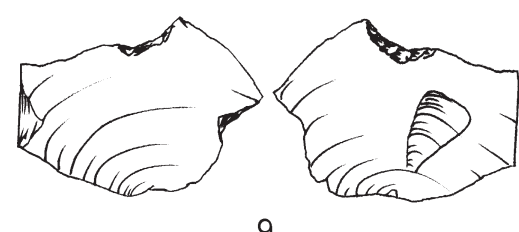

Fig. 22. Polgár-Piócási-dủlő. 1: retouched blade; 2-5: end-scrapers, 6-9: denticulated-notched implements from the early phase 
two end-scrapers on obsidian blade-flakes with lateral cortex, the fronts are weakly convex and steep (Fig. 22.3, 4);

- an end-scraper on an obsidian macroflake with a strongly rounded, steep front (Fig. 22.5).

Denticulated-notched tools (4)

The boundary between this group and the group of retouched flakes is blurred. All the tools were made from obsidian. The following specimens have been ascribed to denticulated-notched tools:

- a flake with lateral inverse notched retouch (Fig. 22.6);

- a flake with lateral denticulated retouch, lateral notched retouch, and transversal retouch (semi-steep and denticulated - Fig. 22.7);

- a robust flake with lateral denticulated inverse retouch (Fig. 22.8);

- a fine flake with a distal notch, bifacially shaped (Fig. 22.9).

Truncations (3):

- Two specimens made on fragments of regular, mediolithic obsidian blades: one with an oblique truncation (Fig. 23.1), and the other with a transversal truncation (Fig. 23.2).

- There was also a cortical flake from obsidian, with an oblique truncation shaped by semi-steep retouch (Fig. 23.3).

Side-scrapers (2)

Both side-scrapers were made from obsidian:

- a lateral side-scraper, weakly convex, on a large flake with semi-steep retouch (Fig. 23.4);

- a simple lateral side-scraper on a large cortical flake, also shaped by semi-steep retouch (Fig. 23.5).

Harvesting tool (1):

A sickle insert on an obsidian blade end-scraper with oblique gloss in the proximal-lateral part (Fig. 23.6).

6.2.6.2. Tools from late phase features

Fifteen tools were identified from the late phase features at the site.

Retouched flakes (2):

- a triangular flake with bilateral alternate inverse retouch (from radiolarite - Fig. 23.7);

- a cortical obsidian flake with steep distal retouch. A scar on the lateral edge resembles a burin scar which is earlier than the transversal retouch (Fig. 23.8).

Retouched blades (4)

All the specimens are made from obsidian:

- a mesial fragment of a regular blade with alternate retouch and strong use-wear on both edges (microscars and oblique striations on one edge and crushing on the opposite edge - Fig. 24.1);

- a mediolithic blade with alternate retouch (obverse continuous, inverse discontinuous, flat) (Fig. 24.2);

- a mediolithic blade with unilateral semi steep retouch on a section of the edge (Fig. 24.3);

- a fragment of a sub-crested blade with fine, partially inverse retouch on one edge (Fig. 24.4).

End-scrapers (3):

- two end-scrapers on mediolithic blades: one on a regular, narrow, obsidian blade with a convex steep front (Fig. 24.5), and the other on a sub-crested blade from limnoquartzite; the front is asymmetrical, weakly convex; use-wears in the form of short transversal striations on the edge (Fig. 24.6);

- a short obsidian end-scraper with lateral retouch and a convex front (Fig. 24.7). 


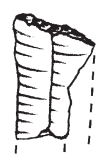

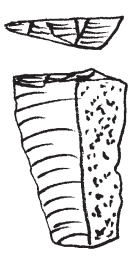

2
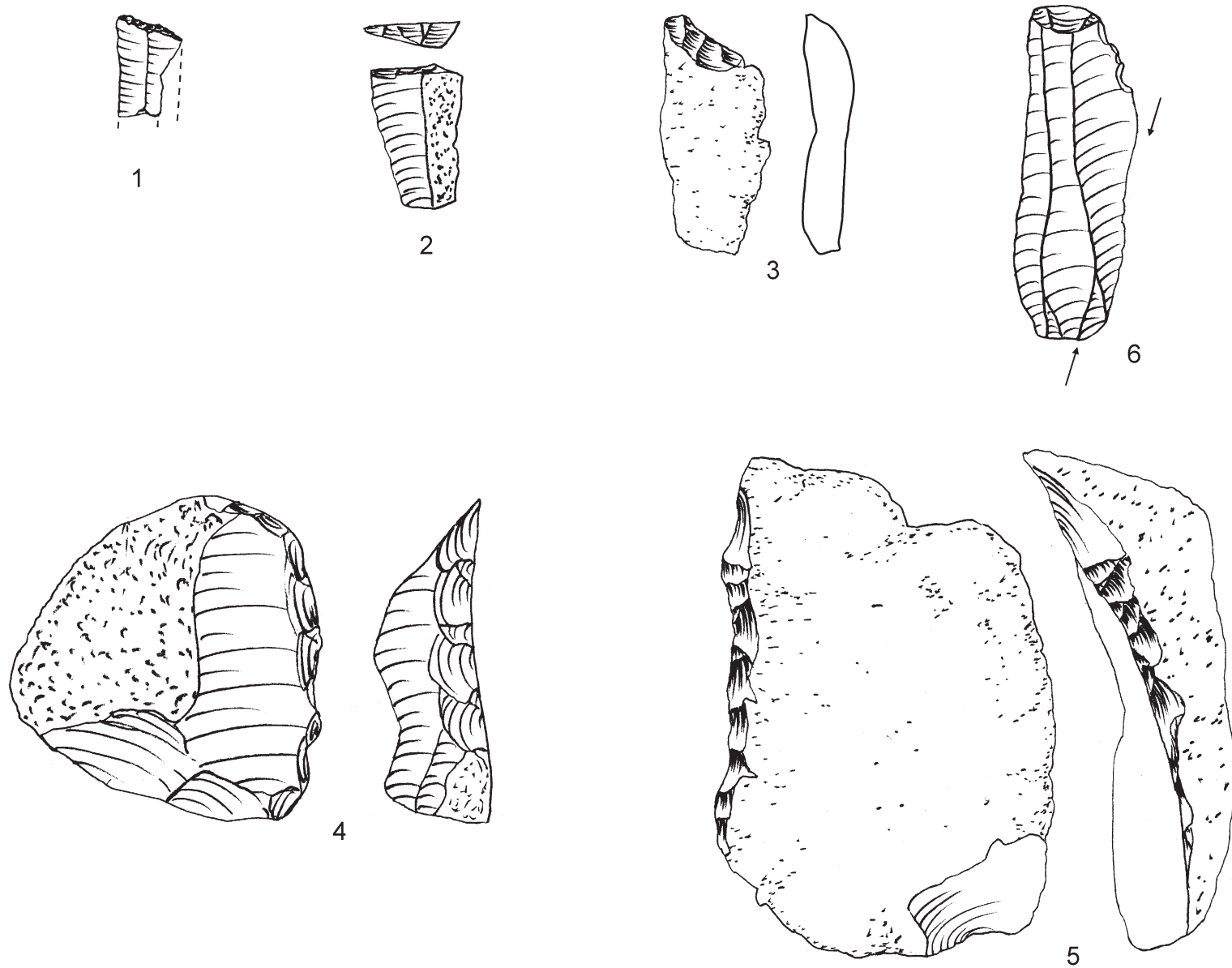

0 $3 \mathrm{~cm}$
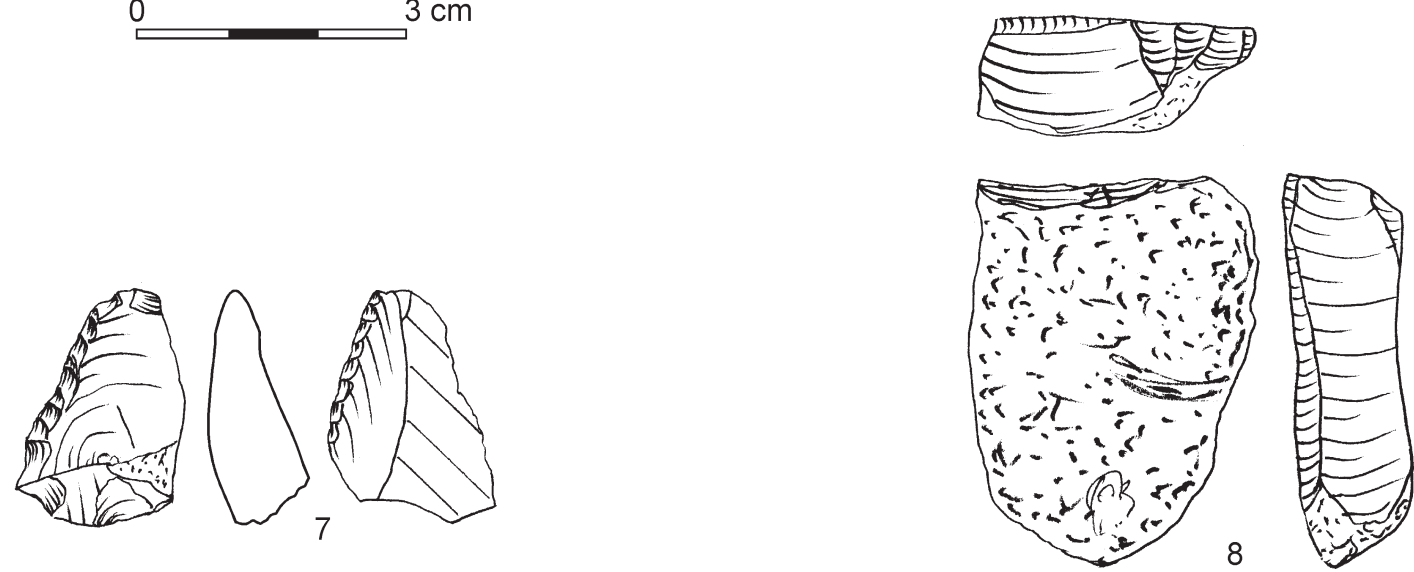

Fig. 23. Polgár-Piócási-dűlő. 1-3: retouched truncations; 4-5: side-scrapers; 6: sickle insert on end-scraper from the early phase; 7-8: retouched flakes from late phase features 
Burin (1)

The only burin was made on a fine flake from limnoquartzite; with denticulated distal retouch and a short, lateral burin blow ( Fig. 24.8).

Perforator/bec (1)

A bec on an obsidian flake with the tip shaped by two adjacent notches (Fig. 24.9).

Functional tools:

- a sickle insert on the medial fragment of a broken blade; sickle gloss on the break (limnoquartzite - Fig. 24.10);

- a fragment of a sickle insert on an irregular blade from limnoquartzite; the lateral-distal gloss is almost obliterated by a subsequent strong rounding of the edge (Fig. 24.11);

- a double sickle insert on the medial fragment of a blade: use-wears on both sides subsequent to the breaking of the distal part (Fig. 24.12);

- a sickle insert (?) on an obsidian macroblade: use-wears were recorded during the analysis by Dr. Jolanta Kamińska-Szymczak with the use of small magnifications (20-59x). The observations were documented by photography (Fig. 25.1-4). Macroscopic and microscopic observations revealed: a) on the right edge, both on the ventral and dorsal side, the section of the edge is matt, with micro-scars (Fig. 25.1, 2); b) the tip of the blade had broken off during use or directly after (fresh break); c) on the dorsal side of the blade, on its distal part, pseudo-retouch can be seen - possibly traces left by hafting; d) numerous striations were observed parallel to the edge, on the dorsal and ventral sides (Fig. 25.3, 4). The above observations indicate that both lateral edges of the blade were utilized. It seems that the initial working edge was the right edge with the matt section observable under microscope. To sum-up: both lateral edges of the obsidian blade show use-wears. The type of wears and their location point to a contact with soft plant material. The traces recorded in the distal part of the blade suggest hafting, probably oblique (?) (Fig. 24.13).

When tools from the early phase are compared to tools from the later features, must be kept in mind that the number of specimens in the later assemblage is much smaller than the number of tools in the early phase. It seems that the tools in the second inventory were more often made from raw materials other than obsidian. Moreover, in the later group of features, tool categories that were absent in the first assemblage, such as burins and perforators, are represented (although by single items). Sickle inserts, too, are more numerous in the later group of features (although this may result from difficulties in identifying use-wears associated with this function on obsidian artefacts).

\subsection{Ground stone and polished stone artefacts}

The collection from Polgár-Piócási-dülő consisted of 119 ground stone and 4 polished stone artefacts. Ground stones can be divided into three functional-morphological categories:

a) fragments of artefacts with polished surfaces or flakes from such artefacts,

b) lower (passive) and upper (active), quernstones or their fragments,

c) grinders, hammerstones and grinders-hammerstones.

The specimens in group (a) are made from sienite, or similar volcanic rocks, sandstone and breccia.

Quernstones in group (b) were as a rule made from sienite, or similar volcanic rocks, sandstone, limestones; single specimens were made from andesite, tuffit and breccia also.

Hammerstones and grinders (group c) were made from quartz and limnoquartzite. 


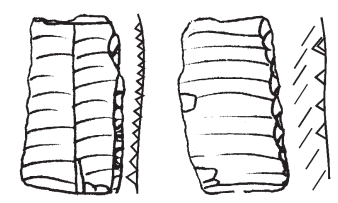

1
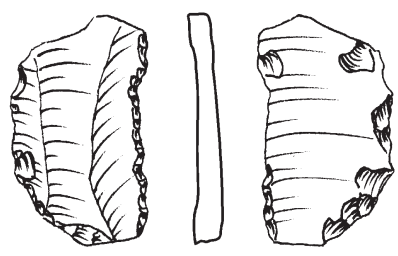

2

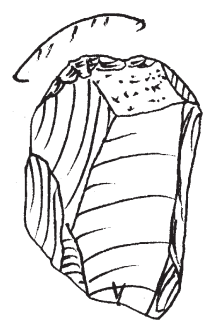

6

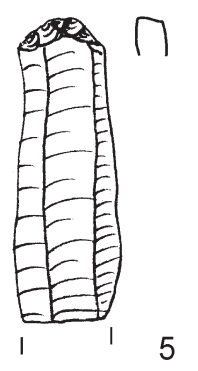

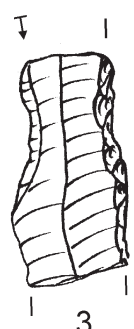

3
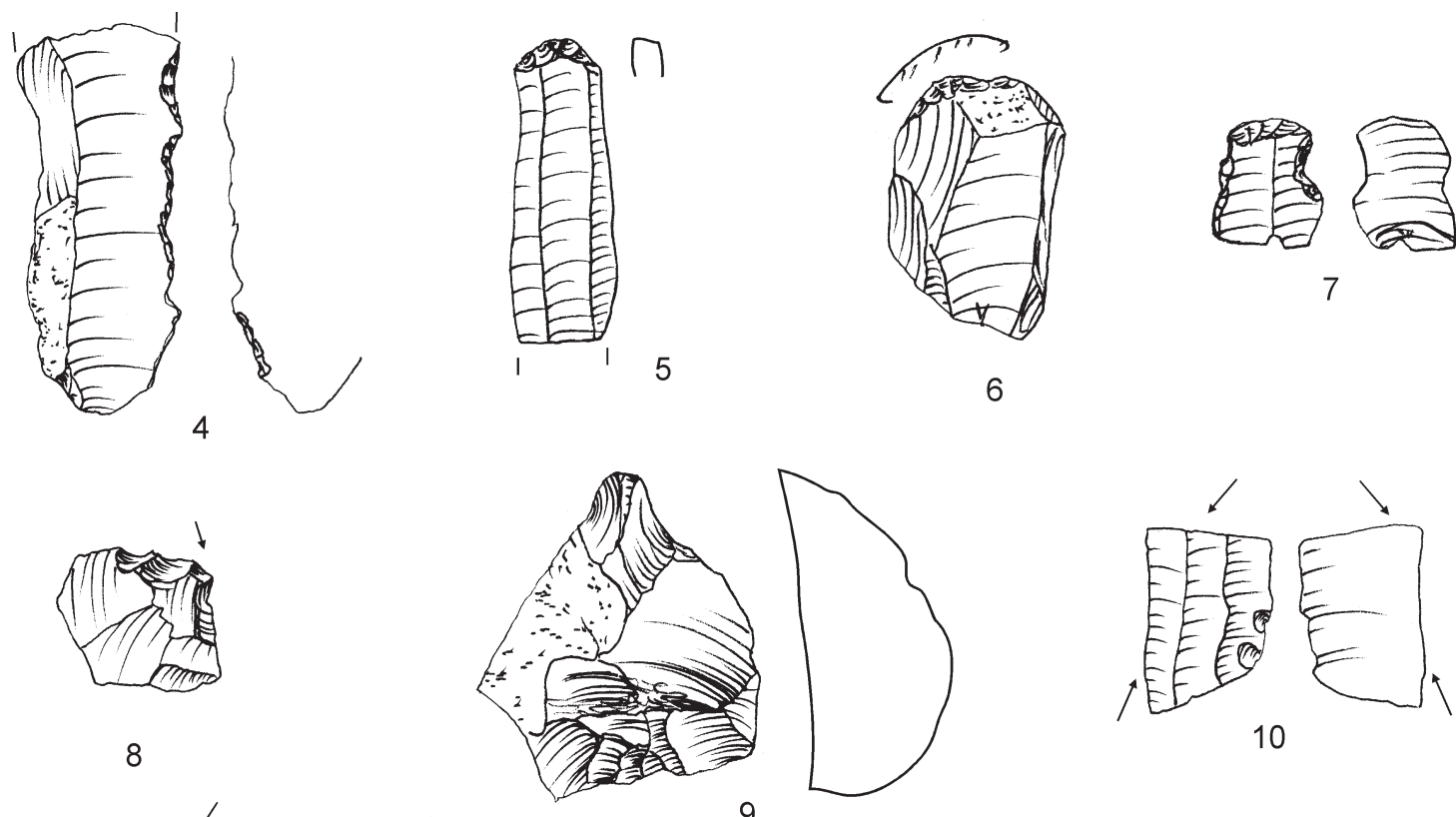

8

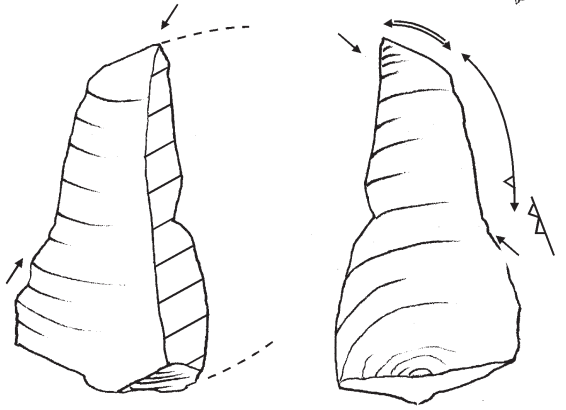

9

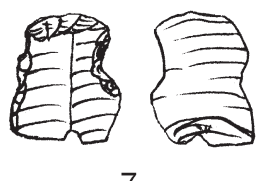
7

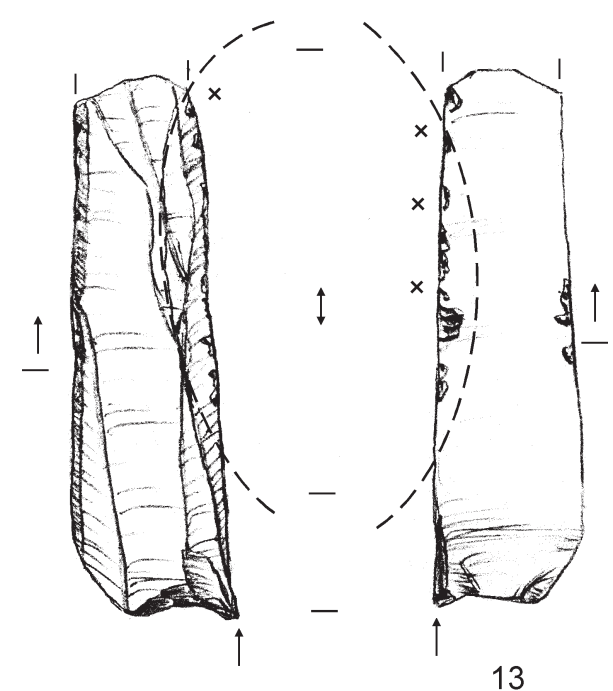

Fig. 24. Polgár-Piócási-dűlő. 1-4: retouched blades; 5-7: end-scrapers; 8: burin; 9: bec, 10-13: sickle inserts from late phase features 


\subsubsection{The early phase assemblage}

The features in the early phase yielded 50 ground stone and 1 polished stone artefacts and fragments (including two lumps of dyes). All the ground stone implements are strongly damaged; they were probably intentionally broken after they had been intensively used for a long time. Only spherical grinders and hammerstones have been preserved undamaged.

Group (a) - fragments with working surfaces:

- fragments with one polished surface - 7;

- fragments with two polished surfaces - 10;

- flakes from ground stone implements - 15;

- indeterminate fragments of ground stone implements -3 .

Group (b) consists of quernstones - complete and fragments:

- a fragment of an upper grinding stone: subrectangular, loaf-shaped, with longitudinal and latitudinal fractures; the cross-section is concave-convex (Fig. 26);

- a fragment with three polished surfaces used in succession, probably of an intensively used upper "loafshaped" grinding stone (Fig. 27);

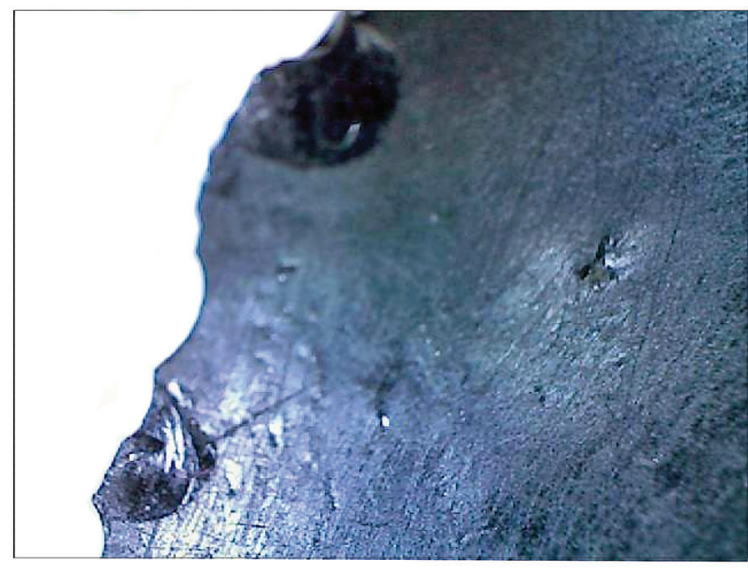

1

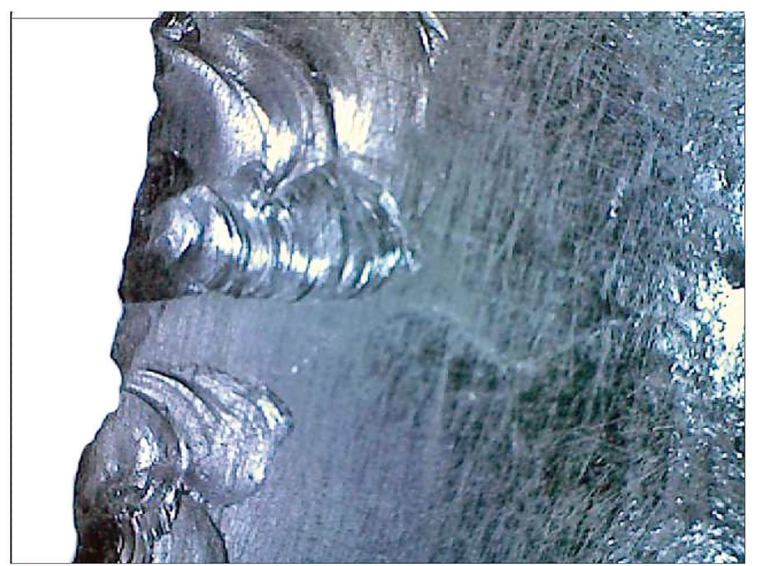

3

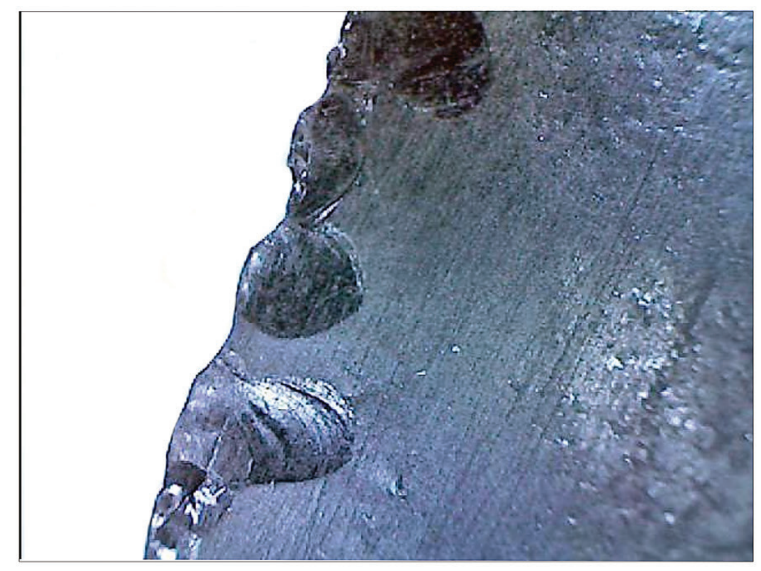

2

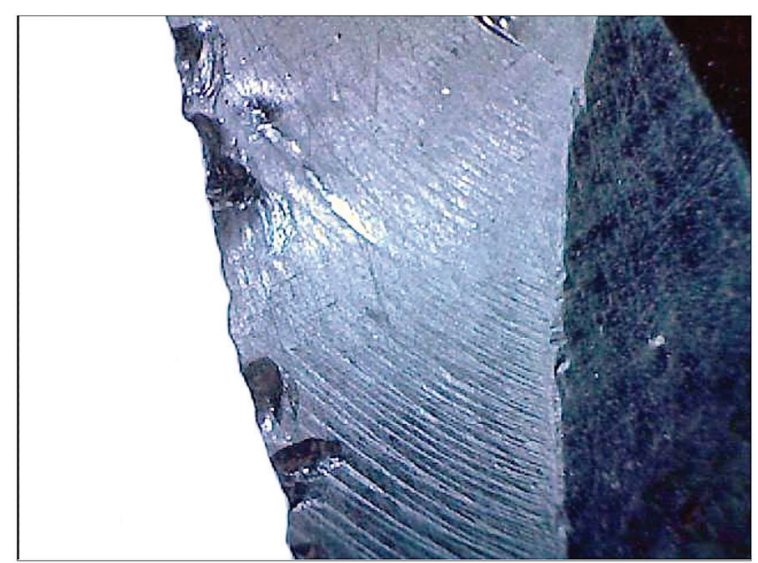

4

Fig. 25. Polgár-Piócási-dülő. 1-3: Use-wears on the ventral side of the obsidian blade (with linear striations parallel to the working edge and micro-scars in the middle part of the edge (Fig. 24.13); 4: Dorsal side of the obsidian blade: linear microstriations run parallel to the edge (traces perpendicular to the edge are not functional, but represent the original structure of obsidian). 
- fragments of lower grinding stones (Fig. 28-29); one of the fragments is strongly worn, bi-concave (Fig. 30) - 5 specimens.

Moreover, grinders and hammerstones (group c) were recovered, used for working hard materials: stone and others and for crushing mineral dyes:

- grinders/spherical hammersone - 2 specimens (Fig. 31);

- hammersones with two edges -2 specimens.

Polished implements:

- a small axe (4.2 cm long, $2.8 \mathrm{~cm}$ broad), subrectangular in shape; the cutting edge is convex, asymmetrical in profile, the face is thin, asymmetrical; the cross-section is convex-concave; the axe was made from white tuffit (Fig. 32.1);

- a fragment of a flake from a polished implement.
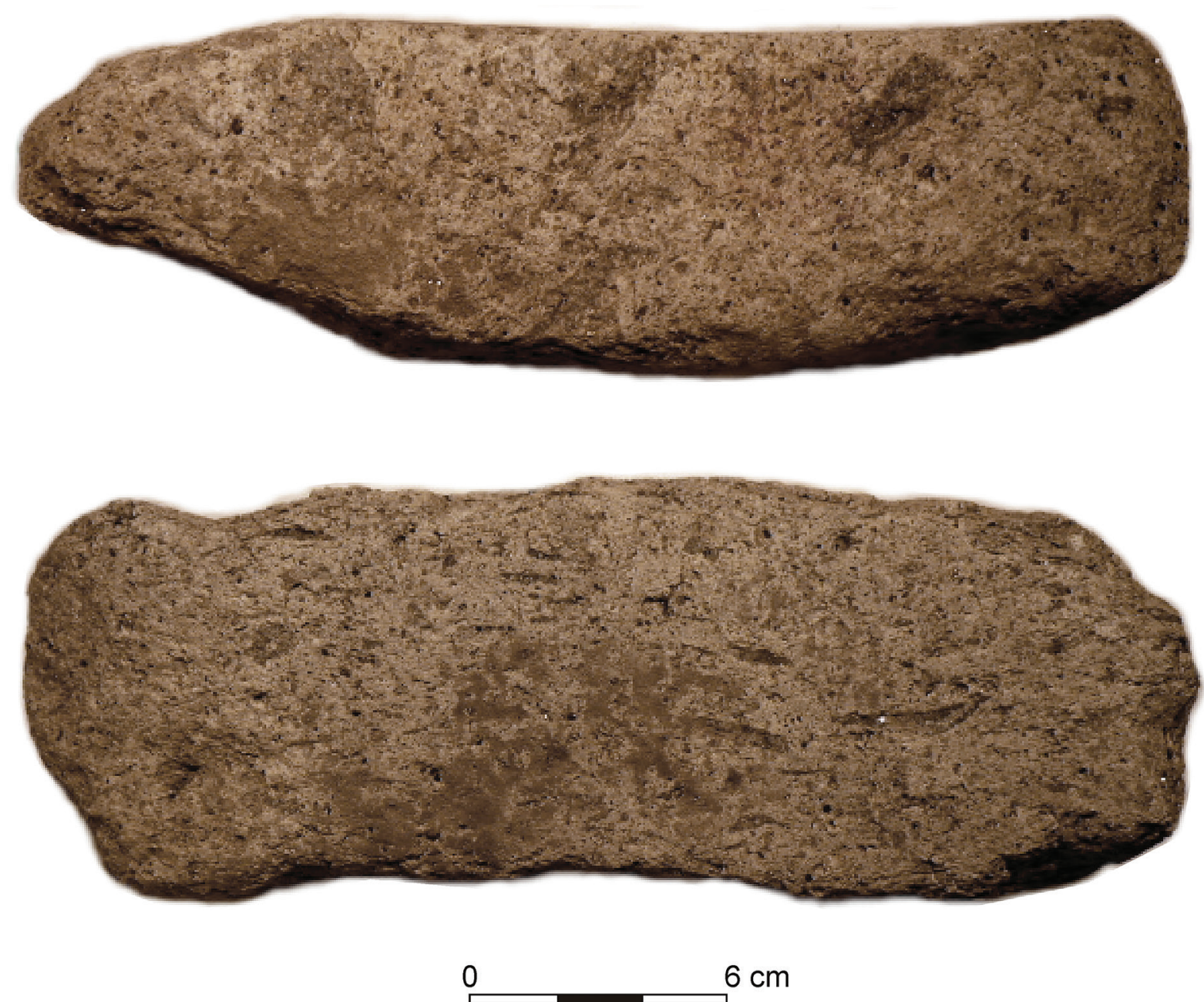

Fig. 26. Polgár-Piócási-dűlő. Fragment of quernstone (early phase) 


\subsubsection{The late phase assemblage}

From the later features 72 ground stone and polished stone artefacts were recovered.

To group (a) - fragments with working surfaces - belong:

- 5 fragments with one polished surface;

- a fragment of a thin stone plaquette, bifacially polished, with a polished edge;

- 5 fragments, bifacially polished;

- 5 flakes from ground stones (Fig. 33);

- two indeterminate fragments of ground stones;

- a fragment of a stone with striations from polishing (probably used for working the edges of polished stone or bone tools) (Fig. 34);

- two intact lower grinding stones with concave active surfaces: one is subrectangular with rounded corners, the sides are retouched, asymmetrical in the horizontal cross-section (one end is thicker) (length $-43 \mathrm{~cm}$, width - 16-22 cm, thickness $-7.5-14.2 \mathrm{~cm}$, Fig. 35); the other specimen is larger, more

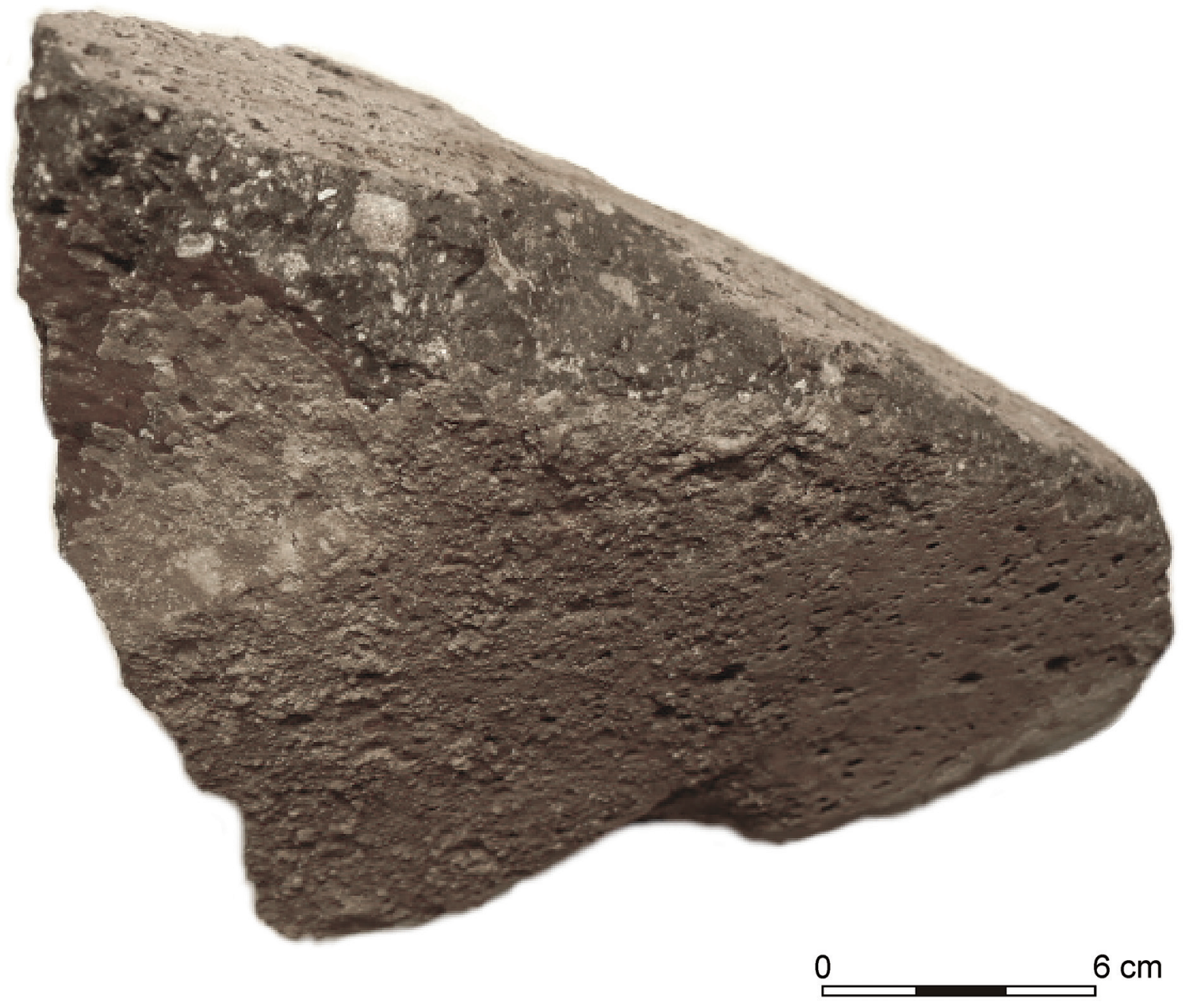

Fig. 27. Polgár-Piócási-dủlő. Fragment of quernstone (early phase) 

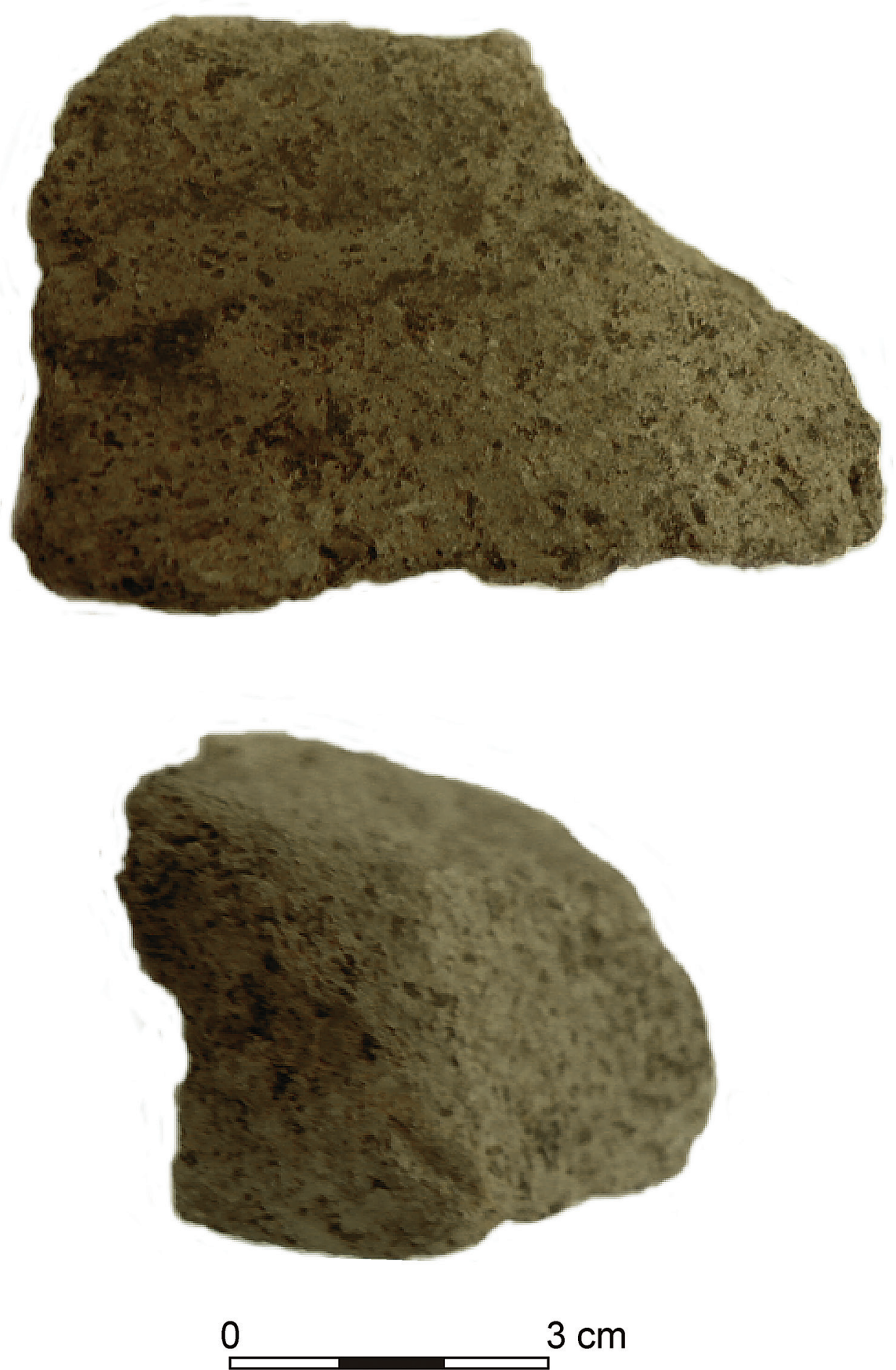

Fig. 28. Polgár-Piócási-dűlő. Fragment of quernstone (early phase) 


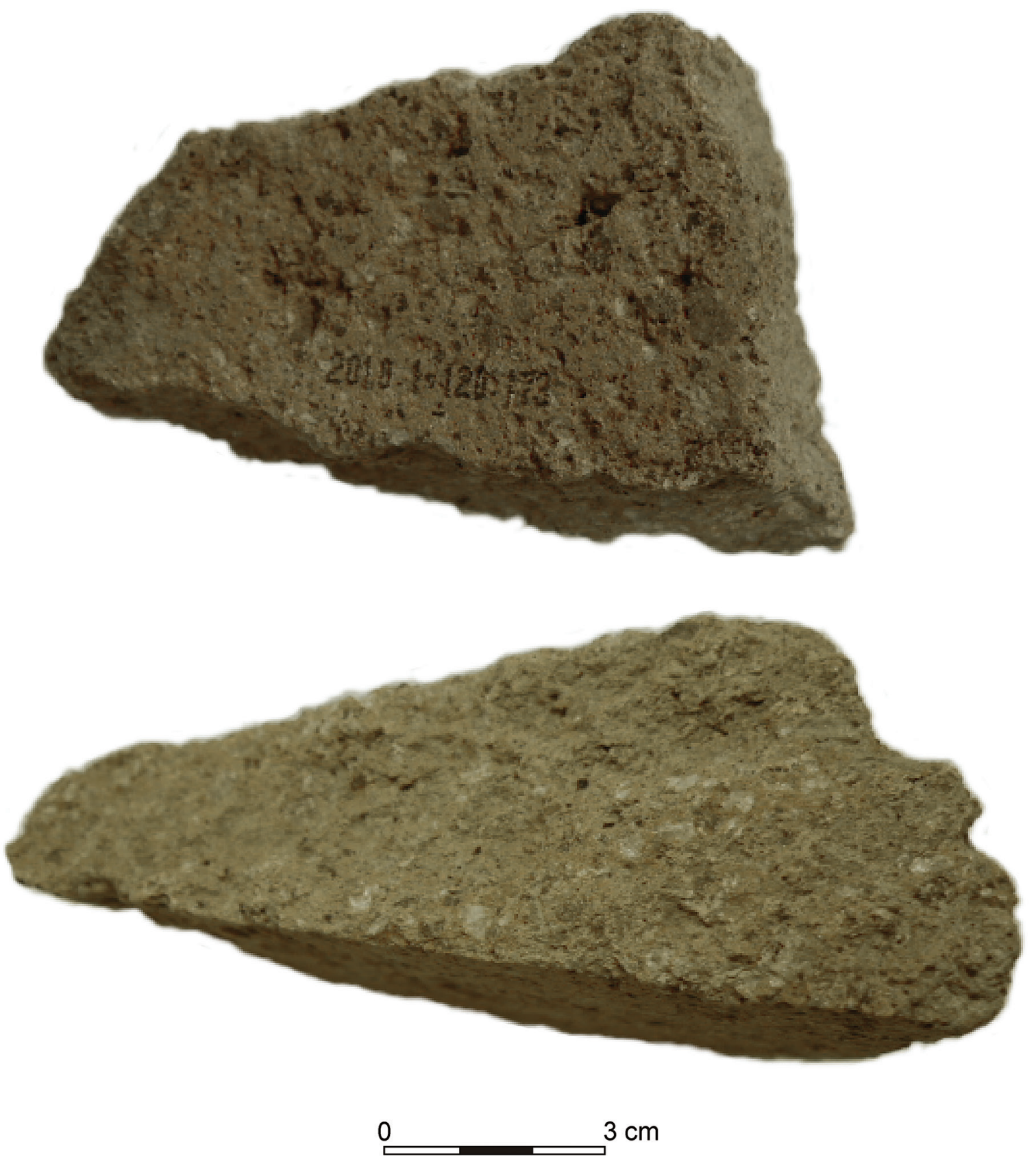

Fig. 29. Polgár-Piócási-dủlő. Fragment of quernstone (early phase) 

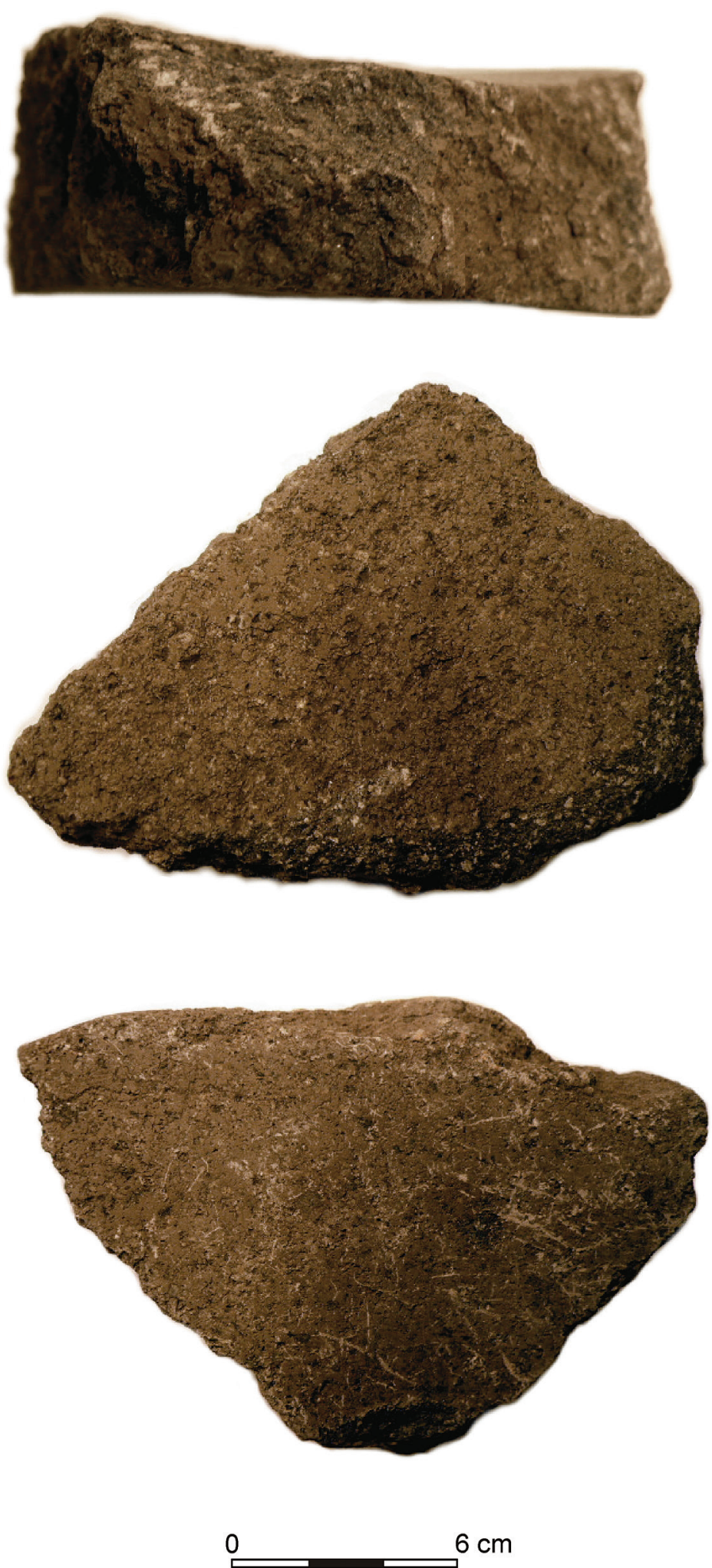

Fig. 30. Polgár-Piócási-dűlő. Fragment of quernstone (early phase) 

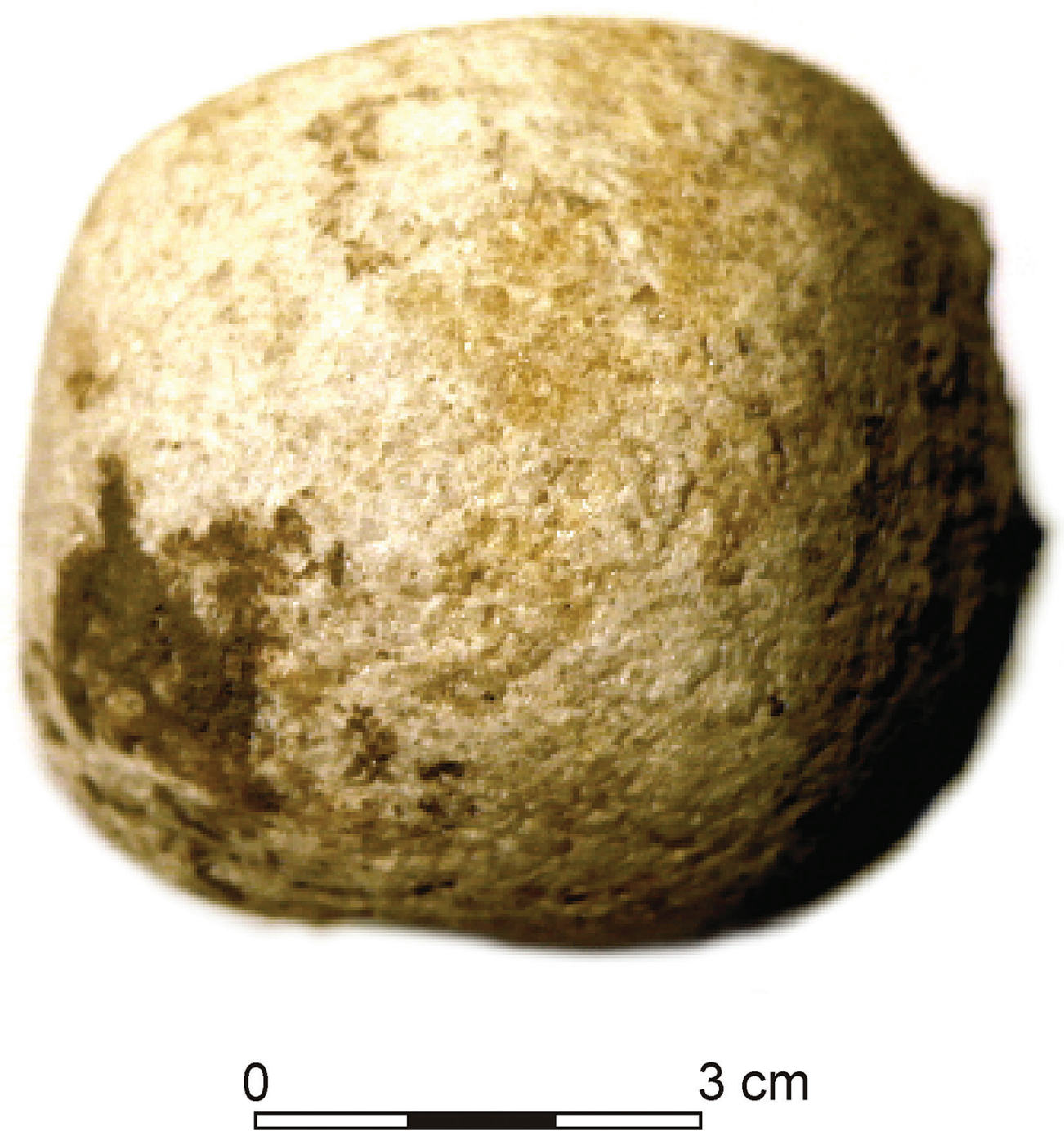

Fig. 31. Polgár-Piócási-dűlő. Grinder/hammerstone (early phase)

intensively used, the sides were worked by pecking, rounded corners, the horizontal cross-section is, too, asymmetrical (length $-59 \mathrm{~cm}$, width $-24 \mathrm{~cm}$ and thickness $3.8-9.2 \mathrm{~cm}$ ) (Fig. 36);

- 17 fragments of lower grinding stones and two fragments of a lower or an upper grinding stone (Fig. 37); the fragments discovered in feature 49 belong - most probably - to the same lower grinding stone although they do not form a refit;

- a fragment of a lower grinding stone, bi-concave, the two surfaces were used in succession.

The upper (active) grinding stones (group b) corresponding to the lower grinding stones described above were elongated, "loaf-shaped":

- a complete upper (active) grinding stone, "loaf-shaped"; its ends extend onto the sides of the lower grinding stone (length $-30.8 \mathrm{~cm}$, width $-11.0 \mathrm{~cm}$, thickness: centre $-3.1 \mathrm{~cm}$, end $-5.5 \mathrm{~cm}$ ) (the small thickness suggests intensive utilization); the associated lower grinding stone must have been about 19 cm broad (Fig. 38);

- a specimen that could have been a half-product of an upper (active) grinding stone (Fig. 39); 

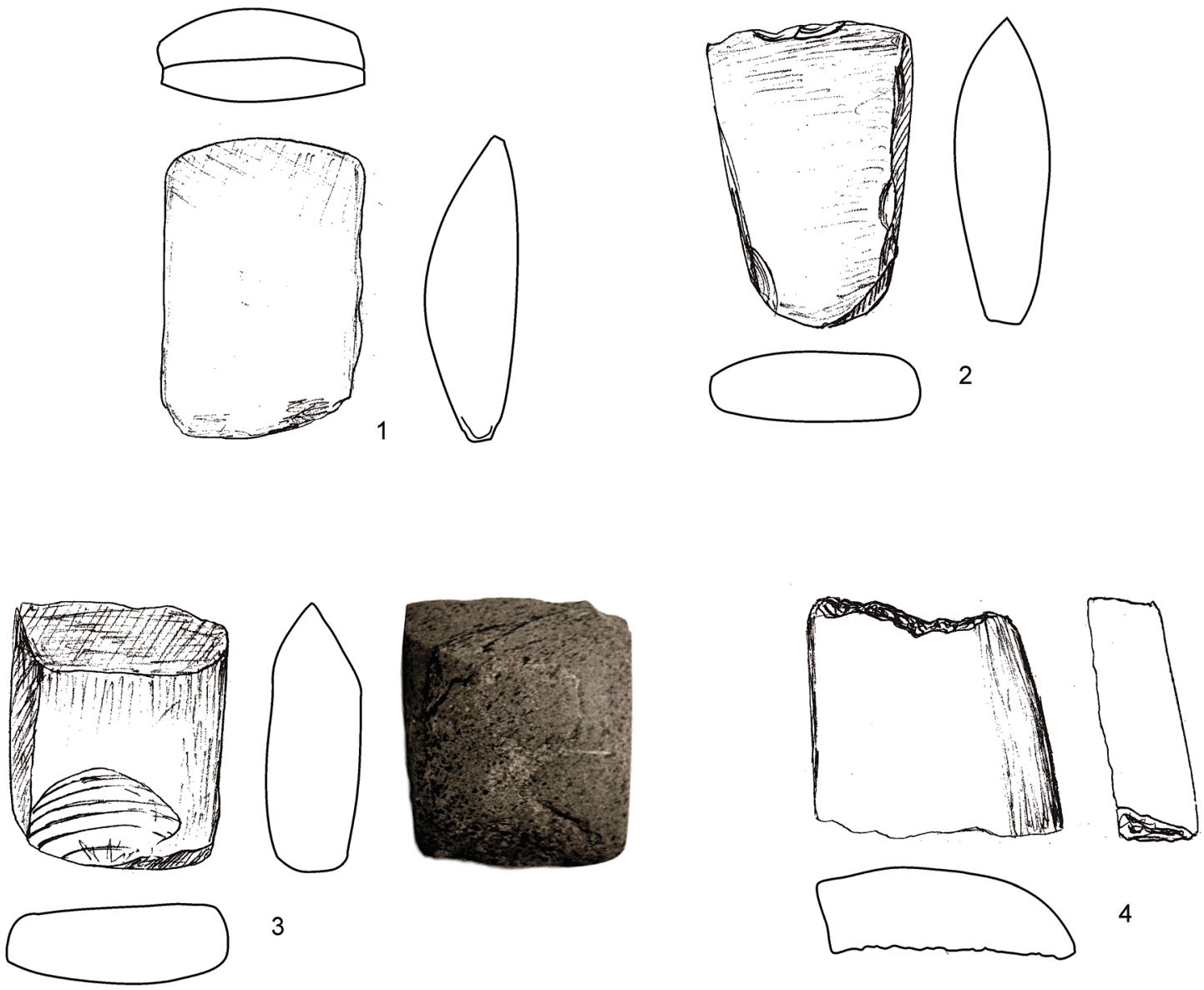

3

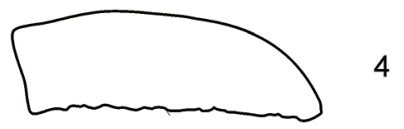

0 $3 \mathrm{~cm}$
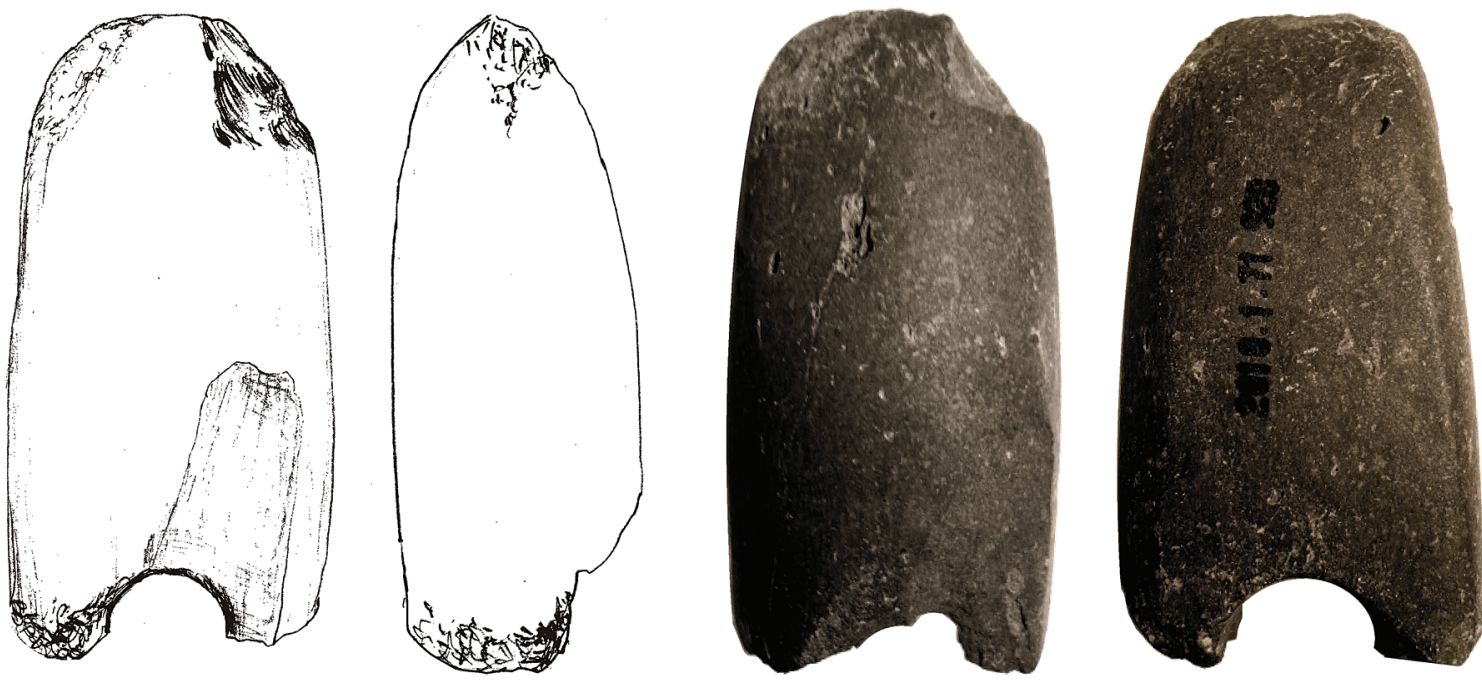

5

Fig. 32. 1: Polgár-Piócási-dủlö. polished axe from the early phase, 2-4: polished axes, 5: perforated axe from a late phase feature 


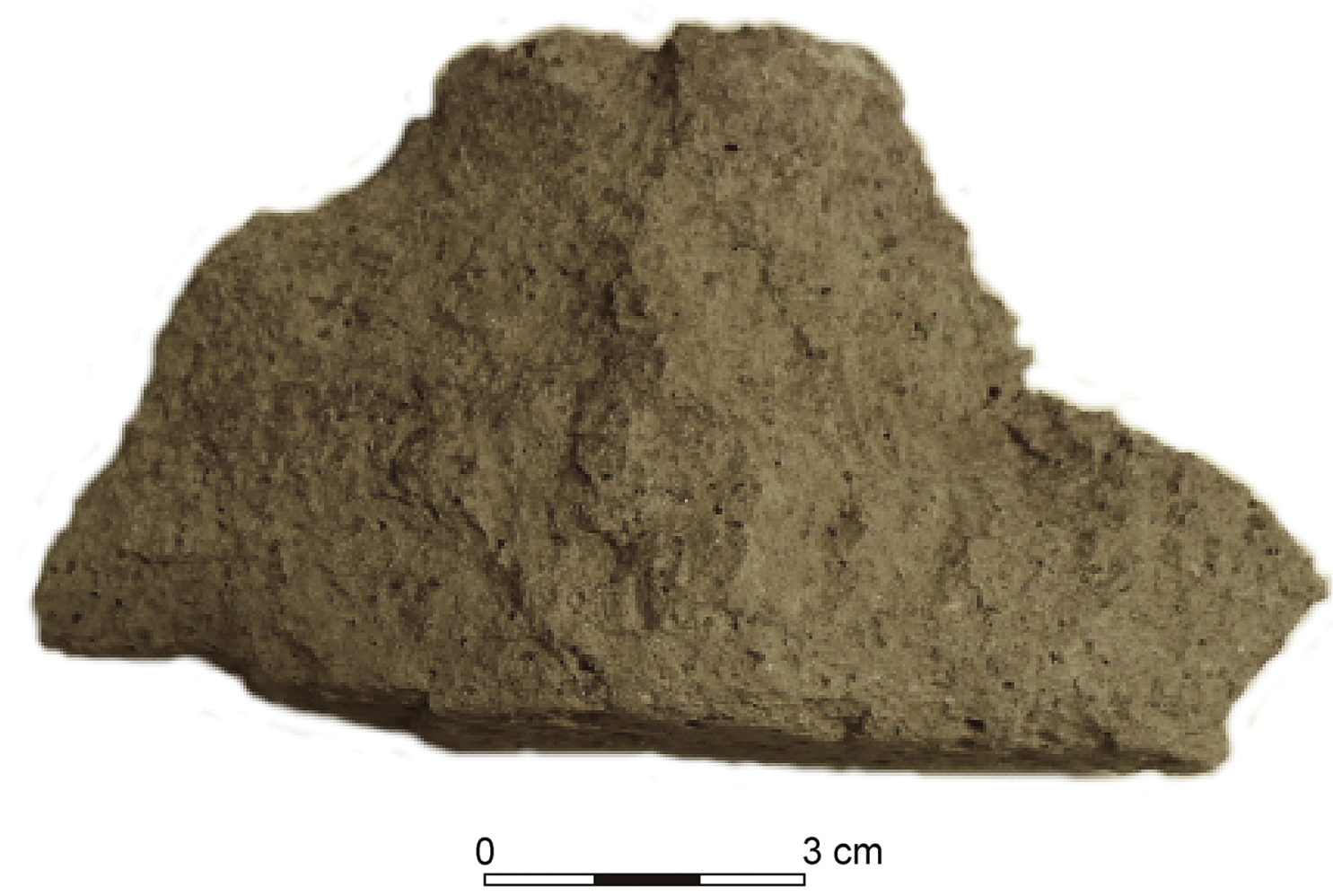

Fig. 33. Polgár-Piócási-dűlő. Flake struck from groundstone (early phase)

- 13 fragments of upper grinding stones that were made from the same raw materials as the corresponding lower grinding stones (width - from 8.0 to $16.0 \mathrm{~cm}$, thickness, depending on the degree of wear, from 2.5 to $6.6 \mathrm{~cm}$; Fig. 40);

- two fragments of lower or upper grinding stones.

Three fragments of thin plaquettes were made from fine-grained sandstone with mica, polished on one or on two surfaces. The polished zones are shallow depressions, oval or round (Fig. 41). These are not typical grinding stones, and in all likelihood their function was not grinding grain. One fragment shows remains of carbonate crust with phytoliths (Fig. 42).

Grinders and hammerstones-grinders (group c):

Seven specimens have been recovered. Two grinders show traces of crushing mineral dyes (Figs 43-44). A quartz pebble was broken when used as a hammerstone.

Polished stone implements:

- a small axe (length $-4.0 \mathrm{~cm}$, width $-2.8 \mathrm{~cm}$ ), trapezoidal in shape; it is rectangular in horizontal crosssection, with rounded corners, the cutting edge is weakly convex, the profile is asymmetrical; the back is blunt; the axe was made from black, homogeneous metamorphic rock, with a slightly greenish hue (Fig. 32.2);

- a fragment of an axe, flat-convex, fractured longitudinally and transversally, made from metamorphic black shale (Fig. 32.3);

- a short axe (length $-3.5 \mathrm{~cm}$, width $-3.2 \mathrm{~cm}$ ), probably modified (shortened when the cutting edge was rejuvenated), the cutting edge is asymmetrical; a sub-rectangular cross-section, the back is blunt; it was made from metamorphic, black shale (Fig. 32.4); 

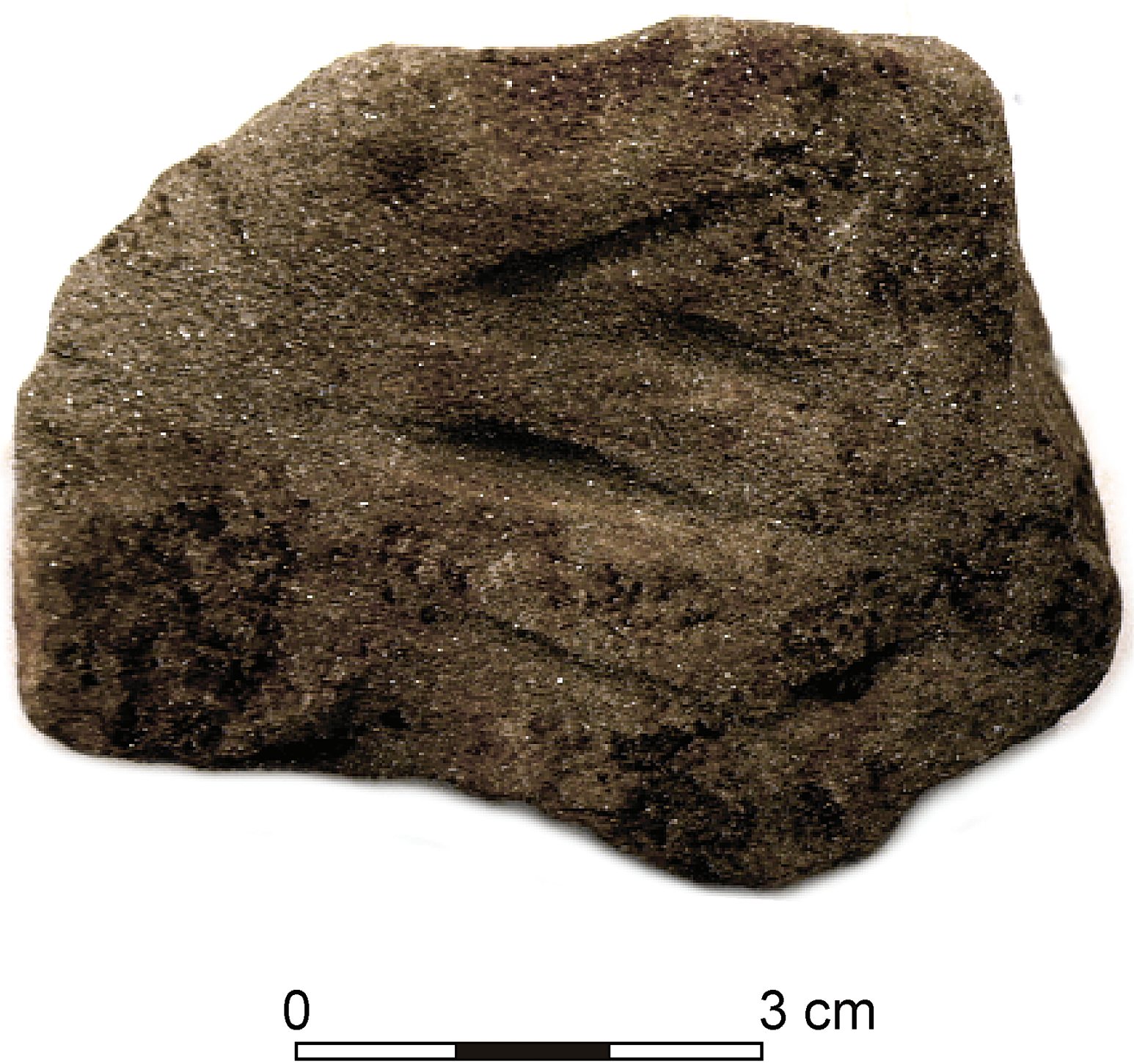

Fig. 34. Polgár-Piócási-dủlő. Fragment of groundstone with striations (late phase)

- moreover, the back of an elongated, perforated axe was recovered; it was broken at the perforation; the cross-section is almost round, the back is subdiscoidal; the specimen was made from volcanic rock (Fig. 32.5).

\subsection{Scatter-pattern of lithic artefacts}

The majority of lithics were recovered in the features of the early phase (Tables 4 and 5). The inventory of feature 132 was most abundant, with 140 chipped stones and 29 ground stones. The inventory consisted, besides, of a large number of other artefacts (incised sherds, miniature vessels etc.), archaezoological relics (fish, tortoise bones etc.) and daub. The feature consists of a long pit, probably located along the wall of the dwelling (pit 132, stratum 203) and a well (132, stratum 233). The long pit yielded all the cores (11), an obsidian concretion, and debitage products, which suggests that lithic production concentrated near this feature. Moreover, 28 ground stone implements were also recovered in the long pit. The specimens were strongly fragmented, probably intentionally. 

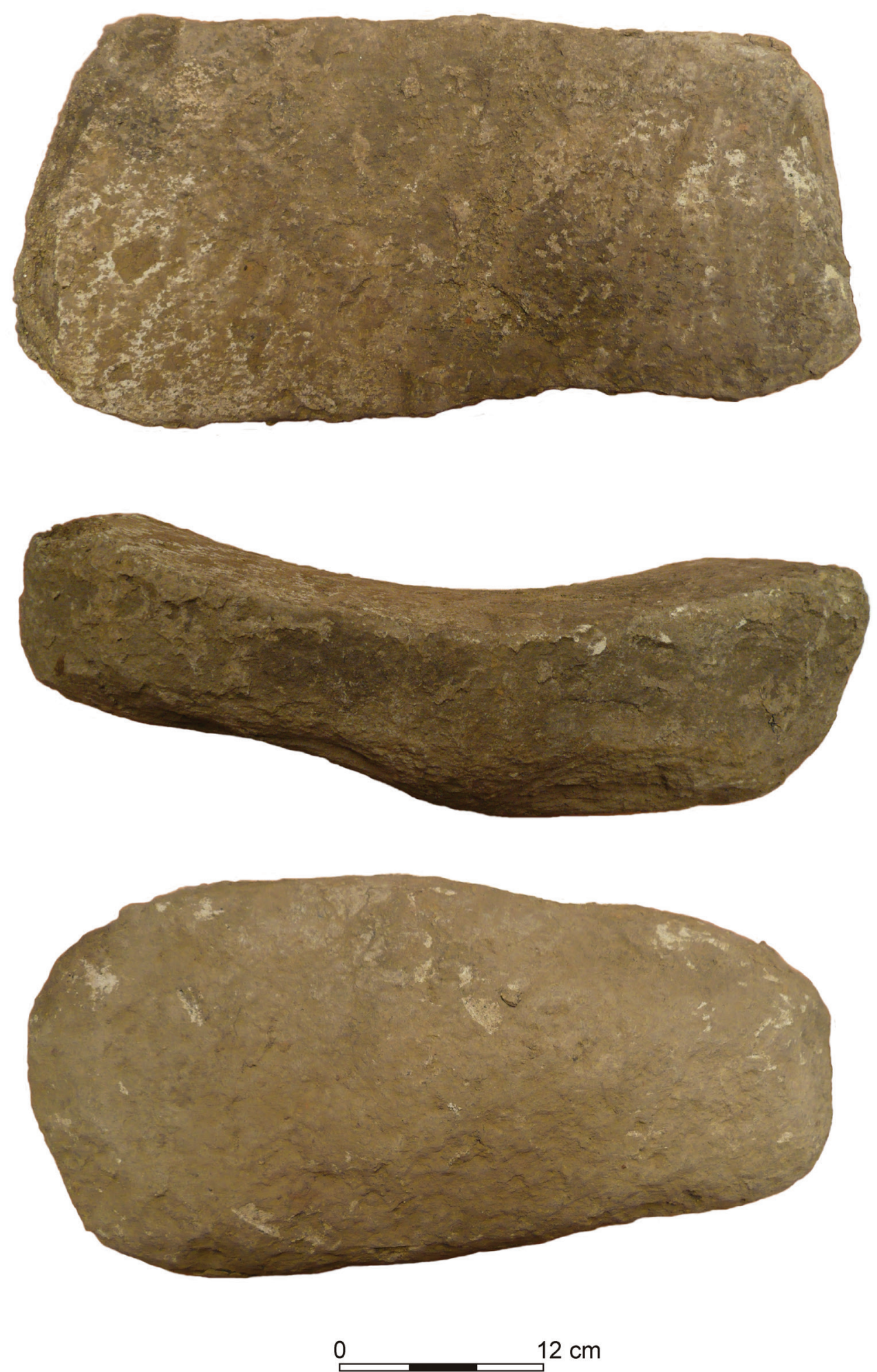

Fig. 35. Polgár-Piócási-dủlő. Lower grinding stone (late phase) 
Table 4. Polgár-Piócási-dülő. Major technological categories in features dated to the early phase

\begin{tabular}{|l|c|c|c|c|c|c|c|c|}
\hline \multicolumn{1}{|c|}{ Features } & Cores & Flakes & Blades & $\begin{array}{c}\text { Splintered } \\
\text { pieces }\end{array}$ & Chips & Tools & Others & Total \\
\hline 132 & $11+1^{*}$ & 51 & 42 & 2 & 8 & 24 & 1 \\
\hline 141 & & 2 & & & 1 & 1 & 8 & 1 \\
\hline 165 & 4 & 24 & 16 & & & 54 & 1 \\
\hline 180 & & 1 & 2 & & 1 & 1 & 2 & 1 \\
\hline 182 & 1 & 80 & 58 & 3 & 11 & 35 & 8 \\
\hline
\end{tabular}

Table 5. Tool groups in features dated to the early phase

\begin{tabular}{|c|c|c|c|c|c|c|c|c|c|}
\hline Feature & End-scraper & Burin & Perforator & $\begin{array}{c}\text { Retouched } \\
\text { flake }\end{array}$ & Truncation & $\begin{array}{c}\text { Denticulated- } \\
\text { notched }\end{array}$ & $\begin{array}{c}\text { Retouched } \\
\text { blade }\end{array}$ & $\begin{array}{c}\text { Side- } \\
\text { scraper }\end{array}$ & $\begin{array}{l}\text { Sicle } \\
\text { insert }\end{array}$ \\
\hline 132 & 2 & & & 8 & 3 & 3 & 7 & 1 & \\
\hline 141 & & & & & & & 1 & & \\
\hline 165 & 2 & & & 2 & & 1 & 2 & 1 & \\
\hline 182 & & & & 1 & & & & & 1 \\
\hline Total & 4 & & & 11 & 3 & 4 & 10 & 2 & 1 \\
\hline
\end{tabular}

From the well (feature 132, stratum 233) 5 tools were recovered (a blade-flake, a blade with lateral retouch, an endscraper, a retouched flake, and a side-scraper), a fragment of fractured blade with a pseudo-burin scar (probably from pressure), and a spherical grinder-hammerstone from quartz (Fig. 31). Such an inventory structure indicated intentional deposition of tools exclusively (without the debitage) in the well, possibly of ceremonial significance.

The number of finds in the other early phase features, notably ground stones, was smaller. Feature 165 (partially explored) provided 54 chipped stone artefacts (cores -4 , flakes -24 , blades -16 , retouched tools -8 and others), 5 ground stones, a polished stone tool, and numerous ceramic items. In feature 141 lithics were even fewer ( 4 chipped stones), just as in feature 180 (one chipped stone), and 182 ( 8 chipped stones).

Among the late phase features the inventory of feature 87 was the most abundant. This feature was a clay extraction pit located by the wall of dwelling 92. Its inventory consisted of 25 chipped stone artefacts ( 3 cores, 8 flakes, 9 blades, 5 tools - a sickle insert, two retouched blades, an end-scraper and a burin), and 34 ground stones (including 11 fragments of upper grinding stones and only two lower grinding stones). Moreover, numerous ceramic objects were found (among them a vessel with a dancing scene). The remaining (non-diagnostic) features contained several specimens each (pit 57 - 11 chipped stones including 2 flakes, 5 blades, 2 retouched tools; pit 59: a core and two tools; pit 75: a flake, a blade, 2 tools; pit 161: a core and two flakes).

The inventory structure of the various features of the two settlement episodes does not indicate a workshop function of these features. Possibly, a workshop may have been located near feature 132. The fact that most lithics were found within one exploration unit (stratum 233) documents their deposition in a single episode of filling the pit. Artefacts in the other features evidence a variety of standard domestic activities.

\subsection{The two settlement episodes at the site of Polgár-Piócási-dülö}

Despite overall similarities of the two settlement phases, detailed analysis has revealed fairly significant differences. It should be added that the number of artefacts in the second, later, phase is so small that the conclusions proposed may be fallacious.

Most importantly, the proportion of obsidian drops, which is replaced by limnoquartzites (Fig. 45). In the inventory structures in the second phase features a tendency is noticeable towards increase in the blade and tool component, which suggests that blank and tool production was transferred beyond the settlement (Fig. 46). The smaller size of cores and blades in the later phase features indicates that prepared and partially reduced cores were brought to the settlement. Flake dimensions, too, become smaller further confirming the above supposition. Changes 

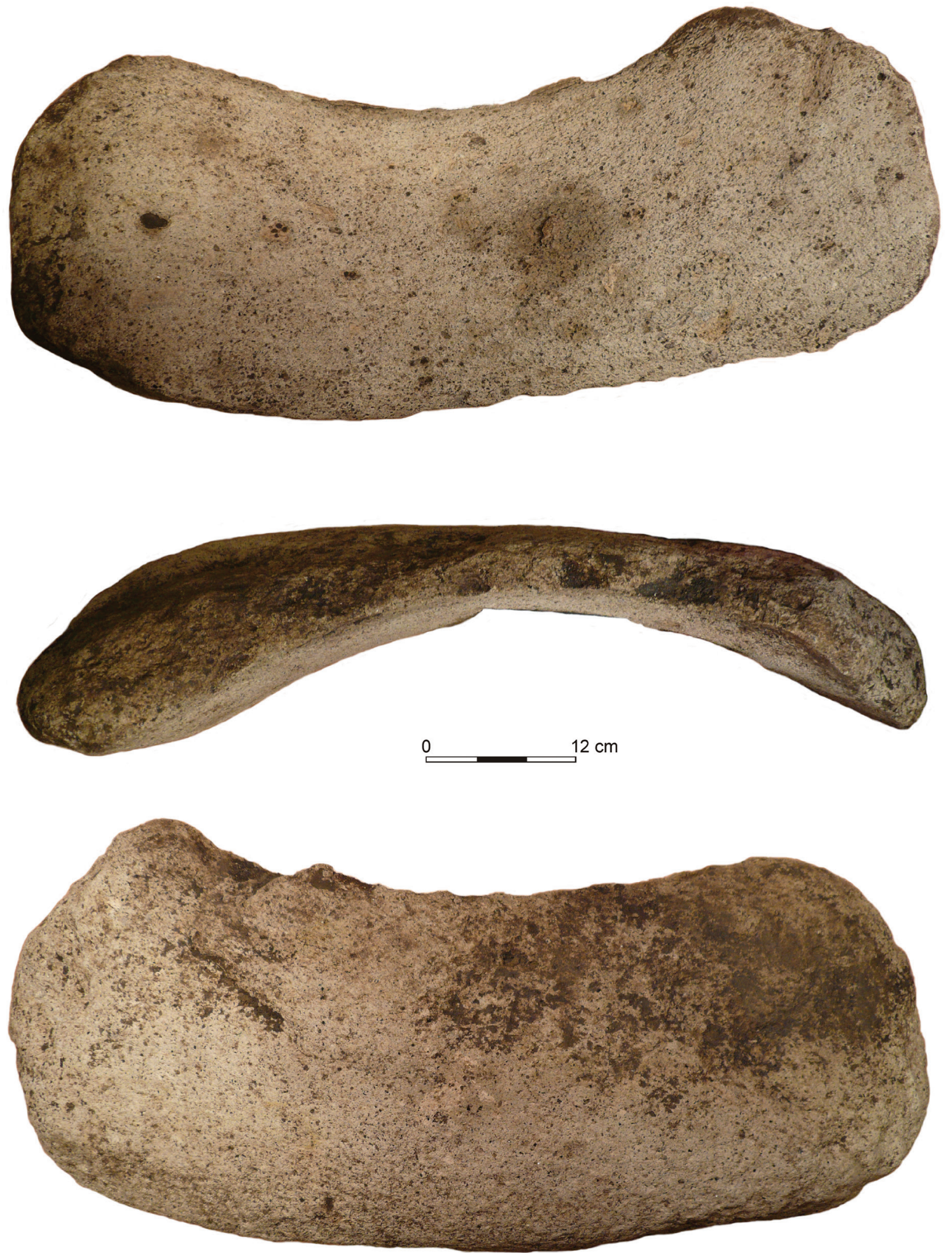

Fig. 36. Polgár-Piócási-dűlő. Lower grinding stone (late phase) 
in the mode of core reduction also took place: in the early phase cores with platforms rejuvenated by detaching a tablet are more numerous, whereas in the later phase features blanks with facetted platforms are more frequent; these changes may have been caused by a more thrifty economy of exploitation of obsidian supplied to the settlement.

In the features of the early phase at the site harvesting tools are not numerous and grinding stones are few. This could have been the result of a smaller role of cereals cultivation in the early phase; however, the small number of sickle inserts can also be accounted for by the fact that on obsidian artefacts functional use-wears of sickle inserts are difficult to identify. The assemblage of identifiable grinding stones in the early phase is smaller ( 7 specimens) than in the younger features ( 37 specimens), which could be related to a minor role of cereals cultivation in the older phase, or could be the result of utilizing ground stone implements in subsequent settlement episodes.
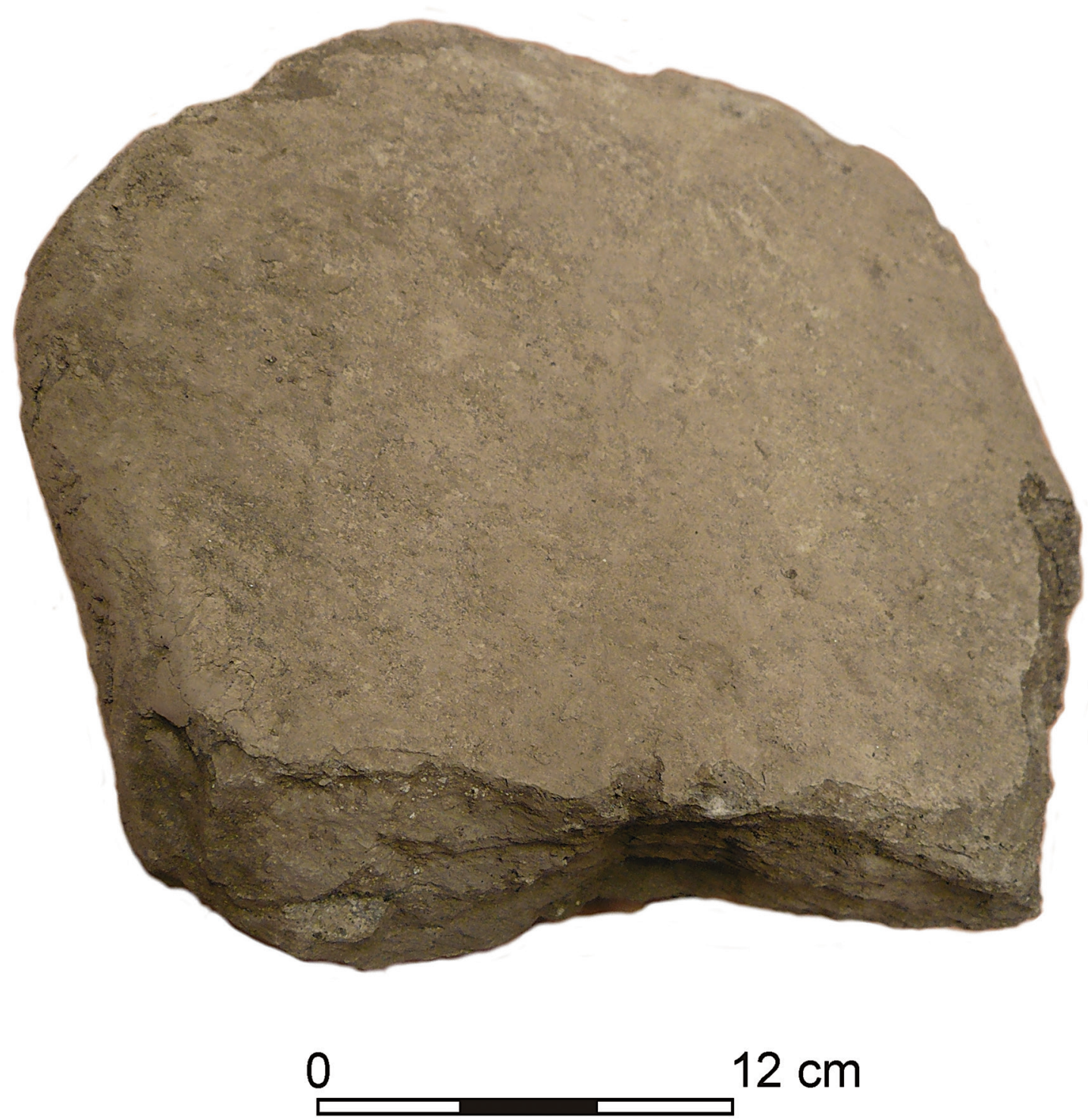

Fig. 37. Polgár-Piócási-dülő. Fragment of lower grinding stone (late phase) 

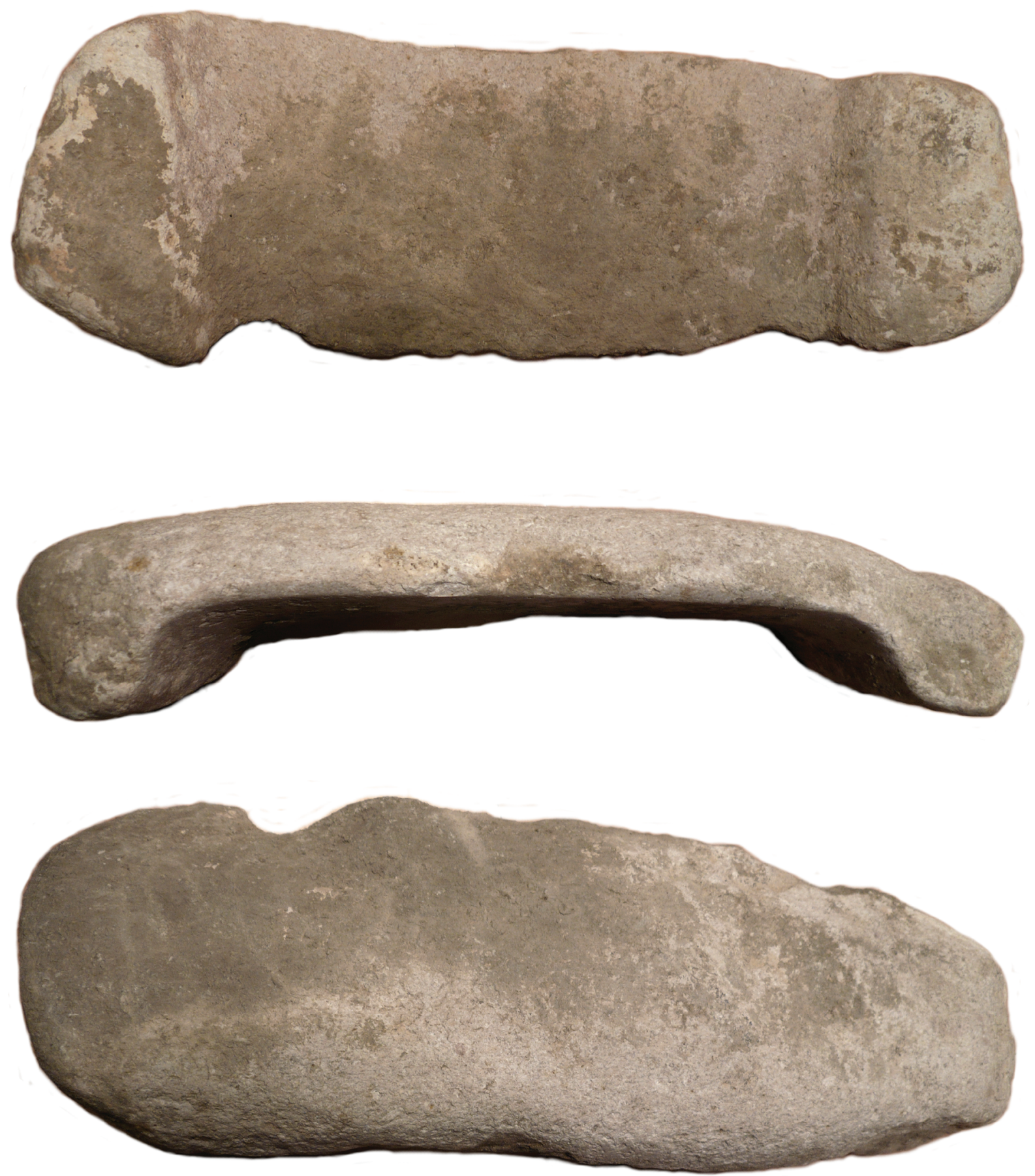

0 $6 \mathrm{~cm}$

Fig. 38. Polgár-Piócási-dủlö. Upper grinding stone (late phase) 

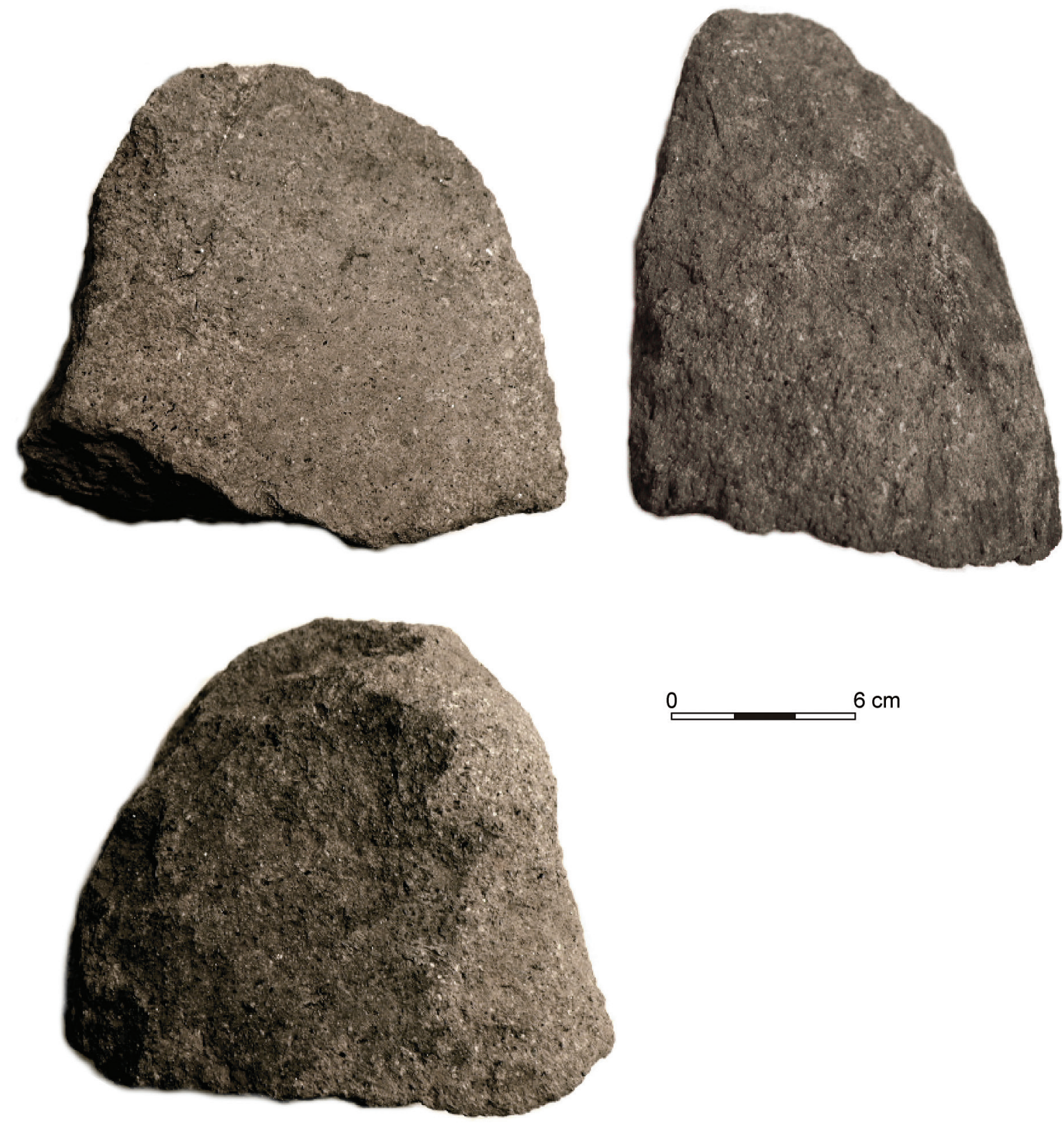

Fig. 39. Polgár-Piócási-dủlő. Half-product of upper grinding stone (late phase) 

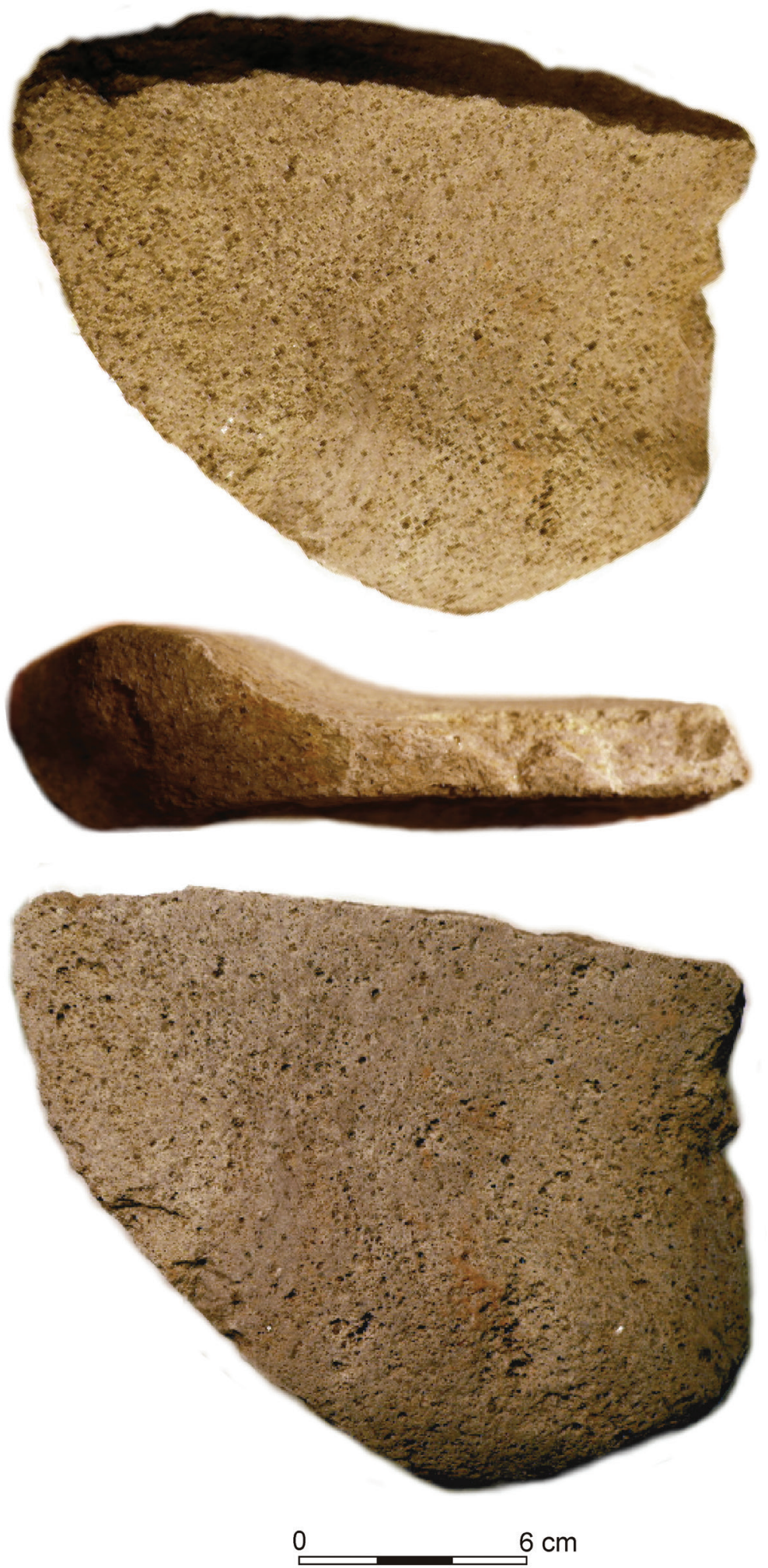

Fig. 40. Polgár-Piócási-dűlő. Fragment of upper grinding stone (late phase) 


\subsection{The position of the industry from Polgár-Piócási-dülö in the variability}

of industries of the Eastern Linear Pottery Culture

The main body of lithics from the site of Polgár-Piócási-dülö can be ascribed to the early phase of the Eastern Linear Pottery Culture (Szatmár II Phase). The site is situated in the "Polgár island" where six sites of the Early Phase (I) have been identified, also 20 sites of phases II-III and 8 sites from phase IV. ${ }^{90}$ Most artefacts from the site of Polgár-Piócási-dülő represent the early phase of the Eastern Linear Pottery Culture. Polgár-Ferenci-hát, on the other hand, represents - with the exception of few artefacts belonging to the early phase - the late phase of the Eastern Linear Pottery Culture.

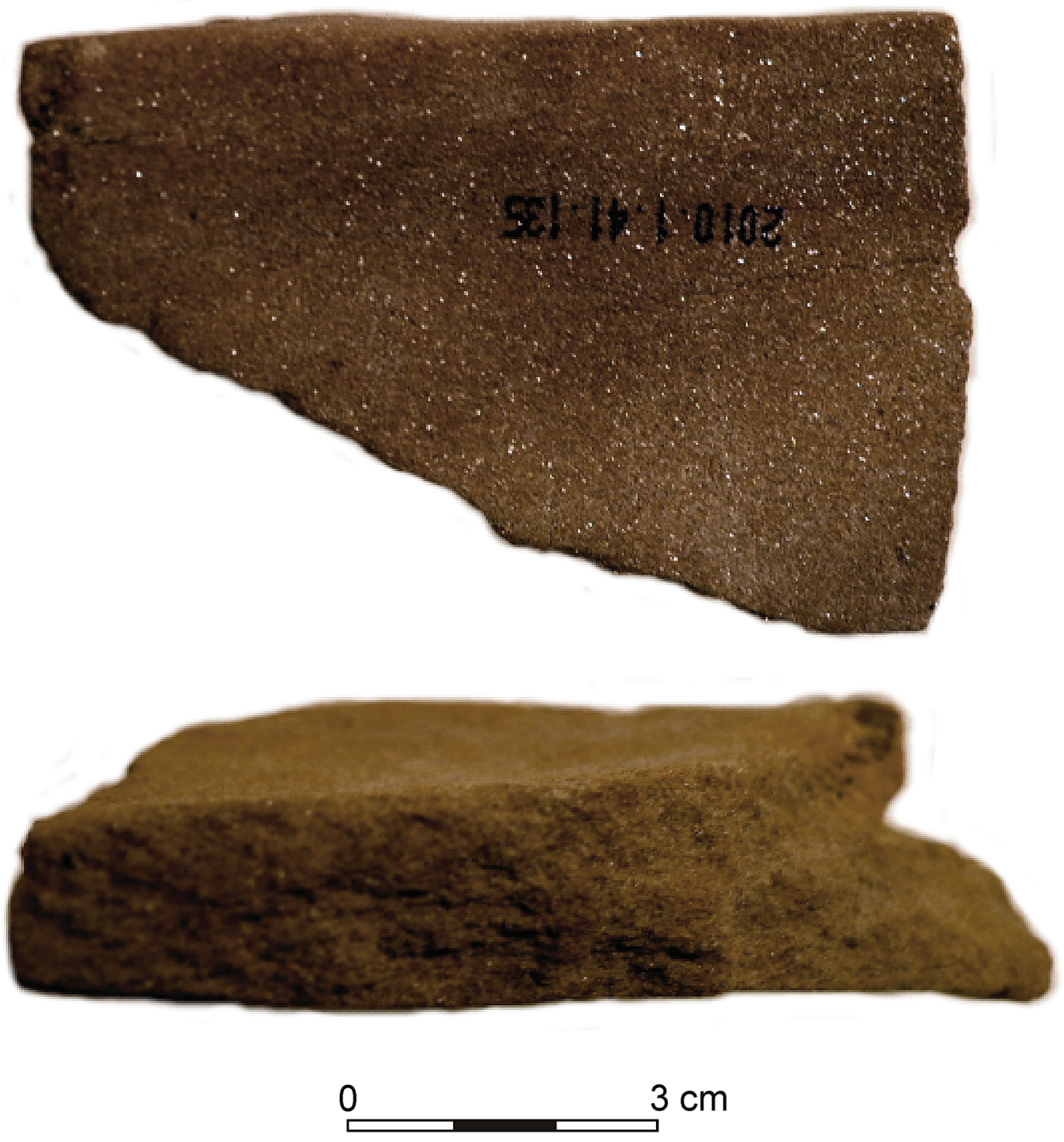

Fig. 41. Polgár-Piócási-dűlő. Polished stone plaquette (late phase)

${ }^{90}$ RACZKY-ANDERS 2009. 

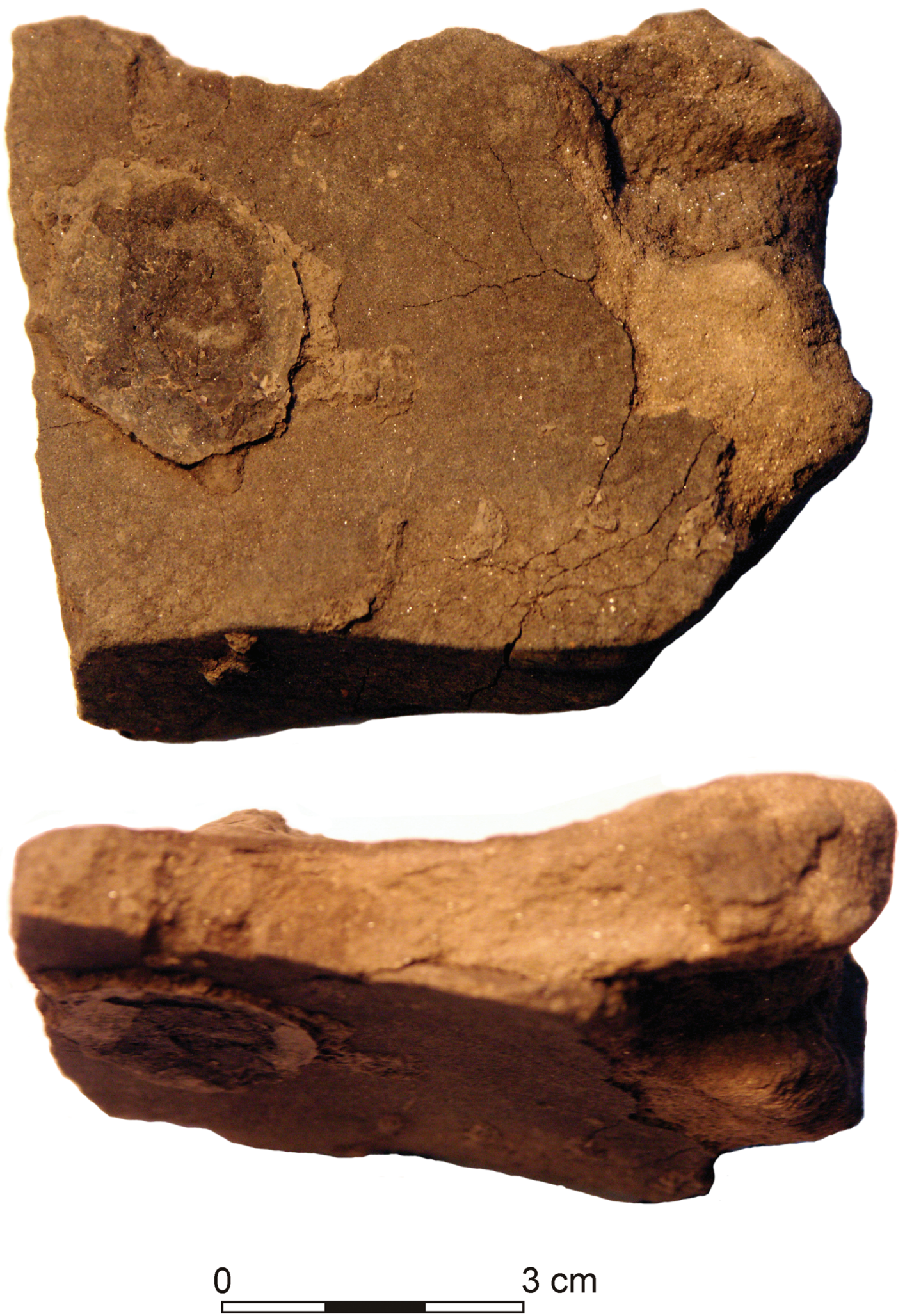

Fig. 42. Polgár-Piócási-dủlő. Polished stone plaquette (late phase) 

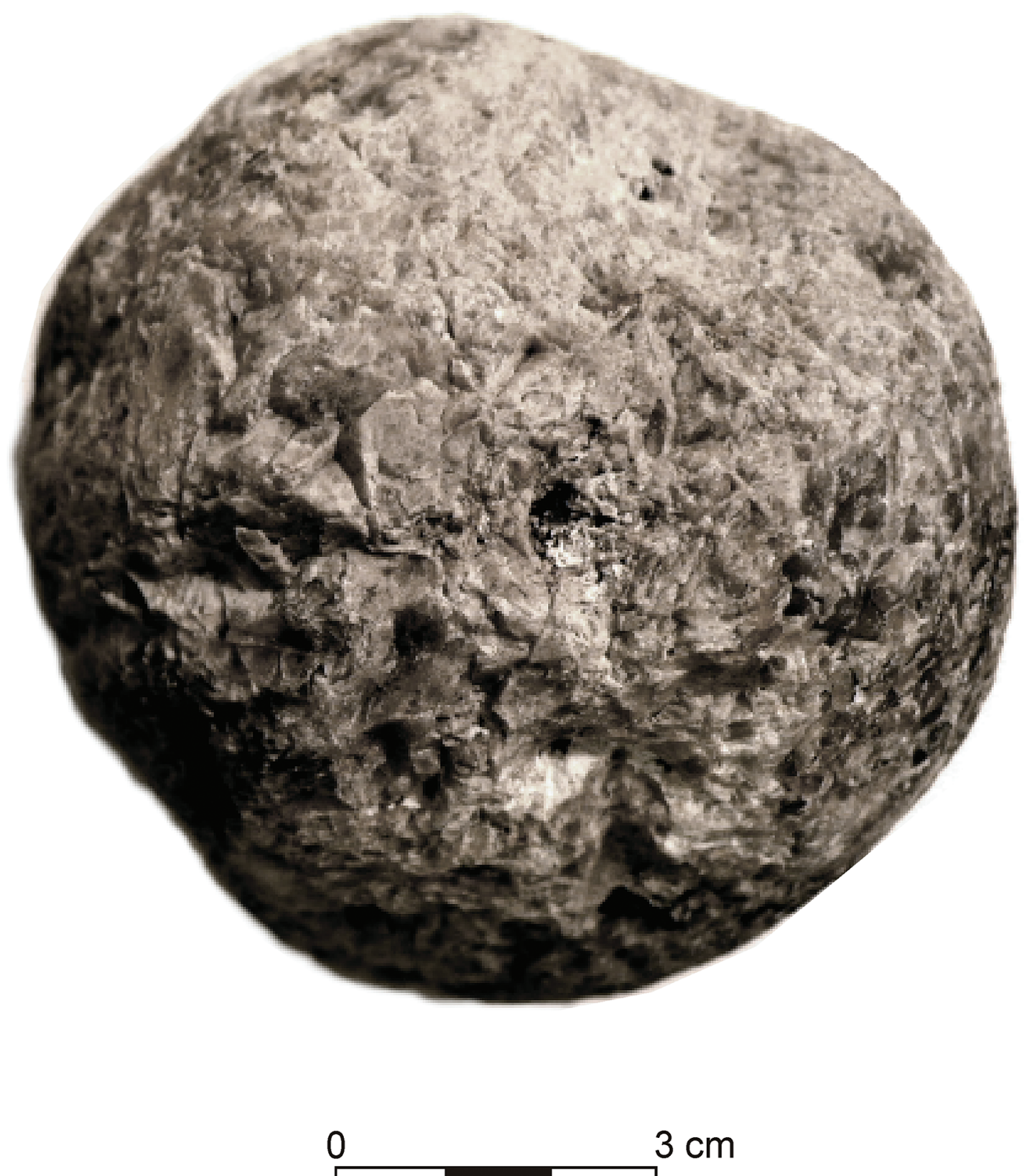

Fig. 43. Polgár-Piócási-dűlő. Grinder/hammerstone (late phase)

In the "Polgár island" only a few sites of the early phase of the Eastern Linear Pottery Culture were excavated (among others: Polgár-Piócási-dűlő, Polgár-Kenderföldek, Polgár-Ferenci-hát), but only one site i.e. Polgár-Piócásidülö yielded a larger series of lithic artefacts. The excavated early phase sites are relatively small, with one or two dwellings. From this phase figurines related to the Méhtelek group are recorded as well as decoration motifs of ceramics that are derived from the Körös Culture tradition. ${ }^{91}$ For the site of Polgár-Ferenci-hát (lower layer) radiometric date of 5467-5344 cal BC has been obtained ${ }^{92}$ this date is close to the dates from Polgár-Piócási-dülő (Figs 5-6).

${ }^{91}$ RACZKY-ANDERS 2009.

92 RACZKY-ANDERS 2009, 43. 
Location of sites and their chronology are vital determinants of the variability of the Eastern Linear Pottery Culture. Most importantly, the links with preceding culture units and processes of adaptation to the various environments in the north-east part of the Carpathian Basin played a major role in the evolution of technological traditions. These links gave rise to the mosaic of lithic industries of the Eastern Linear Pottery Culture.

As early as the Late Körös horizon two processes can be seen: the replacement of raw materials imported from the south ("Balkan flint") by local raw materials and obsidian from the Tokaj Mountains and the Zemplín
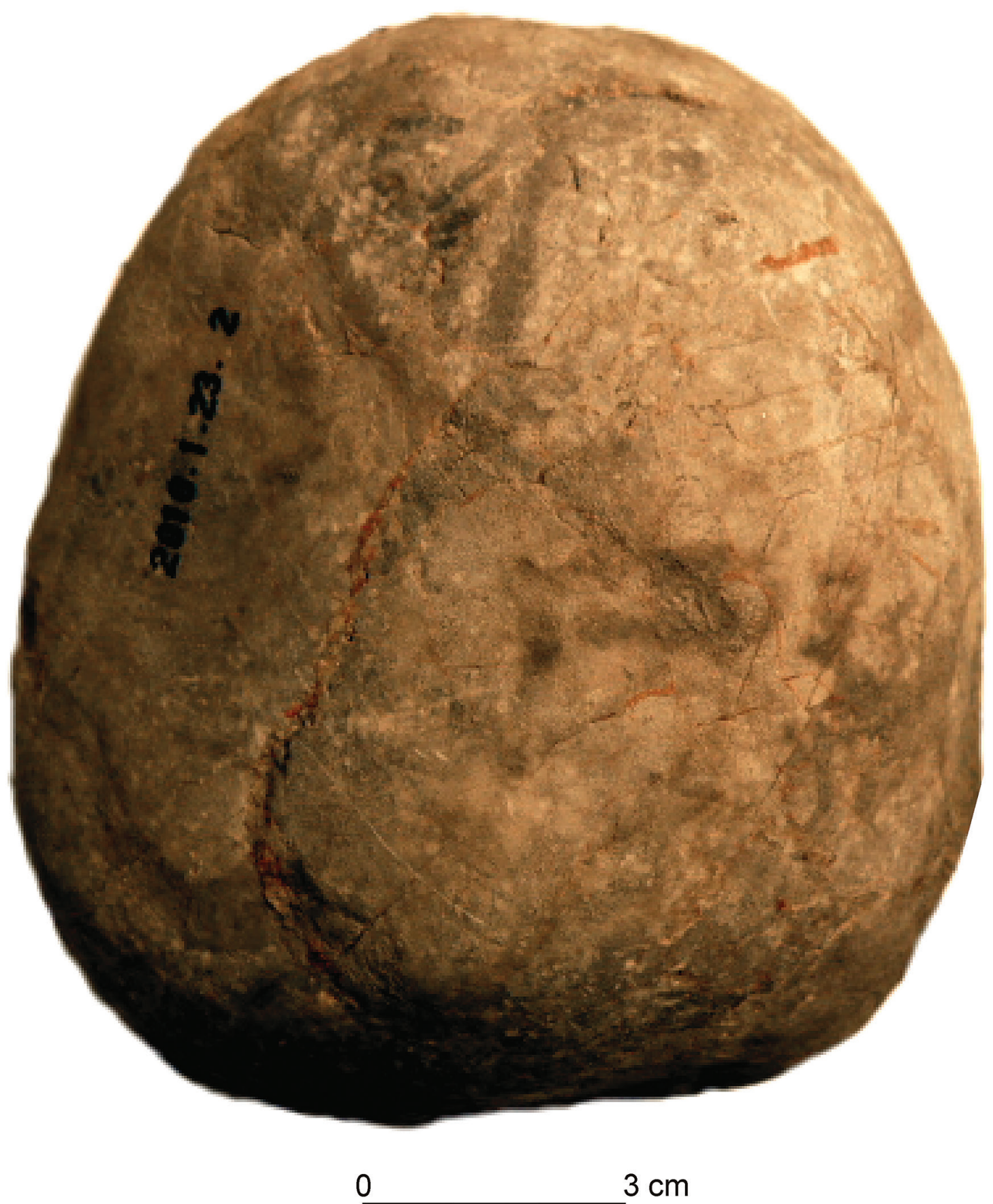

Fig. 44. Polgár-Piócási-dűlő. Grinder/hammerstone (late phase) 


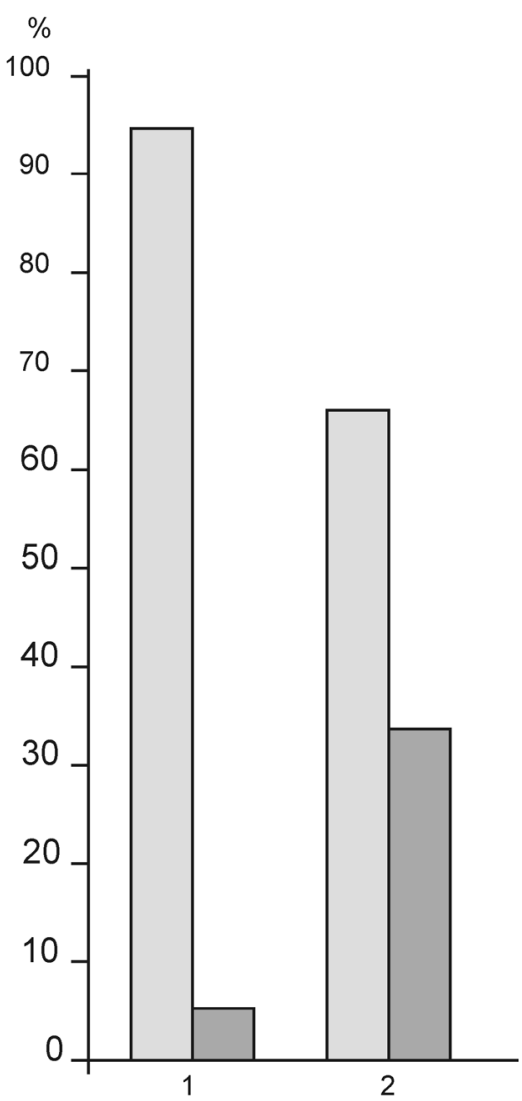

Fig. 45. Polgár-Piócási-dűlő. Raw materials in early Phase features (1) and in late phase features (2). Left: obsidian; right: limnoquarzites

Plateau, and - secondly - the shifting of core reduction from specialized workshops near deposits to settlements. In comparison with the youngest Körös Culture sites at the northern peripheries of its domain ${ }^{93}$ the earliest sites of the Eastern Linear Pottery Culture show a sharp drop in the proportion of tools and hunting weapons, among others of microliths with impact fractures - although microliths could have been used as inserts for tools with other functions. In the final phase of the Körös Culture the techniques of reduction of obsidian blade cores change. Changes become most conspicuous in the earliest phase of the Eastern Linear Pottery Culture (e.g. in the early phase at PolgárPiócási-dülö) and consist in, commonly applied, core platform rejuvenation by detaching tablets.

While the sites of the Eastern Linear Pottery Culture that follow the technological tradition of the Körös Culture concentrate to the east of the Upper Tisza and, to its tributaries, the Torysa and the Ondava basins ("Eastern group"). The evolution of the Eastern Linear Pottery Culture to the west of the Tisza, together with the Hornád and the Košice basins was different. To the "Western" group belong sites such as Košice-Červený rak (the Proto-Linear Phase) $)^{94}$ and Čečejovce (from the early phase). ${ }^{95}$

At the boundary of these two groups, with no clear indications of either group, are the sites in the "Polgár island" such as Polgár-Piócási-dülő, analysed here, and Polgár 31 (assemblage of the early [I] phase of the Eastern Linear Pottery Culture).

The "Western" province of the Eastern Linear Pottery Culture is distinguished by, first of all, the smaller role of blade technology and a greater component of flakes for blanks. Thus, the proportion of blades with lateral

\footnotetext{
${ }^{93}$ Ecsegfalva - MATEICIUCOvÁ 2007; Ibrány - DomboróCZKI-RACZKY 2010, Tiszaszőlős-Domaháza-puszta - DoMBorócZKI et al. 2010.
}

\footnotetext{
${ }^{94}$ KAMINSKÁ et al. 2008.

${ }^{95}$ KoZŁOWSKI 1989; KoZŁOWSKI 2001.
} 


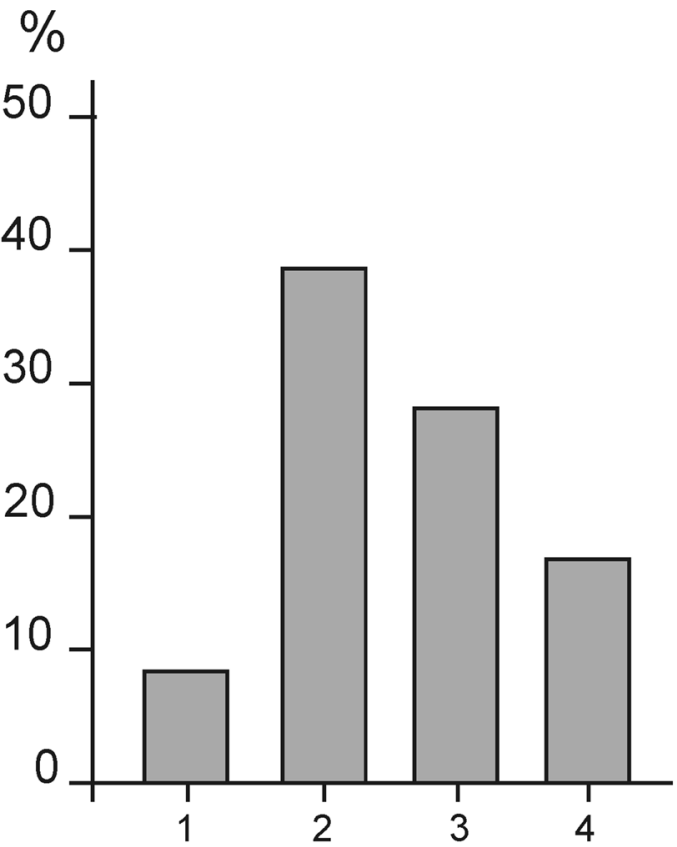

a

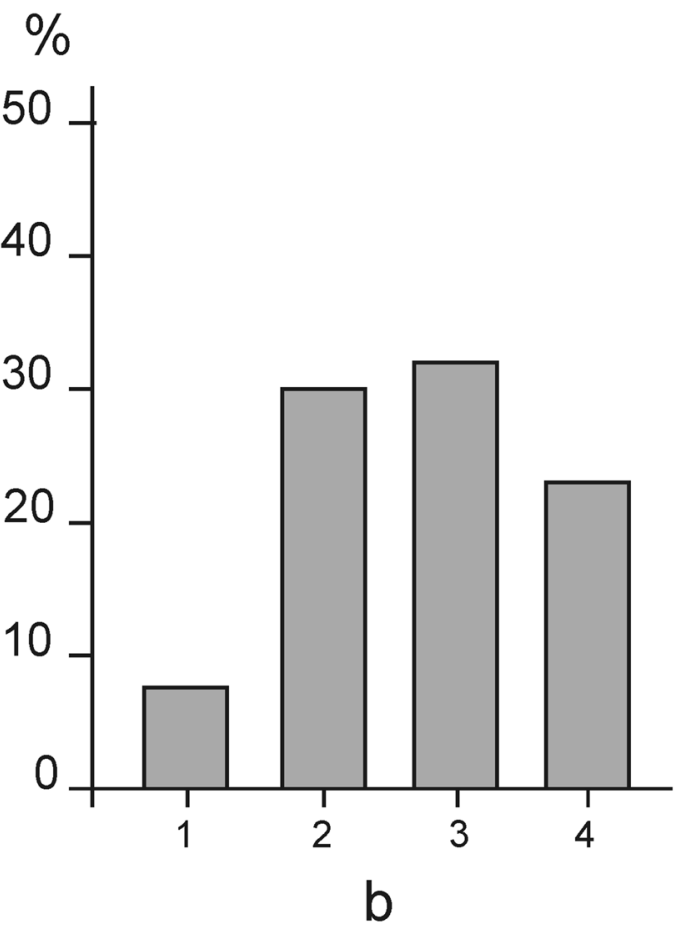

Fig. 46. Polgár-Piócási-dủlő. Main technological groups in early phase features. (a) and in late phase features (b). 1: cores; 2 : flakes; 3 : blades; 4 : tools

retouch (often partial, irregular) is less than $20 \%$, while that of retouched flakes increases up to even $29.3 \%$ at Čečejovce. Other tool groups are end-scrapers (even more than 20\%) and truncations (more than 10\%).The raw materials structure in the "Western" province mostly in the Košice Basin, is based on limnoquartzites (KošiceČervený rak: limnoquartzite $-59.4 \%$ and obsidian $-29.3 \%$; Čečejovce: limnoquartzite $-62.9 \%$, obsidian $32.8 \%{ }^{96}$ ), although at some Eastern Linear Pottery Culture sites to the south of the Bükk Mountains the proportion of obsidian is fairly high. ${ }^{97}$ The raw materials composition of the early inventories from the "Polgár island", which based mainly on obsidian (Polgár-Piócási-dülő: early phase -94.6\%) is similar to the raw materials structure at those sites.

The "Eastern" province of the Eastern Linear Pottery Culture, on the other hand, consists first of all of sites in the Eastern Slovakian Lowland (Slavkovce, Moravany and Zemplinske Kopčany - dated at 5600-5400 cal BC; 98 also Zbudza, Zalužice older phase). ${ }^{99}$ At these sites the Körös Culture technological tradition is manifested primarily in the high frequency of blades with marginal retouch. The frequency of end-scrapers at some sites (except Moravany) is fairly high (12.3\% - Zemplinske Kopčany, 20.8\% - Zbudza); the index of microlithic inserts shows major oscillations (up to more than $10 \%$ at Slavkovce to about $1.7 \%$ - Zalužice older phase). Thus, in the "Eastern" group, too, technological variability can be seen, which stimulated the emergence of both the Eastern Painted Pottery Culture ${ }^{100}$ and the Bükk Culture.

In respect of raw materials the "Eastern" group is more homogeneous, dominated by obsidian. Obsidian deposits are situated in the Zemplín Plateau bordering the Eastern Slovakian Lowland from the south, and linked to it via communication routes of the Ondava and the Torysa valleys. Obsidian reached the sites as unworked nodules which is documented, for example, at Slavkovce by a depot of obsidian concretions. ${ }^{101}$ At some sites of the "Eastern" group, Transcarpathian raw materials appear such as Cretaceous flint from the Dniester Basin or "chocolate" flint from the Middle Vistula Basin.

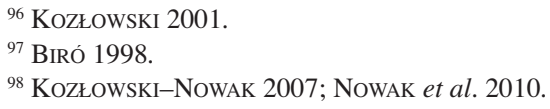

${ }^{98}$ KoZŁOWSKI-NOWAK 2007; NowAK et al. 2010.

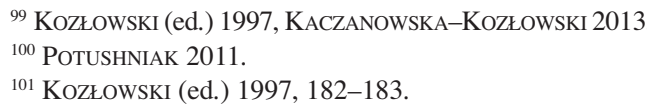


The further evolution of the "Eastern" group is associated with the Bükk Culture whose lithic industries continue the Körös Culture tradition - on the one hand, and, show some local variability independently of the uniform ceramic stylistics - on the other hand.

The neovolcanic territories surrounding the Hungarian Plain were, too, a source of raw materials for the ground stone industry. Possibly, the raw material used for the manufacture of grinding stones at Polgár-Piócási-dülö came from these areas. The lower grinding stones at Polgár-Piócási-dülő are elongated, while upper grinding stones are loaf-shaped and extend onto the sides of the lower grinding stones. A similar type of grinding stones was also used at a younger site of Polgár-Ferenci-hát. Bowl-shaped grinding stones where food staffs were crushed by means of spherical grinders and circular movements were much less common. This type was used at the sites belonging to an earlier chronological horizon (Endrőd 119, Szarvas 23, Szarvas 8$)^{102}$ although elongated grinding stones could also be used (Méhtelek). ${ }^{103}$

In the territory of the "Polgár island" diachronic changes are also recorded between assemblages of the Early Linear Phase (Polgár-Piócási-dülö) and the Later Phase (contemporaneous with the Bükk Culture - most materials from Polgár-Ferenci-hát, dated at the time interval of 5293-5068 years cal BC). The proportion of obsidian dropped, but also organization of production changed: at Polgár-Piócási-dủlő core reduction was carried out on-site - although preliminary stages of production, could have been carried out elsewhere, in the unexplored zones of the site. At Polgár-Ferenci-hát the early stages of preparation and reduction (mainly of obsidian) took place outside the settlement, possibly near deposits. It is likely that at Polgár-Ferenci-hát obsidian was not only used as raw material for tool production, but could have had a ceremonial significance as a prestigous piece of goods. This is documented by the deposition of special, large and very regular obsidian cores in graves.

Some differences between the sites of phase I and phase IV in the "Polgár island" resulted from the different structure of non-agricultural occupations of inhabitants.

\section{CONCLUSIONS}

Investigations at the site of Polgár-Piócási-dülö have revealed the presence of two settlement phases. The first corresponds to the Eastern Linear Pottery Culture I and is represented by a number of features concentrating in one sector of the explored area. In the second, younger phase, corresponding to Eastern Linear Pottery Culture IV, the settlement shifted to another sector where it is represented by well-preserved post houses. This settlement phase shows links with the central settlement in this part of the "Polgár island", namely the site of Polgár-Ferencihát where, in turn, the traces of the early phase are scant.

The first characteristic feature of the Piócási-dúlő settlement was a striking intensity of craft actvities. The immense number of pottery fragments recovered in refuse pits reflects diverse domestic craft activities and a culinary culture that distinguish this settlement from other areas.

In both settlement phases lithic production activities are manifested both by the local on-site lithic production and - most importantly - by the presence of imported, mainly mesolocal, raw materials that point to contacts with deposit areas, or off-site preliminary working of obsidian and limnoquartzites. The kit of harvesting tools and a large number of grinding stones - especially in the younger phase - for the preparation of plant food suggest a major role of plant cultivation. In comparison with Polgár-Ferenci-hát, on the other hand, woodworking was of minor importance: at Piócási-dủlő axes and perforated axes are few. Grinding tubs are absent at Piócási-dűlő as well, whereas at Polgár-Ferenci-hát they were fairly numerous. The inhabitants of the investigated part of the settlement sporadically produced polished stone or bone tools.

Another aspect of the behaviour of the inhabitants is reflected in the numerous traces of burning and perhaps of deliberate arson. The thoroughly burnt daub fragments recovered from the refuse pits are a clear indication of the one-time presence of wattle-and-daub buildings that had burnt down (or had perhaps been deliberately set on fire) both during the early and the late occupation period. The pre-conceived settlement renewal associated with house burning is reflected by the rapid infilling of some pits. It would appear that there was a periodic cessation of

fig. $26 ; 2$

\footnotetext{
${ }^{102}$ Starnini-SzaKmany 1998, fig. 12;1, 13;6, fig. 23;1,

${ }^{103}$ STARNINI 1994, fig. 44.
} 
activities in the area used for intensive domestic craft activities involving the spectacular closure of the area and its levelling (perhaps to make the area suitable for new activities).

Traces of burning can be interpreted as acts of ritual destruction of dwellings, which may correlate with destruction endowed with symbolic significance such as intentional breaking of stone artefacts, first of all grinding stones.

\section{ACKNOWLEDGMENTS}

The radiocarbon dates were obtained with the Obresoc project and with the help of Laboratoire de Mesure du Carbone 14, Saclay (Artemis), France. We are grateful to Jean-Francois Berger for his contribution. The study of lithics from Polgár-Piócási-dülő was sponsored by Research Project No 2085/B/H03/2011/40 of NCN (Polish National Research Centre), while the archaeobotanical study was financed by the Research Project No 2012/06/M/ HS3/00288 of NCN. Emese Gyöngyvér Nagy would here like to thank her colleague Zsigmond Hajdú for his valuable comments on the draught version of this paper. Thanks are due also to Panna Tolvaj for the drawings and to Viktória Czakó and Ákos Jurás for their help in preparing the illustrations.

\section{REFERENCES}

ASSMANN 1992

Asouti-Austin 2005

BADAL 1992

BÁNFFY-BOGNÁR-KUTZIÁN 2007

BARTHA et al. 1995

BEHRE 2008

BIENIEK 2002

BIENIEK 2007

BIRÓ 1998

BOGAARD 2004

BOGAARD 2005

BOGAARD et al. 2007

BognÁR-KuTZIÁN 1963

BogNÁR-KuTZIÁN 1972

BOHN-NEUHÄUSL 2004

BÖLÖNI et al. 2008
= J. Assmann: Das kulturelle Gedächtnis: Schrift, Erinnerung und politische Identität in frühen Hochkulturen. München 1992.

= E. Asouti-P. Austin: Reconstructing woodland vegetation and its exploitation by past societies, based on the analysis and interpretation of archaeological wood charcoal macro-remains. Environmental Archaeology 10 (2005) 1-18.

= E. BADAL: L'anthracologie préhistorique : à propos de certains problèmes méthodologiques. Bulletin de la Société Botanique de France 139 (1992) 167-189.

= E. BÁNFFY-I. BognÁR-KutziÁn: The Late Neolithic Tell Settlement at Polgár-Csőszhalom, Hungary. The 1957 Excavation. BAR IntSer 1730. Archaeolingua Central European Series 4. Oxford 2007.

= D. BARThA-B. KeveY-T. MorschHauser-T. Pócs: Hazai erdőtársulásaink [Forest associations in Hungary]. Tilia 1 (1995) 8-85.

= K.-E. BEHRE: Collected seeds and fruits from herbs as prehistoric food. Vegetation History and Archaeobotany 17 (2008) 65-73.

= A. BIENIEK: Archaeobotanical analysis of some early Neolithic settlements in the Kujawi region, with potential plant gathering activities emphasized. Vegetation History and Archaeobotany 11 (2002) 33-40.

= A. S. BIEnIEK: Neolithic plant husbandry in the Kujawy region of central Poland. In: S. Colledge-J. Conolly (eds): The Origins and Spread of Domestic Plants in Southwest Asia and Europe. University College London Institute of Archaeology publications. Walnut Creek 2007, 327-342.

$=$ K. T. BIRÓ: Lithic Implements and the Circulation of Raw Materials in the Great Hungarian Plain during the Late Neolithic Period. Budapest 1998.

= A. BogAARD: Neolithic Farming in Central Europe. London 2004.

= A. BOGAARD: "Garden agriculture" and the nature of early farming in Europe and the Near East. WA 37 (2005) 177-196.

= A BogaARD-J. BENDING-G. JonEs: Archaeobotanical evidence for plant husbandry and use at Ecsegfalva 23. In: A. Whittle (ed.): The Early Neolithic on the Great Hungarian Plain. Investigations of the Körös Culture Site of Ecsegfalva 23, County Békés. VAH 21. Budapest 2007, 421-445.

= I. BognÁR-KutziÁn: The Copper Age Cemetery of Tiszapolgár-Basatanya. ArchHung 42. Budapest 1963.

= I. BognáR-KutZiÁn: The Early Copper Age Tiszapolgár Culture in the Carpathian Basin. ArchHung 48. Budapest 1972.

= U. BohN-R. NeuHÄusL, with contributions by G. Gollub, C. Hettwer, Z. Neuhäuslová, Th. Raus, H. Schlüter, H. Weber: Map of the Natural Vegetation of Europe. Scale $1: 2500000$ (CD-ROM). Bonn 2004.

= J. BÖlÖNI-Zs. MolNÁR-M. BIRÓ-F. HoRvÁTH: Distribution of the (semi-) natural habitats in Hungary. II: Woodlands and shrublands. Acta Botanica Hungarica 50 (Suppl.) (2008) 107-148. 
BÖLÖNI et al. 2011

CAPPERs et al. 2006

CAPPERs et al. 2009

CARRIÓN 2005

Chabal 1988

Chabal 1992

Chabal 1997

Chapman 1999

ChapMan 2012

DANI-NAGY 2008

DOMBORÓCZKI 1997

DOMBORÓCZKY-RACZKY 2010

DOMBORÓCZKI et al. 2010

DONIŢA-KARAMYŠEVA 2004

DÖRTER 1968

ELLENBERG 1988

ESAU 1973

FALKOWSKI 1982

FÜZESI 2007

GARDNER 2002

GARDNER 2005

GILLINGS 2007

GLUZA et al. 1988

Gyulai 2007

GYULAI 2010
= J. BÖLÖNI-Z. BotTA-DuKÁT-E. ILlYÉS-Zs. MoLnÁR: Hungarian landscape types: classification of landscapes based on the relative cover of (semi-) natural habitats. Applied Vegetation Science 14 (2011) 537-546.

= R. T. J. CAPpers-R. M. BeKkeR-J. E. A. Jans: Digital Seed Atlas of the Netherlands. Groningen Archaeological Studies. Groningen 2006.

= R. T. J. CAPPERS-R. NEEF-R. M. BEKKER: Digital Atlas of Economic Plants. Part 1, 2a, 2b. Groningen Archaeological Studies. Groningen 2009.

= Y. CARRIóN: La vegetación mediterránea y atlántica de la Península Ibérica. Nuevas secuencias antracológicas. S.I.P. Trabajos varios 104. Valencia 2005.

$=$ L. CHABAL: Pourquoi et comment prélever les charbons de bois pour la période antique: les méthodes utilisées sur le site de Lattes (Hérault). Lattara 1 (1988) 187-222.

= L. CHABAL: La représentativité paléo-écologique des charbons de bois archéologiques issus du bois de feu. Bulletin de la Société Botanique de France 139 (1992) 213-236.

= L. Chabal: Forêts et sociétés en Languedoc (Néolithic final, Antiquité tardive). L'anthracologie, méthode et paléoécologie. Documents d'archéologie Française 63. Paris 1997.

= J. Chapman: Deliberate house-burning in the Prehistory of central and eastern Europe. In: A. Gustaffson-H. Karlsson (eds.): Glyfer och arkeologiska rum: En vänbok till Jarl Nordbladh. Gotarch series A3. Göteborg 1999, 113-116.

= J. CHAPMAN: Structured deposition meets deliberate object fragmentation. Archeological Dialogues 19 (2012) 129-133.

= J. DanI-E. Gy. NAGY: Polgár, Piócási-dűlő. In: J. Kisfaludi (ed.): Régészeti kutatások Magyarországon 2007 - Archeological Investigations in Hungary 2007. Budapest 2008, 261-264.

= L. Domboróczki: Füzesabony-Gubakút. Újkőkori falu a Kr.e. VI. évezredből. (Neolithic village from the $6^{\text {th }}$ Millennium B.C.) In: P. Raczky-T. Kovács-A. Anders (eds): Utak a múltba. Az M3-as autópálya régészeti leletmentései $=$ Paths into the Past. Rescue Excavations on the M3 Motorway. Budapest 1997, 19-25.

= L. DOMBOROCZKI-P. RACZKY: Excavations at Ibrány-Nagyerdö and the northernmost distribution of the Körös Culture in Hungary. In: J. K. Kozlowski-P. Raczky (eds): Neolithization of the Carpathian Basin: Northernmost Distribution of the Starčevo/Körös Culture. Kraków-Budapest 2010, 191-218.

= L. DomboróczKI-M. KacZanowsKA-J. K. KozŁowsKi: The Neolithic settlement of TiszaszőlősDomaháza-puszta and the question of the Northern spread of the Körös Culture. Atti Società de Preistoria e Protostoria Friuli-Venezia Giulia 17 (2010) 101-155.

= N. DoniţA-Z. V. KARAMYŠEVA, with contribution by A. Borhidi, U. Bohn: Forest steppes (Meadow steppes alternating with nemoral deciduous forests) and dry grasslands alternating with dry scrub. Map of the Natural Vegetation of Europe. Scale $1: 2500000$ (CD-ROM). In: BoHN-NEUHÄUSL 2004, 375-389.

= K. DÖRTER: Das Bestimmen der Samen von Gräsern and Schmetterlingsblütlern. Berlin 1968.

= H. Ellenberg: Vegetation Ecology of Central Europe. Cambridge-New York 1988.

$=$ K. ESAU: Anatomia roślin. Warszawa 1973.

= M. FALKOWSKI (ed.): Trawy polskie [Grasses in Poland]. Warszawa 1982.

= A. FüZESI: A neolit településszerkezet változásai a Felsö-Tisza-vidéken Polgár és Tiszacsege közötti terepbejárások alapján [Changes of Neolithic Settlement Structure in the Upper Tisza Region on the Basis of Field Walks between Polgár and Tiszacsege]. [MA Thesis, manuscript.] Eötvös Loránd University, Budapest 2007.

= A. R. GARDNER: Neolithic to Copper Age woodland impacts in northeast Hungary? Evidence from the pollen and sediment chemistry records. The Holocene 12 (2002) 541-553.

= A. R. GARDNER: Natural environment or human impact? A palaeoeocological study of two contrasting sites in North-Eastern Hungary In: E. Gál-I. Juhász-P. Sümegi (eds.): Environmental Archaeology in North-Eastern Hungary. VAH 19. Budapest 2005, 87-106.

= M. GILlings: The Ecsegfalva landscape: affordance and inhabitation. In: A. Whittle (ed.): The Early Neolithic on the Great Hungarian Plain. Investigtions of the Körös Culture Site of Ecsegfalva 23, County Békés. VAH 21. Budapest 2007, 31-46.

= I. GLUZA-Z. TOMCZYŃSKA-K. WASYLIKOWA: Uwagi o użytkowaniu drewna w neolicie na podstawie węgli drzewnych ze stanowisk archeologicznych w Krakowie-Nowej Hucie [Comments on the use of wood in the Neolithic on the basis of charcoal remains from archaeological sites in Krakow Nowa Huta]. MatArchNH 12 (1988) 7-25.

= F. GyUlaI: Seed and fruit remains associated with Neolithic origins in the Carpathian Basin. In: S. Colledge-J. Conolly (eds): The Origins and Spread of Domestic Plants in Southwest Asia and Europe. University College London Institute of Archaeology publications. Walnut Creek 2007, 125-139.

= F. GYULAI: Archaeobotanical research at the Körös culture site of Ibrány-Nagyerdő and its relationship to plant remains from contemporaneous sites in Hungary. In: J. K. Kozłowski-P. Raczky (eds.): 
GyULAI 2013

HAJDÚ 2007

HAJNALOVÁ 2007

\section{HARRINGTON 1995}

HeINZ-ThiÉBAUlt 1998

HEJNOWICZ 2002

JÁRAI-KOMLÓDI 1968

JÁRAI-KOMLÓDI 2003

JACOMET 2007

JUHÁSZ 2005

KACZANOWSKA-KOZŁOWSKI 2013

KALICZ-MAKKAY 1977

KALLA 2013

KAMINSKÁ et al. 2008

KOHLER-SCHNEIDER 2007

KowAL 1953

KOWAL-RUDNICKA-STERNOWA 1969

KoZŁowSKI 1989

KoZŁowsKi (ed.) 1997

KoZŁOWSKI 2001

KOZŁOWSKI-NowAK 2007

KREUZ 2007

KREUZ 2010/2012
Neolithization of the Carpathian Basin: Northernmost Distribution of the Starčevo/Körös Culture. Budapest-Kraków 2010, 219-237.

= F. GyUlaI: Archaeobotanical Research of the Neolithic sites in the Polgár area In: A. AndersG. Kulcsár (eds): Moments in Time. Papers Presented to Pál Raczky on His $60^{\text {th }}$ Birthday. Budapest 2013, 865-900.

= Zs. HAJDÚ: Rituális gödrök a Kárpát-medencében a Kr.e. 6000-3500 közötti időszakban [Ritual Pits in the Carpathian Basin between 6000-3500 BC]. [PhD Thesis, manuscript]. Eötvös Loránd University, Budapest 2007. http://doktori.btk.elte.hu/hist/hajduzsigmond/diss.pdf

= M. Hajnalová: Early farming in Slovakia: an archaeobotanical perspective. In: S. ColledgeJ. Conolly (eds): The Origins and Spread of Domestic Plants in Southwest Asia and Europe. University College London Institute of Archaeology publications. Walnut Creek 2007, 295-313.

= A. HARrington: Anthropogenic Impact upon the Eastern Hungarian Landscape. [MSc Thesis, manuscript]. Cambridge 1995.

= C. HeINZ-S. ThiÉBAult: Characterization and palaeoecological significance of archaeological assemblages during Late and Post-Glacial phases in Southern France. Quaternary Research 50 (1998) 56-68.

= Z. HEJNOwICZ: Anatomia i histogeneza roślin naczyniowych. Organy wegetatywne [Anatomy and Histogenesis of Vascular Plants. Vegetative Organs]. Warszawa 2002.

= M. JÁRAI-Komlódi: The Late Glacial and Holocene flora of the Hungarian Great Plains. AUB Sectio Biologica 9-10 (1968) 199-225.

= M. JÁRAI-KOMLÓdI: Quarternary Vegetation History in Hungary. Budapest 2003.

= S. JACOMET: Neolithic plant economies in the northern Foreland In: S. Colledge-J. Conolly (eds): The Origins and Spread of Domestic Plants in Southwest Asia and Europe. University College London Institute of Archaeology publications. Walnut Creek 2007, 221-258.

= I. JUHÁsz: Detecting anthropogenic impacts in the palaeobotanical samples from Csaroda-Nyíres-tó. In: E. Gál-I. Juhász-P. Sümegi (eds.): Environmetal Archaeology in North-Eastern Hungary. VAH 19. Budapest 2005, 55-66.

$=$ M. KaCZANOWSKA-J. K. KozŁowsKi: New approach to the formation of the Eastern Linear Culture in the Carpathian Basin. Rocznik PAU 2012-2013, 295-306.

= N. KaLICZ-J. MaKKaY: Die Linienbandkeramik in der Großen Ungarischen Tiefebene. StudArch 7. Budapest 1977.

= G. KALLA: A háztartások régészete mint kutatási probléma (Household archaeology as a research problem). In: M $\Omega$ MO $\Sigma$ VII - Őskoros Kutatók VII. Összejövetele, 2011. március 16-18. Százhalombatta, Matrica Múzeum. Ősrégészeti Levelek 13 (2011) [2013] 9-36.

= L. KaminskÁ-M. KacZanowsKa-J. K. KozŁowski: Košice-Červený rak and the Körös/Eastern Linear transition in the Hornád Basin (Eastern Slovakia). PV 49 (2008) 83-91.

= M. KoHLER-SCHNEIDER: Early agriculture and subsistence in Austria. In: S. Colledge-J. Conolly (eds): The Origins and Spread of Domestic Plants in Southwest Asia and Europe. University College London Institute of Archaeology publications. Walnut Creek 2007, 209-220.

$=$ T. KowAL: Klucz do oznaczania nasion rodzaju Chenopodium L. i Atriplex L [A key for the identification of seeds of the genera Chenopodium L. and Atriplex L.]. Monographiae Botanicae 1 (1953) 87-163.

$=$ T. KOWAL-W. RUDNICKA-STERnOwA: Morfologia i anatomia ziarniaków krajowych gatunków rodzaju Bromus L [Morphology and anatomy of the caryopses of species in the Bromus L. genus in Poland] Monographiae Botanicae 29 (1969) 1-68.

= J. K. KozŁowski: The lithic industry of the Eastern Linear Pottery Culture in Slovakia. S1A 37/2 (1989) 377-410.

= J. K. KozŁowsKi (ed): The Early Linear Pottery Culture in Eastern Slovakia. Polish Academy of Arts and Sciences, Prace Komisji Prehistorii Karpat 1. Kraków 1997.

= J. K. KozŁowsKI: Evolution of lithic industries of the Eastern Linear Pottery Culture. In: R. KertészJ. Makkay (eds): From the Mesolithic to the Neolithic. Proceedings of the International Archaeological Conference held in the Damjanich Museum of Szolnok, September 22-27, 1996. Archaeolingua 11. Budapest 2001, 247-260.

= J. K. KozŁowsKI-M. NowaK: Neolithization of the Upper Tisza basin. In: J. K. KozłowskiM. Nowak (eds): Mesolithic/Neolithic Interactions in the Balkans and in the Middle Danube Basin. BAR IntSer 1726. Oxford 2007, 77-102.

= A. KREUZ: Archaeobotanical perspectives on the beginning of agriculture north of the Alps. In: S. Colledge-J. Conolly (eds): The Origins and Spread of Domestic Plants in Southwest Asia and Europe. University College London Institute of Archaeology publications. Walnut Creek 2007, 259-294.

= A. KreUZ: Die Vertreibung aus dem Paradies? Archäobiologische Ergebnisse zum Frühneolithikum im westlichen Mitteleuropa. BRGK 91 (2010/2012) 23-196. 
KREUZ-SCHÄFER 2011

KuLPA 1974

LITYŃSKA-ZAJĄC 2005

LITYŃSKA-ZAJĄC 2007

LITYŃSKA-ZAJĄC-WASYLIKOWA 2005

LITYŃSKA-ZAJAC et al. 2008

LÜNING 1991

MAGYARI 2011

MAGYARI et al. 2001

MAGYARI et al. 2008

MAGYARI et al. 2010

MAGYARI et al. 2012

MAKKAY 1982

MARINOVA 2007

MateiciuCOVÁ 2007

MoLNÁR et al. 2012

MONAH 2007

MosKAL-DEL Hoyo 2013

NowAK et al. 2010

NTINOU 2002

Pearsall 2000

PÉCSI-SÁRFALVI 1964

PÉCSI et al. 1989

PotUSHNIAK 2011

RACZKY 2004

RACZKY-ANDERS 2009
= A. KREUZ-E. SCHÄFER: Weed finds as indicators for the cultivation regime of the early Neolithic Bandkeramik culture? Vegetation History and Archaeobotany 20:5 (2011) 333-348.

= W. KULPA: Nasionoznawstwo chwastów [Carpology of the Weeds]. Warszawa 1974.

= M. LiTYŃSKA-ZAJĄC: Chwasty w uprawach roślinnych w pradziejach i wczesnym średniowieczu [Segetal Weeds in Prehistoric and Early Medieval Crop Cultivation]. Kraków 2005.

= M. LiTYŃSKA-ZAJĄC: Early Neolithic agriculture in south Poland as reconstructed from archaeobotanical plant remains In: S. Colledge-J. Conolly (eds): The Origins and Spread of Domestic Plants in Southwest Asia and Europe. University College London Institute of Archaeology publications. Walnut Creek 2007, 315-326.

= M. LitYŃSKA-ZAJĄC-K. WASYLIKOWA: Przewodnik do badań archeobotanicznych [Guide to Archaeobotanical Research]. Vademecum geobotanicum. Poznań 2005.

= M. LityńsKa-Zając-M. Moskal-Del Hoyo-M. NowaK: Plant remains from Early Neolithic settlement at Moravany (Eastern Slovakia). Vegetation History and Archaeobotany 17 (2008) 81-92.

= J. LÜNNING: Frühe Bauern in Mitteleuropa im 6. und 5. Jahrtausend v. Chr. JRGZM 35 (1991) 27-93.

= E. MAGYARI: Late Quaternary vegetation history in the Hortobágy steppe and Middle Tisza floodplain, NE Hungary. Studia Botanica Hungarica 42 (2011) 185-203.

= E. K. Magyari-P. Sümegi-M. Braun-G. JaKab-M. Molnár: Retarded wetlands succession: anthropogenic and climatic signals in a Holocene peat profile from north-east Hungary. Journal of Ecology 89 (2001) 1019-1032.

= E. K. MAGYARI-G. JAKAB-P. SÜMEGI: Holocene vegetation dynamics in the Bereg Plain, NE Hungary - the Báb-tava pollen and plant macrofossil record. Acta GGM Debrecina: Geology, Geomorphology, Physical Geography Series 3 (2008) 33-50.

= E. K. Magyari-J. C. Chapman-D. G. Passmore-J. R. M. Allen-J. P. Huntley-B. Huntley: Holocene persistence of wooded steppe in the Great Hungarian Plain. Journal of Biogeography 37 (2010) 915-935.

= E. K. Magyari-J. C. Chapman-A. S. Fairbairn-M. Francis-M. De Guzman: Neolithic human impact on the landscapes of North-East Hungary inferred from pollen and settlement records. Vegetation History and Archaeobotany 21 (2012) 279-302.

= J. MAKKAY: A magyarországi neolitikum kutatásának új eredményei. Az időrend és a népi azonosítás kérdései [New Results in Neolithic Research from Hungary. Questions of chronology and ethnic identification ]. Budapest 1982.

$=$ E. Marinova: Archaeobotanical data from the early Neolithic of Bulgaria. In: S. Colledge-J. Conolly (eds): The Origins and Spread of Domestic Plants in Southwest Asia and Europe. University College London Institute of Archaeology publications. Walnut Creek 2007, 93-109.

= I. Mateiciucová: Worked stone: obsidian and flint. In: A. Whittle (ed.): The Early Neolithic on the Great Hungarian Plain. Investigations of the Körös Culture Site of Ecsegfalva 23, County Békés. VAH 21. Budapest 2007, 667-720.

= Zs. MolnÁR-M. Biró-S. BARTHA-G. FeKETE: Past trends, present state and future prospects of Hungarian forest-steppes. In: M. J. A. Werger-M. A. van Staalduinen (eds): Eurasian Steppes. Ecological Problems and Livelihoods in a Changing World. Plant and vegetation 6. Dordrecht 2012, 209-252.

= F. MonAH: The spread of cultivated plants between the Carpathians and Dniester. In: S. ColledgeJ. Conolly (eds): The Origins and Spread of Domestic Plants in Southwest Asia and Europe. University College London Institute of Archaeology publications. Walnut Creek 2007, 111-123.

= M. MoskaL-Del Hoyo: Mid-Holocene forests from Eastern Hungary: new anthracological data. Review of Palaeobotany and Palynology 193 (2013) 71-80.

= M. NowaK-J. K. KozlowsKi-M. KaCZANOWSKA-M. VizdAL-T. KALICKI-M. MosKal-Del HoyoA. Budek-G. Litvinyuk-M. LityńsKa-ZajĄc-E. Sobierska-P. Wyszomirski: Early Neolithic in the Upper Tisza Basin: new data from Moravany, Eastern Slovakia. Eurasian Prehistory 7:1 (2010) 159-219.

= M. NTinou: La Paleovegetación en el Norte de Grecia desde el Tardiglaciar hasta el Atlántico. Formaciones vegetales, recursos y usos. BAR IntSer 1083. Oxford 2002.

= D. M. Pearsall: Palaeobotany. A handbook of Procedures. San Diego 2000.

= M. PÉCSI-B. SÁRFALVI: Geography of Hungary. London 1964.

= M. PÉcsi-L. Bassa-P. Beluszky-I. Berényi-A. BoraI-L. Füsy-Z. Keresztesi-A. Kota-S. MAROSI-A. PAPP-VÁRY-J. SZILÁDI-S. SZŐKE-TASI (eds): Magyarország nemzeti atlasza (National Atlas of Hungary). Budapest 1989.

= M. PotushniaK: Neolithic Settlement at Drisino-Balocza, Transcarpathian Ukraine. Kraków 2011.

= P. RACZKY: Polgár, Ferenci-hát. In: J. Kisfaludi (ed.): Régészeti kutatások Magyarországon 2002 - Archeological Investigations in Hungary 2002. Budapest, 257-258.

$=$ P. RACZKY-A. ANDERS: Settlement history of the Middle Neolithic in the Polgár Micro-Region (The development of the Alföld Linearband Pottery in the Upper Tisza Region, Hungary). In: J. K. 
RACZKY-ANDERS 2012

RACZKY et al. 1994

RACZKY et al. 2007

RACZKY et al. 2011

RACZKY et al. 2012

ROBERTS 1998

RYMKIEWICZ 1979

SCHWEINGRUBER 1982

SCHWEINGRUBER 1990

SENETA-DOLATOWSKI 2004

STARKEL 1988

Soó 1964

Soó 1966

STARNINI 1994

STARNINI-SZAKMÁNY 1998

SÜMEGI 1999

SÜMEGI 2003

SÜMEGI 2013

SÜMEGI-MOLNÁR 2007

SÜMEGI et al. 2005

SZEVERÉNYI 2013
Kozłowski (ed.): Interactions between Different Models of Neolithization North of the Central European Agro-Ecological Barrier. Polish Academy of Arts and Sciences, Prace Komisji Prehistorii Karpat 5. Kraków 2009, 31-50.

= P. RACZKY-A. ANDERs: Neolithic enclosures in Eastern Hungary and their survival into the Copper Age. In: F. Bertemes-H. Meller (Hrsg.): Neolitische Kreisgrabenanlagen in Europa / Neolithic Circular Enclosures in Europe. Internationale Arbeitstagung 7.-9. Mai 2004 in Goseck (SachsenAnhalt) / International Workshop $7^{\text {th }}-9^{\text {th }}$ May in Goseck (Saxony-Anhalt, Germany). Tagungen des Landesmuseums für Vorgeschichte Halle 8. Halle (Saale) 2012, 271-309.

= P. Raczky-W. Meier-Arendt-K. Kurucz-Zs. Hajdú-Á. Szikora: Polgár-Csőszhalom. A Late Neolithic settlement in the Upper Tisza Region and its cultural connections (Preliminary report). JAMÉ 36 (1994) 231-240.

= P. RACZKY-L. DOMBORÓCZKI-Zs. HAJdú: The site of Polgár-Csőszhalom and its cultural and chronological connections with the Lengyel culture. In: J. K. Kozłowski-P. Raczky (eds): The Lengyel, Polgár, and Related Cultures in the Middle/Late Neolithic in Central Europe. Kraków 2007, 49-70.

= P. RACZKY-A. ANDERS-L. BARTOSIEWICZ: The enclosure system of Polgár-Csőszhalom and its interpretation. In: S. Hansen-J. Müller (Hrsg.): Sozialarchäologische Perspektiven: Gesellschaftlicher Wandel 5000-1500 v. Chr. zwischen Atlantik und Kaukasus. Archäologie in Eurasien 24. Darmstadt 2011, 57-59.

= P. RACZKY-P. SÜMEgi-L. BartosiewicZ-E. GÁL-M. KacZanowsKa-J. K. KozŁowsKi-A. Anders: Ecological barrier versus mental marginal zone? Problems of the northernmost Körös Culture settlements in the Great Hungarian Plain. In: D. Gronenborn-J. Petrasch (eds): The Neolitisierung Mitteleuropas - The Spread of the Neolithic to Central Europe. Mainz 2012, 147-173.

= N. RoberTs: The Holocene. An Environmental History. Oxford 1998.

= A. Rymkiewicz: Badania nad gatunkami z rodzaju Plantago L. z uwzględnieniem karpologii i chemotaksonomii [Studies on the species of the genus Plantago L. with reference to carpology and chemotaxonomy]. Monographiae Botanicae 57 (1979) 71-103.

= F. H. SchweIngruber: Mikroskopische Holzanatomie. Teufen 1982.

= F. H. SchweINGRUBER: Anatomie europäischer Hölzer. Bern-Stuttgart 1990.

= W. SEnETA-J. Dolatowski: Dendrologia. Warszawa 2004.

= L. StARKel: Rzeźba. In: J. Warszyńska (ed.): Województwo Tarnowskie [Tarnów Voivodeship]. Wrocław 1988, 19-28.

= R. Soó: Magyar flóra és vegetáció rendszertani-növényföldrajzi kézikönyve I. Synopsis systematico-geobotanica florae vegetationisque Hungariae I. Budapest 1964.

= R. SoÓ: Magyar flóra és vegetáció rendszertani-növényföldrajzi kézikönyve II. Synopsis systematico-geobotanica florae vegetationisque Hungariae II. Budapest 1966.

= E. STARnini: Typological and technological analyses of the Körös culture chipped, polished and ground stone assemblages of Méhtelek-Nádas (North-eastern Hungary). Atti della Società per la Preistoria e Protostoria della Regione Friuli-Venezia Giulia 8 (1993) 29-96.

= E. StARnini-Gy. SZAKMÁNy: The lithic industry of the Neolithic sites of Szarvas and Endröd (Southeastern Hungary): techno-typological and archaeometrical aspects. ActaArchHung 50 (1998) 279-342.

= P. SüMEGI: Reconstruction of flora, soil and landscape evolution, and human impact on the Bereg Plain from Late-Glacial to the present, based on paleoecological analysis. In: J. Hamar-A. SárkányKiss (eds): The Upper Tisa Valley. Szeged 1999, 171-203.

= P. SÜMEGI: Jelentés a Polgár-Ferenci-hát régészeti lelőhely régészeti geológiai feldolgozásáról [Report on geological analyses at the archaeological site of Polgár-Ferenci-hát]. Szeged 2003. (Déri Múzeum Régészeti Adattára: 579)

= P. SüMEGI: The geoarchaeological evolution of the loess-covered alluvial island of Polgár and its role in shaping human settlement strategies. In: A. Anders-G. Kulcsár (eds): Moments in Time. Papers Presented to Pál Raczky on His $60^{\text {th }}$ Birthday. Budapest 2013, 901-912.

= P. SüMEGI-S. MolnÁR: The Kiri-tómeander: sediments and the questions of floods. In: A. Whittle (ed.): The Early Neolithic on the Great Hungarian Plain. Investigations of the Körös Culture Site of Ecsegfalva 23, County Békés. VAH 21. Budapest, 67-82.

= P. SÜMEGI-B. CsÖKMEI-G. Persaits: The evolution of Polgár Island a loess-covered lag surface and its influences on the subsistence of settling human cultural groups. In: L. Hum-S. Gulyás-P. Sümegi (eds): Environmental Historical Studies from the Late Tertiary and Quaternary of Hungary. Szeged 2005, 141-164

= V. SZEVERÉNYI: Bronzkori „háztűznéző”: szándékos házégetés és anyagi metaforák a Kárpát-medence kora és középső bronzkorában (Deliberate house-burning and material metaphors in the Early and Middle Bronze Age of the Carpathian Basin). In: M $\Omega$ MO $\Sigma$ VII - Öskoros Kutatók VII. Összejövetele, 2011. március 16-18. Százhalombatta, Matrica Múzeum. Ősrégészeti Levelek 13 (2011) [2013] 215-232. 
THÉRY-PARISOT 2001

TURNER 2002

VAN GENNEP 2007

WhITTLE et al. 2013

WILLIS 2007

WILLIS et al. 1995

WILLIS et al. 1998

ZALAI-GAÁL 1988

ZÓLYOMI-FEKETE 1994
= I. THÉRY-PARISOT: Economie des combustibles au Paléolithique. Expérimentation, anthracologie, taphonomie. Dossiers de documentation archéologique 20. Paris 2001.

= V. TuRNER: A rituális folyamat. Struktúra és antistruktúra (The Ritual Process: Structure and Antistructure.). Budapest 2002.

= A. VAN GENNEP: Átmeneti rítusok (The Rites of Passages). Budapest 2007.

= A. Whittle-A. Anders-A. Bentley-P. Bickle-L. Cramp-L. DomborócZKi-Z. Guba-L. FibigerJ. Hamilton-R. Hedges-N. Kalicz-T. Marton-K. Oross-P. Raczky: Hungary. In: The First Farmers in Central Europe: Diversity in LBK Lifeways. Oxford 2013.

$=$ K. J. WiLlis: The impact of the early Neolithic Körös Culture on the landscape: evidence from palaeoecological investigations of the Kiri-tó In: A. Whittle (ed.): The Early Neolithic on the Great Hungarian Plain. Investigtions of the Körös Culture Site of Ecsegfalva 23, County Békés. VAH 21. Budapest 2007, 83-98.

= K. J. Willis-P. SüMEGI-M. BRAUN-A. TóTH: The Late Quaternary environmental history of Bátorliget, NE. Hungary. Palaeogeography, Palaeoclimatology, Palaeoecology 118 (1995) 25-47.

= K. J. Willis-P. SüMegi-M. Braun-K. D. BennetT-A. Tóth: Prehistoric land degradation in Hungary: who, how and why? Antiquity 72 (1998) 101-113.

= I. ZALAI-GAÁL: Közép-európai neolitikus temetők szociálarchaeológiai elemzése (Sozialarchäologische Untersuchungen des mitteleuropäischen Neolithikums aufgrund der Gräberfeldanalyse). BÁMÉ 14 (1988) 3-178

= B. Zólyomi-G. Fekete: The Pannonian loess steppe: differentiation in space and time. Abstracta Botanica 18 (1994) 29-41. 